NBER WORKING PAPER SERIES

\title{
DOES ECONOMICS MAKE YOU SEXIST?
}

\author{
Valentina A. Paredes \\ M. Daniele Paserman \\ Francisco Pino \\ Working Paper 27070 \\ http://www.nber.org/papers/w27070 \\ NATIONAL BUREAU OF ECONOMIC RESEARCH \\ 1050 Massachusetts Avenue \\ Cambridge, MA 02138 \\ May 2020
}

We thank Leah Boustan, Damian Clarke, Stefano DellaVigna, Shoshana Grossbard, Pablo Guzmán-Pinto, Daniel Hamermesh, Shulamit Kahn, Shelly Lundberg, Patricia Funk, and participants at the American Economic Association Annual Meetings, the WERISE Women in Economics Conference and seminar participants at Boston University, Universidad de Chile, PUC-Chile, Universitat de Barcelona, Universidad Carlos III de Madrid, CU Denver and Duke University for helpful comments. Gerard Domènech, Juan Luis Fuentes, Danilo Kuzmanic and Daniela Paz provided excellent research assistance. The authors gratefully acknowledge funding from Fondecyt Inicio, Project 11170968, the Centre for Social Conflict and Cohesion Studies (CONICYT/FONDAP/15130009) and the Millennium Nucleus of Social Development, supported by the Millennium Scientific Initiative of the Ministry of Economy, Development and Tourism (Chile). This research was approved by the University of Chile Institutional Review Board. The usual disclaimers apply. The views expressed herein are those of the authors and do not necessarily reflect the views of the National Bureau of Economic Research.

NBER working papers are circulated for discussion and comment purposes. They have not been peer-reviewed or been subject to the review by the NBER Board of Directors that accompanies official NBER publications.

(C) 2020 by Valentina A. Paredes, M. Daniele Paserman, and Francisco Pino. All rights reserved. Short sections of text, not to exceed two paragraphs, may be quoted without explicit permission provided that full credit, including $(\odot$ notice, is given to the source. 
Does Economics Make You Sexist?

Valentina A. Paredes, M. Daniele Paserman, and Francisco Pino

NBER Working Paper No. 27070

May 2020

JEL No. A13,A14,A22,J16,J71

\begin{abstract} Exposure to female students and faculty attenuates some of the bias.

Valentina A. Paredes

Department of Economics

University of Chile

Diagonal Paraguay 257

Of. 1305A Santiago

Chile

vparedes@fen.uchile.cl

M. Daniele Paserman

Department of Economics

Boston University

270 Bay State Road

Boston, MA 02215

and NBER

paserman@bu.edu

Francisco Pino

Department of Economics

University of Chile

Diagonal Paraguay 257

Of. 1505B

Santiago

Chile

fjpino@fen.uchile.cl
\end{abstract}

Recent research has highlighted unequal treatment for women in academic economics along several different dimensions, including promotion, hiring, credit for co-authorship, and standards for publication in professional journals. Can the source of these differences lie in biases against women that are pervasive in the discipline, even among students in the earliest stages of their training? In this paper, we provide evidence on the importance of explicit and implicit biases against women among students in economics relative to other fields. We conducted a large scale survey among undergraduate students in Chilean universities, among both entering first-year students and students in years 2 and above. On a wide battery of measures, economics students are more biased than students in other fields. Economics students are somewhat more biased already upon entry, before exposure to any economics classes. The gap is more pronounced among students in years 2 and above, in particular for male students. We also find an increase in bias in a sample of students that we follow longitudinally. Differences in political ideology explain essentially all the gap at entry, but none of the increase in the gap with exposure.

A randomized controlled trials registry entry is available at https://www.socialscienceregistry.org/trials/5715 
If women have a comparative advantage over men in the household sector when they make the same investments in human capital, an efficient household with both sexes would allocate the time of women mainly to the household sector and the time of men mainly to the market sector.

— Gary Becker, A Treatise on the Family (1991 [1981])

\section{Introduction}

Economics is a difficult field for women. Despite substantial progress in women's educational attainment over the past 30 years, the fraction of women in economics, at all stages of the educational and professional ladder, has remained stubbornly low (Bayer and Rouse, 2016; Lundberg, 2018; Lundberg and Stearns, 2019). The underrepresentation of women may hurt the discipline, by constraining the types of questions that are asked, and by providing analyses that fail to take into account the full range of perspectives on specific issues. Moreover, economists have an outsize influence of on the public conversation (Wolfers, 2015). Therefore, female underrepresentation may also affect the types of policies that are publicly debated, and the implementation of policies that are ultimately enacted.

Recent research has highlighted unequal treatment of women in academic economics, along several different dimensions. Women in economics are less likely to be promoted, even conditional on productivity (Ginther and Kahn, 2004, 2014); male economists are less likely, relative to other fields, to exhibit a women preference in a hypothetical hiring scenario (Williams and Ceci, 2015); women receive less credit for co-authorship (Sarsons, 2017); female-authored papers in top economics journals are held to higher standards and go through a longer process of peer review (Hengel, 2017; Card, DellaVigna, Funk, and Iriberri, 2020); female instructors in economics receive lower teacher evaluations (Boring, 2017; Mengel, Sauermann, and Zölitz, 2019); women are underrepresented in principles of economics textbooks (Stevenson and Zlotnik, 2018); and women face explicit hostility in an anonymous online forum with academic and professional purposes (Wu, 2018). ${ }^{1}$

Does the unequal treatment of women in economics arise because of a pervasive bias against women that is present in the discipline, even among students in the earliest stages

\footnotetext{
${ }^{1}$ Although several studies have documented the unequal treatment of women in academic economics, there are other studies that find no evidence of unequal treatment. See for example Hamermesh and Schmidt (2003) and Donald and Hamermesh (2006).
} 
of their training? And, if economics is sexist, is it because it attracts individuals who are ex ante more sexist, or does economic training contribute to gender bias?

There can be a number of explanations for why gender bias is prevalent in economics. First, if economics is perceived as a relatively high paying field (Zafar, 2013), it may attract individuals with more traditional gender norms, especially among males. But it is also possible that exposure to economics itself leads to more gender bias. Economics students may encounter a small number of female faculty members relative to other fields. Exposure to female role models has been shown to lower the gender gap in major choice (Porter and Serra, forthcoming), and may also affect the degree of gender bias. Alternatively, it may be that the relatively low share of women among economics students facilitates the development of gender bias.

It may also be that economics training leads students to develop more market-oriented views about economic policy and, consequently, to identify more with the right on the political spectrum. This could lead to more gender bias among economics students if rightwing ideology on economic issues is also associated with a more conservative position on social and gender-related issues (Hammock, Routon, and Walker, 2016).

Finally, it is possible that the discipline of economics itself is responsible for the gap. As a social science, economics can potentially affect people's view of society, including the role of women. Some common economic theories, taken in their most simplistic version, could lead to more gender-biased views. For example, if markets are competitive and workers are paid their marginal product, the gender wage gap must reflect only differences in productivity between male and female workers. And, at least according to some theories, taste-based labor market discrimination cannot exist in the long run because it will be weeded out by competitive forces (Becker, 1971). ${ }^{2}$ An additional example is the theory of comparative advantage: applied to the household sphere, it can be used to justify traditional gender roles, as the opening quote illustrates. ${ }^{3}$

\footnotetext{
${ }^{2}$ Becker himself did not subscribe to such a simplistic view. In a 1968 article, he wrote:

"A few of the more extreme nineteenth-century advocates of a competitive market economy believed that eventually its extension and development would eliminate most economic discrimination... . Unfortunately, this has not yet taken place; discrimination exists, and at times even flourishes, in competitive economies. The position of Negroes in the United States being a clear example." (Becker, 1968).

${ }^{3}$ Throughout the paper, we will use the terms "sexism," "gender bias" and "traditional gender attitudes" interchangeably. This is done mostly for convenience. However, this use does not imply a normative
} 
In this paper, we provide direct evidence on the importance of explicit and implicit biases against women among students in economics relative to other fields. We conducted a large scale survey among undergraduate students in Chilean universities. As in many other countries, students in Chile choose jointly a college-major pair, and are enrolled in a specific major from the very first day they enter college. This allows us to separate selfselection from training, because we can identify economics students even before they have been exposed to any economics classes.

We collected data on 3,344 students concentrated in 7 universities in Chile: close to 1,800 first-year students, surveyed in January-March 2017 and March 2018; and about 1,500 upperclassmen, surveyed in August 2017. ${ }^{4}$ In addition, we were able to follow up a sample of the first year students between October 2018 and May 2019, when they were enrolled in their second year in college. We end up with a longitudinal sample of 379 students, and a total of 3,723 completed surveys.

We measured implicit bias using the gender-career and gender-science versions of the Implicit Association Test (IAT, Greenwald, McGhee, and Schwartz, 1998). We then administered a shortened version of the Ambivalent Sexism Inventory (ASI, Glick and Fiske, 1996) to measure both hostile and benevolent sexism. We also asked students a battery of questions on gender attitudes (similar to those asked in the World Values Survey), and beliefs about gender differences in mathematical ability. Finally, we asked students to assess the importance of various factors (including discrimination and differences in preferences and skills) for explaining the gender pay gap.

From these questions, we constructed nine different measures of gender bias: four of the measures were constructed following the guidelines in the literature (the two IAT scores and the benevolent and hostile sexism scores based on the ASI); the remaining ones were obtained by grouping survey questions into five clusters based on cluster latent variable analysis (Vigneau and Qannari, 2003). Finally, we used factor analysis to extract the first principal component of these nine measures and construct an aggregate measure of gender bias. As a validity test, we show that on almost all measures women appear to be substantially less gender-biased than men.

judgment. In fact, reasonable people can disagree as to whether the opening quote reflects gender bias or is a simple mathematical statement in which the conclusion follows logically from the assumptions.

${ }^{4}$ Throughout the paper we use the terms "upperclassmen" or "upperclass students" to refer to students in year 2 and above. 
We document that, on the vast majority of these measures, as well as on the aggregate gender-bias score, economics students are more biased than students in other fields. The gap between economics and non-economics students is about one third as large as the gap between men and women. There is some evidence that economics first-years are more biased already upon entry, before exposure to any economic classes. The gap becomes substantially more pronounced among upperclass students, in particular for male students. In our preferred specification, the difference-in-differences estimate of the effect of economics training on gender bias is about 0.09 standard deviations for the sample as a whole, and 0.18 standard deviations for male students.

Although we find evidence of differences in some observable predetermined characteristics between first-year and upperclass students, these differences are remarkably similar across fields, making it unlikely that the results are driven by differential selection of students into economics across different cohorts. Moreover, in the sample of students that we can follow longitudinally, we find evidence of an increase in bias of similar magnitude to the one found in the between-cohort analysis, in contrast to the notion that the results are driven by differential selection on unobservable characteristics. The combined evidence strongly suggests that exposure to economics causally leads to more gender-biased views. We also implement an IV analysis to address the concern that the results may be driven by economics students being more prone to become more gender-biased as they progress through their studies, but do not find much evidence in support of this view.

We next move to the analysis of possible mediating mechanisms. Students who are more religious and self-identify with the political right are more likely to choose economics relative to other fields (Hammock, Routon, and Walker, 2016). Consequently, political ideology and religiosity explain essentially all the gap in bias between economics and noneconomics students at the point of entry in college. However, the differences-in-differences estimates are essentially unaffected by controlling for political ideology or religiosity. Hence, these variables cannot explain away the increase in the gap between the freshman and later years. We find some evidence for a mediating role of exposure to female peers and professors: the increase in bias is smaller for economics students who had a large share of female peers and took classes with many female professors.

This paper is related to various strands of the literature. First, it connects to the growing literature showing unequal treatment of women in economics, even relative to other 
academic disciplines. Ginther and Kahn (2014) show that the gender gap in the probability of achieving tenure is $20 \%$ for economists, while the gender gap in other social sciences is $12 \%$. The same can be observed when studying the gender gap in the probability of promotion: while it is $50 \%$ for economists, it is only $25 \%$ for other social sciences. Ceci, Ginther, Kahn, and Williams (2015) study the gender gaps for women in different academic fields. Their results show that, once that they control for productivity, the gender gap in the probability of tenure disappears for all disciplines except for economics. Williams and Ceci (2015) conducted an experiment on more than 800 tenure-track faculty in biology, engineering, economics and psychology. In the experiment, faculty had to evaluate summaries describing hypothetical applicants to an assistant professor opening, where the gender of the applicant was manipulated. Their results show that both male and female faculty had a 2:1 preference for female applicants in all fields, with the only exception of male faculty in economics, who showed no gender preference. Sarsons (2017) finds that women in economics become less likely to receive tenure the more they coauthor, but there is no difference for men when they coauthor or solo-author. She attributes her results to the fact that, because coauthored papers do not provide information about the specific contribution of each individual, this leads to differential attribution of credit based on gender. Hengel (2017) finds that women's writing is held to higher standards in academic peer review, and as a result, female-authored papers in two top general-interest journals in economics spend longer in peer review. Card, DellaVigna, Funk, and Iriberri (2020) use data on referee recommendations and editorial decisions from four leading journals and find that referees of both genders appear to set a higher bar for female-authored papers. Grossbard, Yilmazer, and Zhang (2018) also find that female-authored papers in demographic economics receive more citations. Two recent papers analyze gender differences in acceptance rates to economics conferences. While Chari and Goldsmith-Pinkham (2017) find no significant differences for NBER Summer Institute conferences, Hospido and Sanz (2019) find a significant gap for conferences in Europe. Boring (2017) and Mengel, Sauermann, and Zölitz (2019) both find evidence of female instructors receiving lower teaching evaluations (in a French and Dutch university, respectively), despite the fact that student performance on final tests is not affected by instructor gender. Finally, Dupas, Modestino, Niederle, and Wolfers (2020) find that female economists face more (and more hostile) questions in professional seminars. ${ }^{5}$

\footnotetext{
${ }^{5}$ A recent survey of the literature can be found in Lundberg (2020).
} 
A number of previous papers have documented a gender gap in the propensity to study economics already at the undergraduate level. Dynan and Rouse (1997) and Emerson, McGoldrick, and Mumford (2012) find that women are less likely to major in economics, even after controlling for math aptitude, and other factors. Goldin (2015) documents that women are dissuaded from majoring in economics by poor performance in introductory courses, while males major in economics almost without regard to their grades.

Some studies have looked at the the difference between economics students and students in other fields. Frank, Gilovich, and Regan (1993) study the difference in levels of cooperation between economists and individuals in other fields, under the hypothesis that the models taught in economics promote lower levels of cooperation. A more recent example is Rubinstein (2006), where students have to decide whether to maximize profits by laying off half of a company's workforce, or have lower profits by firing less than that number. He finds that economics students had a much stronger tendency to maximize profits compared to students in law, mathematics, philosophy and business administration. Exposure to economics education also has real consequences: Ash, Chen, and Naidu (2019) find that federal judges who participated in an economics training program were more likely to render conservative verdicts in economics cases, rule against regulatory or taxation agencies, and impose longer criminal sentences.

Our research is also related to the literature that analyzes the effects of selection compared to the effects of group socialization and/or training. The selection effect is driven by self-selection (individuals select environments that fit their values and ideologies) and institutional selection (institutions recruit people that match their values and ideologies), as described in Haley and Sidanius (2005). On the other hand, group socialization leads individuals to share and internalize specific values, norms and social knowledge. For example, Gatto, Dambrun, Kerbrat, and De Oliveira (2010) found that both selection and group socialization could explain police officers' prejudice towards disadvantaged groups. Frank, Gilovich, and Regan (1993) show evidence that the lower cooperation rates found for economic majors are due in part to economic training, since they find that the difference in cooperation rates between economic and non-economic majors increases between freshman and senior years. However, Carter and Irons (1991) found evidence that lower levels of cooperation among economists are associated with self-selection into the economics major. Their results are mixed as to whether the difference between economists and non-economic 
students persists between freshmen and senior years, but they find no evidence that the initial difference widens with economic training.

Finally, we believe that our paper can also inform the debate about the emergence of populist parties and movements around the world. Several of these parties have drawn disproportionate support from men (Norris, 2005 and Inglehart and Norris, 2016), in part by appealing to male economic insecurities generated by the forces of globalization and deindustrialization. Inglehart and Norris (2016) hypothesize that the displacement of traditional patriarchal values about fixed sex roles may have generated resentment, anger and a sense of loss among older and less educated individuals. This in turn may have led to an increase in support for populist right wing parties (which tend to share a combination of patriarchal family values and antifeminism, Mudde, 2007) in particular among older and less educated male voters. This paper, even though it is focused on the economics profession, can shed some light on the factors that contribute to the emergence of these sentiments in the broader population.

Most closely related to our work is the paper by Hammock, Routon, and Walker (2016) which uses longitudinal data on undergraduates in U.S. colleges and universities and examines how majoring in economics affects student opinions on a variety of social, political and economic issues. Studying economics appeared to increase beliefs in favor of personal freedom and decrease support for government intervention in markets. One question asked students to evaluate the statement that married women's activities "are best confined to the home and family." The paper finds no difference in responses to this question between economics and non-economics majors, either at matriculation or at graduation. Our paper extends this analysis by asking a much wider battery of questions on gender bias, which allows us to investigate whether economics training affects gender attitudes along a variety of different dimensions.

The rest of the paper is organized as follows. Section 2 gives the background, describing recent trends in gender inequality in Chile, the Chilean university system, Economics in Chile and women and higher education. Section 3 describes the survey, while section 4 reports our main results. In section 5 we explore possible mechanisms. Finally, section 6 concludes. 


\section{Background}

\subsection{Gender inequality in Chile}

Chile is the second richest economy in Latin America, with a GDP per capita of $\$ 15,346$ (current US dollars). It is a member of the OECD since 2010. Since 1990, the GDP per capita has increased at an average rate of about $7 \%$ per year. This economic success has been accompanied by a reduction in the poverty rate from $39 \%$ in 1990 to $12 \%$ in 2015, and an increase in life expectancy from 74 to 79 in those same years. ${ }^{6,7}$ However, despite these improvements in economic and social outcomes, the country still exhibits significant gender inequality. Female labor force participation, despite increasing from 32\% in 1990 to $51 \%$ in 2017, is still below the average for South America (55\%). ${ }^{8}$ The raw gender gap in monthly wages is $31.7 \%$. Even among full-time employees, the gender gap in hourly wages is $19.4 \%$. The United Nations Gender Inequality Index ranks Chile $65^{\text {th }}$ out of 188 countries (the U.S. is ranked 43), while the World Economics Forum Gender Gap Index ranks Chile $63^{\text {rd }}$ of 144, and only $117^{\text {th }}$ in the Economic Participation and Opportunity subcategory.

To further compare the gender attitudes of the Chilean population to gender attitudes in other countries, we use the 2016 World Values Survey and construct two variables that take the value of 1 if the respondent agrees or strongly agrees with the following statements: "When mother works for pay, the children suffer", and "When jobs are scarce, men should have more right to a job than women". ${ }^{9}$ Figure 1 shows the percentage of the population under 25 years old that agrees or strongly agrees with the statements by countries. ${ }^{10}$ About $27 \%$ of respondents agree with the first statement in Chile, somewhat below the OECD average, but slightly higher than in the U.S. The fraction agreeing with the second statement is about $10 \%$ in Chile, again somewhere in between the U.S. and the OECD average. On the whole, Chilean young adults appear to have somewhat more traditional views about gender roles than their U.S. counterparts, but the differences are not very large.

\footnotetext{
${ }^{6}$ Source: World Bank data: https://data.worldbank.org/country/chile.

${ }^{7}$ Starting in October 2019, Chile has been rocked by a series of violent protests. The protests began as a response to an increase in subway fares in Santiago, and soon extended to all other major cities, and took on the character of a general protest against social and economic inequality. These protests took place after completion of our data collection.

${ }^{8}$ Source: World Bank data: https://data.worldbank.org/country/chile.

${ }^{9}$ These two statements are also included in our survey.

${ }^{10} \mathrm{We}$ use all the OECD countries available in the survey.
} 


\subsection{Chilean University System}

In Chile, students apply to colleges and majors simultaneously. This is relevant to our analysis, as it will allow us to isolate the effect of self-selection into economics from exposure to an economics major. In what follows we discuss the admission system in detail.

The Chilean admission system is a centralized system where 36 universities, including the most prestigious ones, participate. This system is administered by the "Department of Evaluation, Measurement and Educational Registration" (DEMRE), which is part of the University of Chile.

Before graduating from high school, students must register for a national college admission test (the Prueba de Selección Universitaria, PSU), which is comparable to the Scholastic Aptitude Test (SAT) in the United States. The PSU includes two mandatory tests in mathematics and language and two optional tests, in history and science. Students take the PSU test in December and receive their score in early January. Based on their score, students apply to majors through the centralized system. Students can rank up to 10 choices of "careers" ("carreras") in order of preference. A career is a combination of a university and a field of study. That is, in each of their 10 choices, students must specify both the degree program and the university that they would like to attend.

After students submit their applications, DEMRE allocates students to slots. Students are ranked based on a deterministic function of high school GPA and national standardized test scores (this deterministic function varies by degree program and university). Students are admitted to their most preferred major for which the student's score is greater than the cutoff score, where the cutoff score is the score of the last student admitted to the program. This corresponds to a university-preferred Gale-Shapley algorithm.

Because the cutoff score depends on the students that apply to each program, at the time of application students do not know with certainty if they will be accepted to their preferred program and university. ${ }^{11}$ However, the algorithm is strategy-proof for students, so that they have incentives to reveal their true preferences.

\footnotetext{
${ }^{11}$ Even though they do not have certainty about being accepted, students know the cutoff applied by every career in the previous year, so they can estimate the probability of being accepted.
} 


\subsection{Economics in Chile}

Undergraduate economics is taught as a hybrid major between Economics and Business, called "Ingeniería comercial" (Commercial engineering). The commercial engineering major was first offered by the Université Libre de Bruxelles in Belgium in 1903. It was first taught in Chile by the University of Chile in 1935. The Pontificia Universidad Católica (PUC) followed closely starting its program in 1942. The program was then offered by the Universidad Adolfo Ibañez in 1957, Universidad de Concepción in 1957, Universidad de Valparaíso in 1958, and Universidad de Santiago in 1980 (Lopez Bohle and Paredes Rojas, 2007). In 1981 a new law allowed the creation of new private universities, increasing the number of universities from 8 before 1980 to 60 in 1990 (Larroulet Vignau and Domper, 2006). Many of these new universities started teaching Business and Economics. ${ }^{12}$

Business and Economics is typically taught in 10 semesters. According to University of Chile's website, it is a "degree aimed at young people interested in humanistic and scientific knowledge and with a deep capacity for reflection and analysis, and motivated by micro and macro economic phenomena and in the problems associated with the allocation of resources in the economy and society, or by phenomena associated with the management and direction of companies and organizations, in their different areas, including finance, marketing and human resources management." 13 Lopez Bohle and Paredes Rojas (2007) compare coursework in B\&E for 10 universities. ${ }^{14}$ On average, B\&E students take $12 \%$ of courses in Economics (roughly 7 full-credit courses), followed by General Interest (11\%), Electives (10\%), Finance (7\%) English (6\%) and Strategy (6\%). Most economic courses follow standard textbooks. ${ }^{15}$

In 2017, 52 out of 59 Universities offered Business and Economics. Figure 2 shows that the percentage of students in B\&E in Chile has increased steadily since 2005, going from $5 \%$ to $6.7 \%$.

\footnotetext{
${ }^{12}$ In 1983, from the 17 Universities that we have information, $60 \%$ taught Business and Economics.

${ }^{13}$ http://www .uchile.cl/carreras/4966/ingenieria-comercial

${ }^{14}$ They focus on the specialization in Business within B\&E. Students following the specialization in Economics are exposed to more economics courses.

${ }^{15}$ For example, textbooks used in the course "Introduction to Economics" (first semester) at the University of Chile are Samuelson and Nordhaus (2009) and Mankiw (2011).
} 


\subsection{Women and Higher Education}

Chile has one of the the highest first-time tertiary entry rates among OECD countries: fully $89 \%$ of young adults enter tertiary education (OECD, 2018). When considering only first time tertiary entry rates below the age of 25 , the percentages are $76 \%$ for women and $66 \%$ for men, while the OECD average is $61 \%$ for women and $49 \%$ for men. In 2017 , women constituted $54 \%$ of total enrollment in Universities.

Although women have surpassed men in higher education enrollment since 2009, there are still important differences in the type of majors women follow. In particular, women constitute only $24 \%$ of total enrollment in technology majors, while they reach $72 \%$ of total enrollment in health and $70 \%$ in education. Business and Economics is a more balanced field, with $43 \%$ women, as shown in Figure 3. This figure is comparable to the share of women undergraduates in economics in the U.S., which fluctuates around 31\% (Siegfried, 2014). The share of women in economics has remained essentially constant over the sample period.

\section{The Survey}

We conducted a pilot survey in January, 2017 for B\&E and accounting students in one university ("University 1"). On the day of registration, first year students were invited to complete the survey after they finished activating their computer account. We estimate the response rate at $25 \%$ for B\&E and $28 \%$ for accounting. ${ }^{16}$ Between March and June, 2017, we conducted the first wave of the survey. First year students from 7 universities, including the university from the pilot study, were invited to complete the survey by email. ${ }^{17}$ Based on enrollment data for these universities-majors, we estimate the average response rate at 9.8\%. ${ }^{18}$ We conducted the second wave between August and October, 2017. Upperclass

\footnotetext{
${ }^{16}$ Students were not required to register on registration day, but about two-thirds typically do. Therefore to compute the response rate we include all students enrolled in B\&E and accounting in University 1, and counted as respondents those who participated in the pilot.

${ }^{17}$ Even though students from only some universities were invited to participate in the study, because the invitation was distributed by email, it could reach students in other universities. Students from B\&E and Accounting in University 1 were asked not to answer the survey in wave 1 if they had already done so during registration day.

${ }^{18}$ Some universities only agreed to distribute the survey to their student email list without sharing the actual list with us. Therefore we do not know the exact number of emails that were sent out, and we cannot calculate the exact survey response rate. For B\&E and Accounting in University 1, we counted as respondents students who participated in the pilot and in wave 1 .
} 
students from the same 7 universities were invited to complete the survey by email, and offered to enter a lottery for one pair of movie tickets for participating in the study. The average response rate for this wave was 5.7\%. ${ }^{19}$ In March 2018 we conducted a third wave where we invited first year students from the same universities to complete our survey, and again offered to enter a lottery for one pair of movie tickets for participating in the study. The average response rate for this group was 10.9\%. In October 2018 we conducted a limited follow-up study (wave 4) with the students from University 1 that were interviewed in the pilot study. We contacted the 157 students from the pilot and invited them to answer a follow-up survey. The follow-up survey included the same questions form the pilot survey plus some additional questions to help us disentangle some mechanisms. Students were contacted by email to their institutional accounts and were offered to enter a lottery for one pair of movie tickets for participating in the study. Our response rate for the follow-up survey was 22\%. Finally, in May 2019 we conducted a second follow-up study (wave 5) with the students from the 7 universities that were interviewed in March 2018. We contacted 666 students that were interviewed in March 2018 and had given contact information to answer the follow-up survey. Students were offered to enter a lottery for two iPads. Our response rate for this second follow-up was $44 \% .{ }^{20}$ Figure 4 shows the timeline of the survey, including waves 0 to 5 .

Table 1 shows the number of students by university and year of study, and the proportion of those studying B\&E. On average 26 percent of our sample studies B\&E. Even though we see important differences in the sample of students in each university, all universities have some representation of Business and Economics students. Most of our sample is concentrated in 7 universities. There are 85 students who report studying in universities that we did not directly invite to participate. ${ }^{21}$ In total, we have data on students from 16 different universities. Table 2 shows the distribution of students across fields and waves. The fields with a highest proportion of students are engineering (26\%), business and economics $(26 \%)$, accounting $(12 \%)$ and law $(11 \%)$.

Our final sample consists of 3,723 students: 1,816 first-year students from the pilot

\footnotetext{
${ }^{19}$ The response rate is computed considering students enrolled in years 2 to 6 in each program.

${ }^{20}$ If we calculate the response rate using all the students in wave 3 (instead of the students that provided contact information) the response rate is $34 \%$. The higher response rate in the last wave is probably due to the fact that students were contacted through a popular messaging app (Whatsapp), as well as by email.

${ }^{21}$ Notice that 13 of these students are in wave 5 (the follow-up to wave 3 ), so they might have changed university over the course of a year.
} 
(157), first wave (808) and third wave (851); and 1,907 upperclass students from the second wave $(1,528)$, fourth wave (34) and fifth wave (345). ${ }^{22}$

\subsection{Measuring gender bias}

Students in our sample answered questions on both explicit and implicit biases and beliefs, and some questions on their sociodemographic characteristics. We measured implicit bias using the gender-career and gender-science versions of the Implicit Association Test (IAT, Greenwald, McGhee, and Schwartz, 1998). ${ }^{23}$ To measure explicit bias, we administered a shortened version of the Ambivalent Sexism Inventory (ASI, Glick and Fiske, 1996), which distinguishes between hostile and benevolent sexism. Hostile sexism captures negative feelings towards women (e.g., "Women try to gain power by controlling men."); while benevolent sexism represents an ideology that offers protection to women who conform to traditional gender norms (e.g., "men should be willing to sacrifice their own well-being in order to provide economic stability to women.")

We also asked students a battery of questions on gender attitudes (similar to those asked in the World Values Survey), and beliefs about gender differences in mathematical ability. Finally, we asked students to assess the importance of various factors (including discrimination and differences in preferences and skills) for explaining the gender pay gap. The rationale for these questions is that individuals with more traditional gender attitudes are less likely to attribute gender differences in labor market outcomes to discrimination, and more likely to rationalize these gaps with differences in skills and preferences (human capital, risk aversion, competitiveness, preference for work-life balance).

Based on the answers to these questions, we constructed five additional measures of

\footnotetext{
${ }^{22}$ We collected data from 4,007 students. We excluded 31 students for whom we do not have information on their university or major. From wave 2 we excluded 83 students who declared to be first year students, and 170 students who declared to be in 7 th to 9 th year (students took 12.6 semesters on average to graduate in 2017 from undergraduate university degrees in Chile).

${ }^{23}$ There is an intense debate over whether implicit biases are predictive of discriminatory behavior (see McConnell and Leibold, 2001; Blanton, Jaccard, Klick, Mellers, Mitchell, and Tetlock, 2009; McConnell and Leibold, 2009; Forscher, Lai, Axt, Ebersole, Herman, Devine, and Nosek, 2019, among others). Even though most of this research has addressed race stereotypes, the criticism should also apply to gender stereotypes. In the economics literature, there have been a number of studies that have found a link between implicit biases and behavor: Rooth (2010) finds that Arab-Muslim job applicants in Sweden are less likely to be called back by employers with a stronger implicit bias against them; Glover, Pallais, and Pariente (2017) find that minority grocery cashiers in France perform less well on the job on days in which they are paired with managers with stronger implicit bias; finally, Carlana (2019) shows that teachers' IAT scores correlate with students' gender gap in math performance, supporting a link between attitudes and behavior.
} 
gender bias. Based on the pilot, we used a cluster latent variable analysis (Vigneau and Qannari, 2003) to group the remaining variables into the following categories: i) traditional gender roles, measuring the extent to which respondents agree with statements that women working outside of the home have a negative effect on family life; ii) proactive (or normative) gender roles, measuring the extent to which respondents agree that society should change to promote gender equality; iii) beliefs about gender differences in mathematical ability; iv) beliefs that the gender pay gap is due to discrimination; and v) beliefs that the gender pay gap is due to differences in skills and preferences. The full set of survey questions, and their grouping into our different measures of gender bias, is reported in the Appendix.

Finally, we took the principal component of nine measures to calculate an aggregate gender bias score. ${ }^{24}$ Table 3 shows the correlation matrix for all measures. The correlation between the different measures is positive and significant in almost all cases. The only pair of variables that have a negative correlation is the belief that the gender gap is due to discrimination and the belief that the gender gap is due to skills and preferences. The correlation between the Gender and Science IAT and the other measures is always positive but small and not significant for benevolent sexism, traditional gender roles, the belief that the gender gap is due to discrimination and the belief that the gender gap is due to skills and preferences. However, we do find a significant correlation between the Gender and Science IAT and beliefs about gender differences in mathematical ability, which is expected since both variables are measuring similar aspects of gender biases.

Table A-2 in the appendix shows the summary statistics of our nine measures of gender bias, and the aggregate bias score. ${ }^{25}$ In most of the measures sexism decreases when comparing first year and upperclass students. Sexism also decreased between first year students in 2017 and 2018. ${ }^{26}$ However, both first year cohorts are in general more sexist than upperclass students.

As a first validity check, we look at whether there are gender differences in our measures. If the measures do indeed capture gender bias, we expect women to exhibit lower scores than men. ${ }^{27}$ Table 4 shows that on six of the nine core measures this is indeed the case.

\footnotetext{
${ }^{24}$ We calculated the weights of the principal component using the answers of students the pilot survey, and waves 1 to 3 .

${ }^{25}$ All the measures are standardized to have mean zero and standard deviation 1 in the entire sample.

${ }^{26}$ The third wave took place after the onset of the \#MeeToo movement, in October 2017, as shown in Figure 4.

${ }^{27}$ All the measures have been standardized to have mean zero and standard deviation 1 in the whole population, and are rotated so that higher scores indicate higher gender bias.
} 
The gap ranges between 0 and about $0.6 \sigma$, depending on the measure. The gender gap in the summary gender-bias measure is about two thirds of a standard deviation. We find larger differences in the hostile sexism measure than in the benevolent sexism measure, as found in Glick and Fiske (1996). Men have significantly more traditional attitudes about gender roles, and are more likely to believe that women have lower mathematical ability. Men are also significantly less likely to believe that labor market discrimination plays an important role in explaining the gender pay gap. The only two measures where we do not observe a significant gender gap are the IAT scores and the "skill and preferences" measure. ${ }^{28}$ Regarding the former, it is perhaps not surprising that implicit biases are more difficult to detect. The gender gap in the IAT scores is also smaller than that observed for the other measures. The latter result is somewhat more surprising, especially in light of the fact that the skill and preferences measure is positively correlated with all the other measures, except for the discrimination measure (Table 3).

Finally, we collected personal information including gender, age, high school type, and socioeconomic background. Table A-3 shows descriptive statistics for these control variables. On average, students from all waves are comparable in most characteristics. Upperclass students tend to come more from single-sex schools rather than coeducational schools, than first year students. Also, upperclass students have higher GPA and PSU scores, possibly reflecting that these characteristics predict higher retention rate.

Because we have a wide range of outcomes, we must address the concern of false positives due to multiple hypothesis testing. We adopt three measures in this regard. First, we have kept the same questions throughout the study. Second, we have created an index constructed as the principal component of the nine measures, to reduce the number of hypotheses tested. Finally, in the appendix we reproduce the main tables with p-values corrected for multiple hypotheses testing, following Romano and Wolf (2005a,b). ${ }^{29}$

\subsection{The \#MeToo Movement and Social Desirability Bias}

We begain collecting our data in January 2017 (see Figure 4). Since then, a number of events occurred, both in Chile and worldwide, which could have influenced the way in which students answered our survey questions.

\footnotetext{
${ }^{28}$ When we do not include controls, there is a significant difference in the IAT-science score. Even with controls, the difference is large $(0.2 \sigma)$, although not significant.

${ }^{29}$ We use the implementation in Stata of Clarke, Romano, and Wolf (2019).
} 
In October 2017, following the revelations of extensive sexual abuse by Hollywood producer Harvey Weinstein, the \#MeToo hashtag spread virally on social media, leading to a wave of allegations of widespread and pervasive sexual abuse and harassment in all sectors of society. The movement spread globally, and quickly reached Chile as well. Indeed, in April 2018, the faculty of Philosophy and Humanities of the Universidad Austral was occupied, in reaction to a case against a professor found guilty of sexual harassment. Several university faculties and high schools were also occupied or went on strike during the first semester (March-August), raising awareness of the prevalence of sexism in academia. Also, as a response to the feminist movement, Chilean president Sebastián Piñera announced a series of measures to reach equality between men and women, known as the "Women's Agenda."

The issue of sexism within the economics profession came forcefully to the fore at roughly the same time. In August 2017, Alice Wu's article on widespread mysoginy in an anonymous online forum frequented by many economists was quoted in a New York Times article, and exposed the toxic environment faced by many women within the profession.

These developments may have led respondents to be more cautious in expressing openly sexist views on a survey. The global resonance of the \#MeToo movement may have also led some individuals to genuinely adopt less gender-biased views. It is intructive to examine whether there are any notable trends in our measures of gender bias over time.

As shown in Figure 4, students interviewed in the pilot and in Waves 1-2 completed the survey almost entirely before the emergence of the \#MeToo movement. By contrast, Wave 3 took place after \#MeToo had already become a global phenomenon, and Waves 4 and 5 were conducted after the feminist occupations and strikes in Chilean Universities.

Figure 5 shows the evolution of the aggregate score over time, after netting out university and field of study fixed effects. Two main patterns emerge from the figure: first, gender bias is substantially lower for upperclass relative to first-year students; second, there is a clear downward trend in the aggregate score. The average score decreased by $0.20 \sigma$ from March 2017 to March 2018 for first-year students, and by $0.26 \sigma$ between August 2017 and May 2019 for upperclass students.

The decrease in measured gender bias could be due to either a genuine change in attitudes following the revelation of the \#MeToo movement, or to social desirability bias, whereby students refrain from expressing openly sexist opinions in surveys. To shed light 
on this matter, Figures 6 and 7 look separately at the evolution of the hostile sexism measure and the gender and science IAT score. Hostile sexism exhibits a particularly pronounced downward trend, with a decrease of $0.21 \sigma$ and $0.37 \sigma$ for first year and upperclass students, respectively. On the other hand, there is basically no downward trend in the IAT score, which, by definition, is more difficult to consciously manipulate. ${ }^{30}$ This suggests that the decrease in gender bias over time has more to do with social desirability bias than to a genuine change attitudes. It is important to keep this in mind as we analyze the data.

\section{Results}

\subsection{Are economists more sexist?}

We start by documenting whether economics students are more gender biased relative to students in other fields, regardless of year of study. Table 5 compares students in Business and Economics to students in other disciplines. ${ }^{31}$ The first two columns report the mean value of each one of our measures of bias (rows 1-9) and of the aggregate gender bias score (row 10) for B\&E and non-B\&E students. Column 3 reports the raw difference in means and its standard error, adjusted for clustering at the university/major level. Column 4 reports the regression-adjusted difference in means, after controlling for student gender, mother's education, a dummy for whether the mother worked when the student was growing up, high school sector (public, private or voucher), high school type (mixed, single-sex school and single-sex classroom), and university dummies.

For eight of the nine individual measures, we find that B\&E students are non-negligibly more gender biased than non-B\&E students. Five of the differences are statistically significant at the $5 \%$ level (in the specification with controls). The bias of B\&E students appears to be particularly pronounced in the IAT-career score, hostile and benevolent sexism, the skills and preferences measure and the gender roles-normative measure. ${ }^{32}$ The raw gap in the aggregate gender-bias score is 0.2 standard deviations, and it falls to 0.14 standard

\footnotetext{
${ }^{30}$ There is also no difference in the IAT score between first year and upperclass students, again suggesting that some of the differences observed for the other measures may be due to the fact that older students are more cautious about openly expressing sexist views. This evidence is consistent with Cao and Banaji (2016), who suggest that implicit gender biases are relatively immune to counterstereotypic facts.

${ }^{31}$ Table A-6 in the appendix reports p-values adjusted for multiple hypotheses testing.

${ }^{32}$ Broadly speaking, this measure captures the extent to which respondents agree with statements that society should change or intervene to promote more gender equality (e.g., "Men should assume a greater degree of responsibility in domestic work than they currently do.")
} 
deviations after inclusion of controls. In other words, the gap between B\&E and non-B\&E students is about one quarter as large as the gap between men and women. This is a sizeable difference.

Columns 5 and 6 replicate the specification of Column 4 separately for men and women. Across most measures, the B\&E-non B\&E gap is quite similar for men and women, with a couple of exceptions (female B\&E students exhibit more bias on the IAT-Science score, male B\&E students exhibit more bias on the IAT career score and the belief in differences in mathematical ability.)

\subsection{Selection or training? Identification}

The difference in biases between students in B\&E and students in other fields may reflect either pre-existing differences between individuals who choose to major in economics and those who choose to major in other fields; or, it may be a result of training in economics (or a combination of the two). To test if the difference between economists and non-economic students is due to selection or training, we use a difference-in-difference approach. We run the following equation,

$$
\begin{gathered}
y_{i m c}=\alpha+\beta B \& E_{i m c}+\gamma \text { Upperclassmen }_{i m c}+ \\
\delta B \& E \times \text { Upperclassmen }_{i m c}+\theta^{\prime} X_{i m c}+\varepsilon_{i m c}
\end{gathered}
$$

where Upperclassmen is a dummy variable that indicates students in their second to sixth year. If economic training causes biases, then biases should increase with exposure to training in economics. Specifically, the bias of upperclassmen B\&E students should be larger than the bias of B\&E students in their first year; therefore, we should expect a positive and significant $\delta$. If the difference is due to selection, we expect a large difference in the first year that does not increase for upperclass students. If this is the case, we should expect a positive and significant $\beta$ and $\delta=0$. Finally, $\gamma$ captures the change in gender bias between the first and subsequent year for non-B\&E students. As before, $X_{i m c}$ are controls for student gender, mother's education, high school sector (public, private or voucher), high school type (mixed, single-sex school and single-sex classroom), and university dummies.

The interpretation of $\delta$ as the causal effect of economics training hinges on two key identifying assumptions. First, there can be no differential selection of students into B\&E across cohorts. This assumption would be violated if the set of students who chose to study 
economics became less (or more) gender-biased over time. Alternatively, the assumption could be violated in our sample because of differential non-response across majors and cohorts. For example, if upperclassmen biased B\&E students were more likely to respond to the survey than less biased ones, we would obtain a spurious difference-in-difference estimate.

While it is difficult to completely rule out these possibilities, we provide some evidence against differential selection. In Table 6 we assess whether there are any differences between $\mathrm{B} \& \mathrm{E}$ and non-B\&E students in background characteristics, and whether they differ across cohorts. In practice, we estimate a series of difference-in-difference regressions analogous to equation (1), but where we use each of the background characteristics as the dependent variable. We find essentially no differences between B\&E and non-B\&E students in both cohorts (the only exceptions are for public and private schools), and all the differencesin-differences coefficients are very close to zero. In sum, at least in terms of observable characteristics, there is very little evidence of differential selection. ${ }^{33}$

The second key assumption is the traditional parallel trends assumption of any differencein-differences analysis. In our context, this means that students who choose to major in economics must not be differentially more likely to become more gender-biased over time, regardless of which training they actually acquire. One possible way to address this concern is to exploit the institutional features of the Chilean university admission system and implement an instrumental variable strategy, where actual enrollment in a B\&E degree is instrumented by predicted enrollment based on PSU score and high school GPA and each student's stated ranking of "careers." The results of this analysis are discussed in Section 4.5 .

\subsection{Selection or training? Results}

Table 7 a shows the main results of our differences-in-differences model. ${ }^{34}$ The first three columns show, respectively, the gap between B\&E and non-B\&E freshmen, between B\&E and non-B\&E upperclassmen, and the raw difference-in-differences coefficient for all stu-

\footnotetext{
${ }^{33}$ In Table A-3 we find some significant differences between freshmen and upperclassmen in background characteristics. Upperclassmen are more likely to come from a single-sex school (single-sex schools outperform coeducational schools in our sample by $0.33 \sigma$ ) and to have higher PSU scores and high school GPAs, probably reflecting differential attrition of lower ability students. However, the results in Table 6 suggest that this differential attrition is similar across fields.

${ }^{34}$ Table A-7 in the appendix reports p-values adjusted for multiple hypotheses testing.
} 
dents in our sample. These regressions include controls for all of the background characteristics, and, in column 3, the interaction of background characteristics with the upperclass dummy. ${ }^{35}$

Among freshmen students, B\&E students have significantly higher scores in five of the individual measures (Hostile, Benevolent, Gender roles-normative, Math, and Skills and preferences), as well as in the aggregate score. Therefore, there appears to be some evidence in support of the selection hypothesis. On the other hand, the gaps between B\&E and nonB\&E upperclass students are much more pronounced. In addition to the five measures above-mentioned, the IAT gender-career also displays large differences between B\&E and non-B\&E upperclass students. ${ }^{36}$ The difference-in-differences estimator is positive for all measures (with the exception of the skills and preferences measure), but never statistically significant at conventional levels. For the sample as a whole, the evidence in support of the training hypothesis is somewhat mixed.

These results, however, mask important differences by gender. Columns 4-6 and 7-9 of Table $7 \mathrm{~b}$ show the results of estimating equation (1) separately for men and women. For women, there is some evidence of selection: economics students are more gender-biased upon entry, and the gap increases at most moderately in subsequent years. For male students, on the other hand, we observe a moderate-sized but insignificant gap in the aggregate score at entry, a large and statistically significant gap among upperclassmen, and a large and statistically significant difference-in-differences estimate. This result seems to be driven by the effect of studying economics on benevolent sexism and the belief that the gender pay gap is due to discrimination, although only the benevolent sexism measure remains statistically significant after adjusting for multiple hypotheses testing (A-7). The combined evidence from this section suggests that B\&E students are more gender-biased in part because of differences that were already present upon entry; but, especially for men, exposure to economics increases the degree of bias.

Our results could be due not to any particular feature of B\&E training, but rather to some other major that causes students to become less gender biased. Therefore, we reestimate equation 1 excluding one major at a time from the list shown in Table 2. Figure A-1

\footnotetext{
${ }^{35}$ To maximize sample size, we retain all observations with valid data, including students in the follow-up survey in Waves 4 and 5, but treat these as if they were independent observations. Results are essentially unchanged if we discard these observations.

${ }^{36}$ The difference in the math measure is larger than for first year students but it is no longer statistically significant.
} 
shows the results of studying $B \& E$ on the aggregate score for first year students, upperclass students, and the difference-in-difference estimate. Results for male and female students are shown in Figures A-2 and A-3 respectively. The results for male students show that the treatment effect of studying B\&E is not driven by a particular major: the difference-indifference coefficient is always positive and statistically significant, ranging from 0.126 to 0.253 standard deviations. For female students, the effect is never statistically significant.

\subsection{Robustness check: Within Subject analysis}

The interpretation of the difference in difference coefficient as a causal effect in the betweensubject analysis rests in the assumption that there are no differences in selection into B\&E across cohorts. While the results in Table 6 show that we can rule out differential selection in terms of observable characteristics, it is still possible that there are differences in selection into $\mathrm{B} \& \mathrm{E}$ in non-observable characteristics.

To address these concerns, we conducted a follow-up study for a subset of our sample. We use this longitudinal data to perform a within-subject analysis. As explained before, in October 2018 and May 2019 we contacted 823 students who were interviewed in the pilot survey and in March 2018 respectively, and invited them to answer a follow-up survey. Our response rate for the follow-up survey was 39\%. This results in a panel data set for 321 students. ${ }^{37}$ Of these 321 students, $23 \%$ study economics, $26 \%$ study engineering, $16 \%$ study accounting and $14 \%$ study law.

We thus modify model (1) to include a student fixed effect $\eta_{i}$,

$$
\begin{aligned}
y_{i m c}= & \alpha+\beta B \& E_{i m c}+\gamma \text { Upperclassmen }_{i m c}+ \\
& \delta B \& E \times \text { Upperclassmen }_{i m c}+\eta_{i}+\varepsilon_{i m c}
\end{aligned}
$$

where BEEE and Upperclassmen are defined as before. This model is estimated in first differences.

The response rate was lower for economic students (30\%) compared to non-economics students (43\%). The response rates was also lower for men compared to women: $35 \%$ versus $44 \%$. Given the high attrition rate across waves, it is important to check that attrition is not related to underlying gender attitudes, and that it does not differ between B\&E and non-

\footnotetext{
${ }^{37}$ The total number of students who answered our follow-up survey was 376 . There were 55 individuals who either answered only the follow-up survey or who we were unable to match.
} 
B\&E students. Using the full sample of students for which we have the average score in the pilot study and the third wave, we estimate a linear probability model for the probability of follow-up, regressed on the aggregate gender-bias score in the first wave, a dummy for $\mathrm{B} \& \mathrm{E}$, and the interaction between the two.

The results are presented in Table A-4. B\&E students are less likely to answer the followup, and there is a mild and significant negative association between the gender-bias score and the probability of follow-up. However, and more importantly, there is no significant effect of the interaction between the gender-bias score and the difference between economics and non-economics students.

Even though we do not observe selective attrition in our sample, there could still be unobservable characteristics affecting the response rate of students in our sample differentially, depending on whether they study B\&E. To alleviate this concern, we use a Heckman selection model (Heckman, 1979) to correct for attrition bias in the model with student fixed effects. The selection equation includes a dummy for whether the student is enrolled in Business \& Economics (B\&E), the score in either wave 0 or 3, and a dummy for whether the student gave his/her contact phone number. ${ }^{38}$

We proceed to estimate the effect of Business and Economics for students in our panel. Results are shown in Table 8a. ${ }^{39}$ As before, the first three columns show, respectively, the gap between $\mathrm{B} \& \mathrm{E}$ and non $\mathrm{B} \& \mathrm{E}$ freshmen, between $\mathrm{B} \& \mathrm{E}$ and non $\mathrm{B} \& \mathrm{E}$ upperclassmen, and the difference-in-difference coefficient without including student fixed effects. The first two columns include controls for all the background characteristics, and in column 3, the interaction of the background characteristics with the upperclass dummy. This column is equivalent to column 3 of Table 7a, for the limited sample of students that we can follow longitudinally. Column 4 shows the difference-in-difference coefficient of the model with student fixed effects (and no controls). Finally, Column 5 shows the difference-in-difference coefficient of the model with student fixed effects and a Heckman correction for attrition.

The gap between $\mathrm{B} \& \mathrm{E}$ and non-B\&E freshmen, and between $\mathrm{B} \& \mathrm{E}$ and non $\mathrm{B} \& \mathrm{E}$ upperclassmen is smaller in the longitudinal sample than in the whole sample. In Table 7a both first year and upperclassmen B\&E students had a statistically significant coefficient on the aggregate score, of 0.11 and 0.20 s.d. respectively. In the longitudinal sample, the difference

\footnotetext{
${ }^{38}$ Students were asked to give their contact email to participate in the follow-up. In addition, in wave 3 we asked them to give their phone number, which $75 \%$ of them did.

${ }^{39}$ Table A-8 in the appendix reports p-values adjusted for multiple hypotheses testing.
} 
between $\mathrm{B} \& \mathrm{E}$ and non $\mathrm{B} \& \mathrm{E}$ freshmen, and between $\mathrm{B} \& \mathrm{E}$ and non $\mathrm{B} \& \mathrm{E}$ upperclassmen is no longer significant. However, the difference-in-difference coefficient in the model with student fixed effects is similar: $0.092 \sigma$ versus $0.112 \sigma$. When controlling for selection (column $5)$, the results show a positive and statistically significant difference-in-difference effect on the aggregate gender-bias score, which is driven mostly by the math, discrimination and skills and preferences measures. ${ }^{40}$ Compared to the previous results, the effect is similar in magnitude to the difference between B\&E and non B\&E students - regardless of their year of study-, reported in Table $5(0.1792 \sigma$ versus $0.1442 \sigma)$.

To explore whether there are differences by gender, columns 6-7 and 8-9 of Table 8b show the results of estimating our models separately for men ad women. Overall, our results are broadly consistent in sign and magnitude with the between-subject analysis, but less precise. For male students, while in the between-subject analysis we found a difference-in-difference coefficient of 0.183 s.d., the coefficient for male students in the within-subject analysis, after controlling for selection, is 0.197 s.d. For female students, although the difference-indifference coefficient for the principal component is not significant in any specification, the coefficient in the longitudinal sample is similar in magnitude to the effect found for men. ${ }^{41}$

It is interesting to note that two of the measures where we find the largest effect in this sample are the ones in which respondents are asked to evaluate the relative importance of various explanations for the gender wage gap ("discrimination" and "skills and preferences"). These measures are perhaps the ones for which the definition of "gender-bias" is most controversial. One possible interpretation of this result is that economics students internalize the view that a gender gap in wages is not necessarily only due to labor market discrimination. We caution against pushing too hard on this interpretation: First, we obtain this result only in the longitudinal sample, but not in the larger full sample. Second, not all the results remain statistically significant after adjusting for multiple hypothesis testing (Table A-8 in the appendix).

\subsection{More robustness checks: IV analysis}

As discussed before, a key assumption for any difference-in-difference analysis is the parallel

\footnotetext{
${ }^{40}$ We also calculated Lee bounds (Lee, 2009). Our bounds contain zero so the positive treatment effect is not robust to this procedure, which is expected given the high levels of attrition.

${ }^{41}$ In columns 5, 7 and 9 we have restricted the sample to include students who gave contact information (email or phone number). Results are similar in magnitude and significance if we also include students who were not contacted for the follow-up.
} 
trends assumption. In our setting, it is possible that students who chose to study economics had a higher propensity to be "indoctrinated" and become more gender-biased over time, regardless of which training they actually acquire. The within-subject analysis is not sufficient to reject this possibility. Instead, we address this concern using an instrumental variable strategy that exploits the features of the centralized admission system in Chile to generate quasi-experimental variation in enrollment into economics (Pop-Eleches and Urquiola, 2013; Lucas and Mbiti, 2014; Kirkeboen, Leuven, and Mogstad, 2016; Zimmerman, 2019).

Specifically, we use information on the PSU score, the high school GPA and the student's ranking of major-college combinations to construct an instrument for B\&E enrollment. First, we restrict the sample to include only students who listed at least one B\&E major in their ranking of careers. For each of these students, we construct the variable "Above cutoff score" as a dummy variable that takes the value of 1 if the student's admission score is greater than the cutoff score of the lowest ranked B\&E department within her choice set. We then use this variable as an instrument for actual B\&E enrollment in a 2SLS regression, separately for first-year and upperclass students. ${ }^{42}$ It is easy to see that this instrument satisfies the relevance condition: to be enrolled in a B\&E program, one needs (in general) to have a score higher than the cutoff. However, the instrument does not predict B\&E enrollment perfectly: it is possible for a student to have a score below the cutoff and still be admitted to a B\&E program (this is a relatively small group that may include student-athletes or students who are given preferential treatment by universities because they come from disadvantaged schools or backgrounds); or, more commonly, a student may have ranked a different major above B\&E and had a sufficiently high score to be admitted to both. The key identifying assumption is that, conditional on applying to an economics program, whether one's score is above or below the cutoff of the lowest ranked program she applied to is uncorrelated with any unobserved propensity to become more gender-biased. For this reason, all regressions also include the cutoff score of the lowest ranked $\mathrm{B} \& \mathrm{E}$ program one applied to as a control variable.

The results of the IV regression are presented in Table 9. We focus first on the results for the whole sample (Panel A). Despite a relatively strong first stage, the 2SLS estimates are

\footnotetext{
${ }^{42}$ The logic of this instrument is similar to that of a Regression Discontinuity (RD) design that compares students just above and just below the admission threshold. Given the size of our sample, we do not have enough power to implement a traditional RD design. The 2SLS strategy can be thought of as a special case of the RD design where we fit a polynomial of degree zero to the running variable on both sides of the threshold, and we allow an infinite bandwidth.
} 
highly imprecise. The point estimates, taken at face value, indicate a large negative relationship between B\&E and gender bias among first year students, which becomes substantially weaker among upperclass students. The point estimate for the difference-in-difference coefficients is about two thirds of a standard deviation, substantially larger than the corresponding estimate in Table 7a. The patterns in the male and female samples (Panels B and $\mathrm{C}$ of the table) are broadly similar, pointing to a fairly large difference-in-difference point estimate, with a large associated standard error. On the whole, the IV results are mostly inconclusive, but they do not provide much support to the notion that students who choose $\mathrm{B} \& \mathrm{E}$ are unobservably more likely to become more gender biased (if anything, the contrary might be true). However, we should exercise caution in drawing these conclusions given the imprecision of the estimates.

\section{Possible Mechanisms}

In this section, we analyze possible mediating mechanisms that can give rise to the gap between $B \& E$ and non-B\&E students. We examine in turn the role of political ideology and religiosity, the exposure to female peers and the exposure to female faculty.

\subsection{Political ideology and religiosity}

As discussed above, previous research has shown that studying economics lowers support for government intervention in markets, i.e., it moves individuals to the right on the political spectrum (Hammock, Routon, and Walker, 2016). If support for the right on economic issues is also accompanied by a more conservative stance on social and gender issues, one would observe a positive difference-in-differences estimate, which is not directly attributable to the content matter of economics.

We measured political ideology in the survey by asking students to indicate where they would locate themselves in the political spectrum on a 0 to 10 scale, where 0 corresponds to the left, and 10 corresponds to the right. B\&E students, with and average score of 5.2, are indeed more right-wing than students from other disciplines (average score 4.1).

Columns 1-3 in Table 10 reproduce the main results from Tables $7 \mathrm{a}$ and $7 \mathrm{~b}$ when using the aggregate score as the dependent variable. The table reports the coefficient on the B\&E dummy, representing the difference in score among first year students, the coefficient on the upperclass dummy, and the difference-in-differences coefficient. Columns 4-6 show the 
effect of studying B\&E controlling for political ideology. As expected, right wing ideology is positively correlated with higher levels of gender bias. A one standard deviation move to the right on the political ideology scale (i.e., a move of 2.2 points in the left-right scale) is associated with a $0.4 \sigma$ increase in the gender bias score, about two - thirds the size of the difference between men and women. Controlling for political ideology substantially reduces the coefficient on the aggregate gender bias score for both entering students and upperclassmen. In fact, after controlling for political ideology, B\&E students are less genderbiased at entry, and are only slightly more gender-biased in later years, although these differences are not statistically significant. However, the difference-in-differences estimate is essentially unaffected for the whole sample. For male students, the difference-in-differences estimate is still positive and significant, although slightly smaller (political ideology can explain $30 \%$ of the effect for men). We therefore conclude that, while political ideology can explain almost the entirety of the gender bias gap between B\&E and non-B\&E students in levels, it does not explain the increase in gender bias of B\&E students after exposure to economics.

Hammock, Routon, and Walker (2016) also shows that students who are more religious are more likely to choose economics as a field. We therefore ask whether religiosity affects the gender bias gap between $B \& E$ and non B\&E students. We measure religiosity in the survey by asking students to indicate how religious they are on a scale from 1 to 4 , where 1 indicates not religious and 4 indicates strongly religious. B\&E students in our sample are more religious than other students, with an average score of 1.8 versus 1.6.

Columns 7-9 in Table 10 show the effect of studying B\&E controlling for religiosity. As with political ideology, religiosity also correlates with higher levels of gender biases. A one standard deviation increase in religiosity (i.e., a move of 0.87 points in the scale) is associated with a $0.22 \sigma$ increase in the gender bias score, about one - third the size of the difference between men and women. After controlling for religiosity, the gap in bias between B\&E and non-B\&E students at the point of entry is no longer significant. However, the extent of attenuation is not as large as the one induced by the inclusion of political ideology. There is still a positive and significant gap in later years for male students, even after controlling for religiosity. Regarding the difference-in-difference estimate, it is unaffected for both male and female students. Therefore, as was the case for political ideology, religiosity can not explain away the effect of exposure to economics on gender bias. 


\subsection{Exposure to female peers}

Peers can have a significant impact in students' decisions and beliefs (Dasgupta, Scircle, and Hunsinger, 2015; Finseraas, Johnsen, Kotsadam, and Torsvik, 2016; Dennehy and Dasgupta, 2017; Crumb, Moore, and Buontempo, 2017; Booth, Cardona-Sosa, and Nolen, 2018; Bostwick and Weinberg, 2018). We analyze whether exposure to a higher share of female peers reduces the effect of studying economics on gender biases. To this end, we collected information on the number of female students for all university/major/cohort cells in our sample, and interact the share of female students with the B\&E dummy, Upperclass, and the Difference-in-Differences dummy. ${ }^{43}$

The results of this exercise are presented in Table 11. Column 1 shows the results for all students, while columns 2 and 3 shows results for male and female students, respectively. When including the interaction with the share of female students, we find that having a larger share of female peers decreases gender bias: moving from the average share of female students in economics (42\%) to gender parity reduces the effect of exposure to economics by 0.12 s.d. The effect is particularly strong among female students, while for male students the interaction with the share of female students is negative but smaller in magnitude and not statistically significant.

\subsection{Exposure to female faculty}

As in the United States and elsewhere, economics is a field with a relatively low representation of female faculty (Boring and Zignago, 2018). This is also true in our sample. B\&E is the discipline with the lowest percentage of female faculty (14.4\%), followed by engineering (15.1\%). All other disciplines have at least $20 \%$ of female faculty. Psychology is an outlier with $51.7 \%$ female faculty. Therefore, the lack of female representation, and not economic training itself, could increase students' gender biases relative to other fields with a higher percentage of female faculty.

In the follow up survey, we directly asked students about their exposure to female instructors. We gave students 4 categories to choose from: fewer than $10 \%$ of female instructors, between 10 and 30\%, between 30 and 50\%, and more than 50\%. We then collapsed the last two categories into one (more than $30 \%$ of female instructors). Table

\footnotetext{
${ }^{43}$ The average cohort size for students in first year in our sample is 332.7 students, with a standard deviation of 225.3, a minimum of 49 students and a maximum of 1,152 students.
} 
12 shows the results of estimating our model where the difference-in-difference coefficient is interacted with the three categories of exposure to female professors. Our results show that, for the whole sample, and particularly for women, the effect of exposure to economics is larger for students who had not been exposed to female instructors. ${ }^{44}$

There are at least three possible explanations that could give rise to this result. First, if female professors are less sexist, results could be driven by students being exposed to less gender-biased instructors. Even though there is no evidence for the Chilean context, Carlana (2019) finds, using the same IAT gender-science that we use, that male math teachers in middle schools in Italy are more gender biased than female teachers. ${ }^{45}$ Second, previous research has found that female professors can have a significant effect as role models (Bettinger and Long, 2005; Dee, 2007; Carrell, Page, and West, 2010; Paredes, 2014). Finally, we cannot rule out that female professors teach economics differently (Allgood and Walstad, 2013).

\section{Conclusions}

In this paper, we have provided direct evidence on the importance of explicit and implicit biases against women among students in economics relative to other fields. We find that, on a variety of dimensions, Business and Economics students are substantially more genderbiased than students in other fields. B\&E are somewhat more biased already upon entry, before exposure to any economics training. The gap becomes substantially more pronounced among upperclassmen, in particular for male students. We also find that, for a sample of students that we can follow longitudinally, the bias increases over time. Therefore, our results suggest that economic training may increase students' biases.

We motivated this paper by the observation of unequal treatment in academic economics along seveal different dimensions. Our results are at least suggestive that part of this unequal treatment may be the result of deep biases that run through the discipline, even among students at the earliest stages of their training.

Teaching is maybe the area in which academic economists can have the largest policy

\footnotetext{
${ }^{44} \mathrm{It}$ is possible that there is also a reverse causality, where students that are more gender biased choose to have fewer classes with female instructors. However, due to availability of instructors or capacity constrains, students do not always have the possibility to choose instructors.

${ }^{45}$ Comparing blind and non-blind scores of students, Lavy (2008) does not find differences between male and female teachers in secondary schools in Israel.
} 
impact, as they can shape the way of thinking of future leaders in the business and policy world. Our results suggest that economics instructors should be particularly careful of hidden (and not so hidden) biases embedded in the material when teaching. ${ }^{46}$ Most researchers are well aware that the "real world" is often a lot more nuanced than what is presented in the simple models discussed in undergraduate classes, and principles classes in particular. It is important to share this nuance with the students.

The results also reveal that part of the difference in gender bias between $\mathrm{B} \& \mathrm{E}$ and non-B\&E students is present already upon entry, before exposure to any economics classes. Rather than absolving the discipline, this result suggests that economics could do more to appeal to a broader and more inclusive set of prospective students. Outreach initiatives that illustrate "what economists really do" may be a step in the right direction.

Finally, we find evidence that part of the gap between B\&E and non-B\&E students may be explained by differential exposure to female peers and professors. Previous literature has found that economic departments with a greater share of women faculty also have more female students (Boustan and Langan, 2019). Moreover, Langan (2019) finds that female department chairs in economic departments reduce gender gaps in tenure and publications of assistant professors, as well as reducing the gender pay gap. Our results may provide additional justification for striving to increase the number of women in the discipline.

\footnotetext{
${ }^{46}$ Stevenson and Zlotnik (2018) find that women are underrepresented in principles of economics textbooks, either as business leaders, policymakers or economists, and even in fictionalized accounts.
} 


\section{References}

Allgood, S., and W. B. Walstad (2013): "How Economists Allocate Time to Teaching and Research," The American Economic Review, 103(3), 654-58.

Ash, E., D. L. Chen, And S. Naidu (2019): "Ideas Have Consequences: The Impact of Law and Economics on American Justice," Discussion paper, ETH Zurich.

BAyer, A., And C. E. Rouse (2016): "Diversity in the economics profession: A new attack on an old problem," Journal of Economic Perspectives, 30(4), 221-42.

Becker, G. S. (1968): "Discrimination, Economic," in International Encyclopaedia of the Social Sciences, ed. by D. L. Sills, vol. 4, pp. 208-210. McMillan and Free Press, New York.

(1971): The Economics of Discrimination. University of Chicago Press, Chicago.

(1991 [1981]): A Treatise on the Family. Harvard University Press.

Bettinger, E. P., And B. T. Long (2005): "Do Faculty Serve as Role Models? The Impact of Instructor Gender on Female Students," The American Economic Review, 95(2), 152-157.

Blanton, H., J. Jaccard, J. Klick, B. Mellers, G. Mitchell, and P. E. TetLOCK (2009): "Strong claims and weak evidence: Reassessing the predictive validity of the IAT.," Journal of Applied Psychology, 94(3), 567-582.

Booth, A. L., L. Cardona-Sosa, and P. Nolen (2018): "Do single-sex classes affect academic achievement? An experiment in a coeducational university," Journal of Public Economics, 168, 109-126.

Boring, A. (2017): "Gender biases in student evaluations of teachers," Journal of Public Economics, 145, 27-41.

Boring, A., And S. Zignago (2018): "Economics: where are the women?," https:// blocnotesdeleco.banque-france.fr/en/blog-entry/economics-where-are-women.

Bostwick, V. K., And B. A. Weinberg (2018): "Nevertheless She Persisted? Gender Peer Effects in Doctoral STEM Programs," NBER Working Paper 25028.

Boustan, L. P., And A. Langan (2019): "Variation in Women's Success across PhD Programs in Economics," The Journal of Economic Perspectives, 33(1), 23-42.

CAO, J., And M. R. BAnAJi (2016): "The base rate principle and the fairness principle in social judgment," Proceedings of the National Academy of Sciences, 113(27), 7475-7480.

Card, D., S. DellaVigna, P. Funk, and N. Iriberri (2020): "Are Referees and Editors in Economics Gender Neutral?," The Quarterly Journal of Economics, 135(1), 269-327. 
Carlana, M. (2019): "Implicit Stereotypes: Evidence from Teachers' Gender Bias," The Quarterly Journal of Economics, 134(3), 1163-1224.

Carrell, S., M. E. Page, and J. E. West (2010): "Sex and Science: How Professor Gender Perpetuates the Gender Gap," The Quarterly Journal of Economics, 125(3), 1101-1144.

Carter, J. R., And M. D. Irons (1991): "Are economists different, and if so, why?," Journal of Economic Perspectives, 5(2), 171-177.

Ceci, S., D. Ginther, S. Kahn, and W. Williams (2015): "Women in science: The path to progress," Scientific American Mind, 26(1), 62-69.

Chari, A., and P. Goldsmith-Pinkham (2017): "Gender Representation in Economics Across Topics and Time: Evidence from the NBER Summer Institute," NBER Working Paper 23953.

Clarke, D., J. P. Romano, and M. Wolf (2019): "The Romano-Wolf Multiple Hypothesis Correction in Stata," IZA Discussion Paper 12845.

Crumb, C. R., C. Moore, And J. Buontempo (2017): "Shifting STEM Stereotypes? Considering the Role of Peer and Teacher Gender," Journal of Research on Adolescence, $27(3), 492-505$.

Dasgupta, N., M. M. Scircle, And M. Hunsinger (2015): "Female peers in small work groups enhance women's motivation, verbal participation, and career aspirations in engineering," Proceedings of the National Academy of Sciences, 112(16), 4988-4993.

DeE, T. S. (2007): "Teachers and the Gender Gaps in Student Achievement," Journal of Human Resources, XLII(3), 528-554.

Dennehy, T. C., And N. Dasgupta (2017): "Female peer mentors early in college increase women's positive academic experiences and retention in engineering," Proceedings of the National Academy of Sciences, 114(23), 5964-5969.

Dupas, P., A. Modestino, M. Niederle, and J. Wolfers (2020): "Gender and the Dynamics of Economics Seminars," Discussion paper, Stanford University.

Dynan, K. E., And C. E. Rouse (1997): "The Underrepresentation of Women in Economics: A Study of Undergraduate Economics Students," The Journal of Economic Education, 28(4), 350-368.

Emerson, T. L. N., K. McGoldrick, and K. J. Mumford (2012): "Women and the Choice to Study Economics," The Journal of Economic Education, 43(4), 349-362.

Finseraas, H., A. A. Johnsen, A. Kotsadam, and G. Torsvik (2016): "Exposure to female colleagues breaks the glass ceiling - Evidence from a combined vignette and field experiment," European Economic Review, 90, 363-374. 
Forscher, P. S., C. K. Lai, J. R. Axt, C. R. Ebersole, M. Herman, P. G. Devine, And B. A. NoseK (2019): "A meta-analysis of procedures to change implicit measures," Journal of Personality and Social Psychology, 117(3), 522-559.

Frank, R. H., T. Gilovich, and D. T. Regan (1993): "Does studying economics inhibit cooperation?," Journal of Economic Perspectives, 7(2), 159-171.

Gatto, J., M. Dambrun, C. Kerbrat, and P. De Oliveira (2010): "Prejudice in the police: On the processes underlying the effects of selection and group socialisation," European Journal of Social Psychology, 40(2), 252-269.

Ginther, D. K., And S. Kahn (2004): "Women in economics: Moving up or falling off the academic career ladder?," Journal of Economic perspectives, 18(3), 193-214.

(2014): "Academic women's careers in the social sciences," in The economics of economists: Institutional setting, individual incentives, and future prospects, ed. by A. Lanteri, and J. Vromen, pp. 285-315. Cambridge University Press, Cambridge.

Glick, P., And S. T. Fiske (1996): "The ambivalent sexism inventory: Differentiating hostile and benevolent sexism.," Journal of personality and social psychology, 70(3), 491512.

Glover, D., A. Pallais, and W. Pariente (2017): "Discrimination as a Self-Fulfilling Prophecy: Evidence from French Grocery Stores," Quarterly Journal of Economics, 132(3), 1219-1260.

Goldin, C. (2015): "Gender and the Undergraduate Economics Major: Notes on the Undergraduate Economics Major at a Highly Selective Liberal Arts College," Discussion paper, Harvard University.

Greenwald, A. G., D. E. McGhee, and J. L. Schwartz (1998): "Measuring individual differences in implicit cognition: the implicit association test.," Journal of personality and social psychology, 74(6), 1464-80.

Grossbard, S., T. Yilmazer, and L. Zhang (2018): "The Gender Gap in Citations: Lessons from Demographic Economic Journals," Discussion Paper 2018-078, HCEO Working Paper.

Haley, H., And J. SidAnius (2005): "Person-organization congruence and the maintenance of group-based social hierarchy: A social dominance perspective," Group Processes E Intergroup Relations, 8(2), 187-203.

Hammock, M. R., P. W. Routon, and J. K. Walker (2016): "The Opinions of Economics Majors before and after Learning Economics," The Journal of Economic Education, 47(1), 76-83.

Heckman, J. J. (1979): "Sample Selection Bias as a Specification Error," Econometrica, $47(1), 153-161$. 
Hengel, E. (2017): "Publishing while Female. Are women held to higher standards? Evidence from peer review," Cambridge Working Papers in Economics 1753, Faculty of Economics, University of Cambridge.

Hospido, L., And C. SAnz (2019): "Gender Gaps in the Evaluation of Research: Evidence from Submissions to Economics Conferences," IZA Discussion Paper 12494.

Inglehart, R. F., And P. Norris (2016): "Trump, Brexit, and the Rise of Populism: Economic Have-Nots and Cultural Backlash," Discussion Paper RWP16-026, Harvard Kennedy School.

Kirkeboen, L. J., E. Leuven, and M. Mogstad (2016): "Field of Study, Earnings, and Self-Selection," The Quarterly Journal of Economics, 131(3), 1057-1111.

Langan, A. (2019): "Female Managers and Gender Disparities: The Case of Academic Department Chairs," Discussion paper, Princeton University.

Larroulet Vignau, C., and M. D. L. L. Domper (2006): "La enseñanza de economía y administración en las instituciones de educación superior," Discussion paper, Universidad del Desarrollo, School of Business and Economics.

LAVY, V. (2008): "Do gender stereotypes reduce girls' or boys' human capital outcomes? Evidence from a natural experiment," Journal of Public Economics, 92(10-11), 20832105.

LeE, D. S. (2009): "Training, Wages, and Sample Selection: Estimating Sharp Bounds on Treatment Effects," The Review of Economic Studies, 76(3), 1071-1102.

Lopez Bohle, S., and L. Paredes Rojas (2007): "Análisis exploratorio de los planes de estudio de Ingeniería Comercial en Chile," Pensamiento $\&$ Gestión, 23, 58-71.

Lucas, A. M., And I. M. Mbiti (2014): "Effects of School Quality on Student Achievement: Discontinuity Evidence from Kenya," American Economic Journal: Applied Economics, 6(3), 234-63.

LundBerg, S. (2018): "Report: Committee on the Status of Women in the Economics Profession (CSWEP)," AEA Papers and Proceedings, 108, 704-21.

— (ed.) (2020): Women in Economics. CEPR Press.

Lundberg, S., And J. Stearns (2019): "Women in Economics: Stalled Progress," Journal of Economic Perspectives, 33(1), 3-22.

Mankiw, N. G. (2011): Principles of Economics. South-Western College Pub; $6^{\text {th }}$ edition.

McConnell, A. R., And J. M. Leibold (2001): "Relations among the Implicit Association Test, Discriminatory Behavior, and Explicit Measures of Racial Attitudes," Journal of Experimental Social Psychology, 37(5), 435-442.

(2009): "Weak criticisms and selective evidence: Reply to Blanton et al. (2009)," Journal of Applied Psychology, 94(3), 583-589. 
Mengel, F., J. Sauermann, and U. Zölitz (2019): "Gender Bias in Teaching Evaluations," Journal of the European Economic Association, 17(2), 535-566.

Mudde, C. (2007): Populist Radical Right Parties in Europe. Cambridge University Press.

NorRis, P. (2005): Radical Right: Voters and Parties in the Electoral Market. Cambridge University Press.

OECD (2018): Education at a Glance 2018: OECD Indicators. OECD Publishing, Paris.

PAREDES, V. (2014): "A teacher like me or a student like me? Role model versus teacher bias effect," Economics of Educacion Review, 39, 38-49.

Pop-Eleches, C., And M. Urquiola (2013): "Going to a Better School: Effects and Behavioral Responses," The American Economic Review, 103(4), 1289-1324.

Porter, C., And D. SERRA (forthcoming): "Gender differences in the choice of major: The importance of female role models," American Economic Journal: Applied Economics.

Romano, J. P., and M. Wolf (2005a): "Exact and Approximate Stepdown Methods for Multiple Hypothesis Testing," Journal of the American Statistical Association, 100(469), 94-108.

(2005b): "Stepwise Multiple Testing as Formalized Data Snooping," Econometrica, $73(4), 1237-1282$.

Rooth, D.-O. (2010): "Automatic associations and discrimination in hiring: Real world evidence," Labour Economics, 17, 523-534.

Rubinstein, A. (2006): "A Sceptic's Comment on the Study of Economics," The Economic Journal, 116(510), C1-C9.

Samuelson, P., and W. Nordhaus (2009): Economics. McGraw-Hill Education; $19^{\text {th }}$ edition.

SARsons, H. (2017): "Recognition for Group Work: Gender Differences in Academia," American Economic Review, 107(5), 141-45.

SiEgfried, J. J. (2014): "Trends in Undergraduate Economics Degrees, 1991-2013," The Journal of Economic Education, 45(4), 387-391.

Stevenson, B., And H. Zlotnik (2018): "Representations of Men and Women in Introductory Economics Textbooks," AEA Papers and Proceedings, 108, 180-85.

Vigneau, E., And E. QAnnari (2003): "Clustering of variables around latent components," Communications in Statistics-Simulation and Computation, 32(4), 1131-1150.

Williams, W. M., AND S. J. CECI (2015): "National hiring experiments reveal 2: 1 faculty preference for women on STEM tenure track," Proceedings of the National Academy of Sciences, p. 201418878. 
Wolfers, J. (2015): "How Economists Came to Dominate the Conversation," https://www.nytimes.com/2015/01/24/upshot/ how-economists-came-to-dominate-the-conversation.html.

Wu, A. (2018): "Gender Stereotype in Academia: Evidence from Economics Job Market Rumors Forum," AEA Papers and Proceedings, 108, 175-179.

ZafAR, B. (2013): "College Major Choice and the Gender Gap," Journal of Human Resources, 48(3), 545-595.

Zimmerman, S. D. (2019): "Elite Colleges and Upward Mobility to Top Jobs and Top Incomes," The American Economic Review, 109(1), 1-47. 


\section{Figures}

Figure 1: Gender attitudes in OECD countries
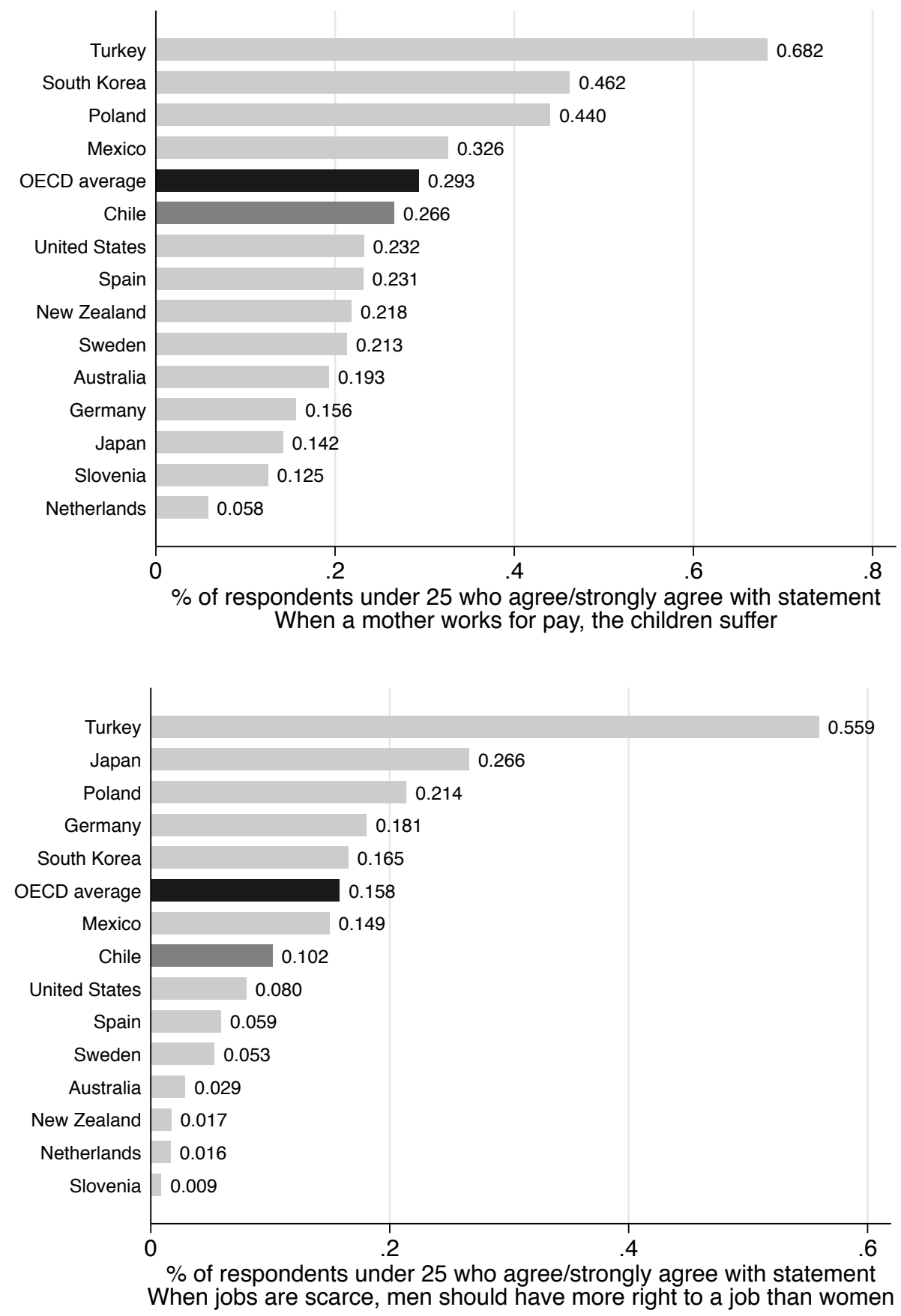
Figure 2: Students enrolled in Higher Education and in Business and Economics

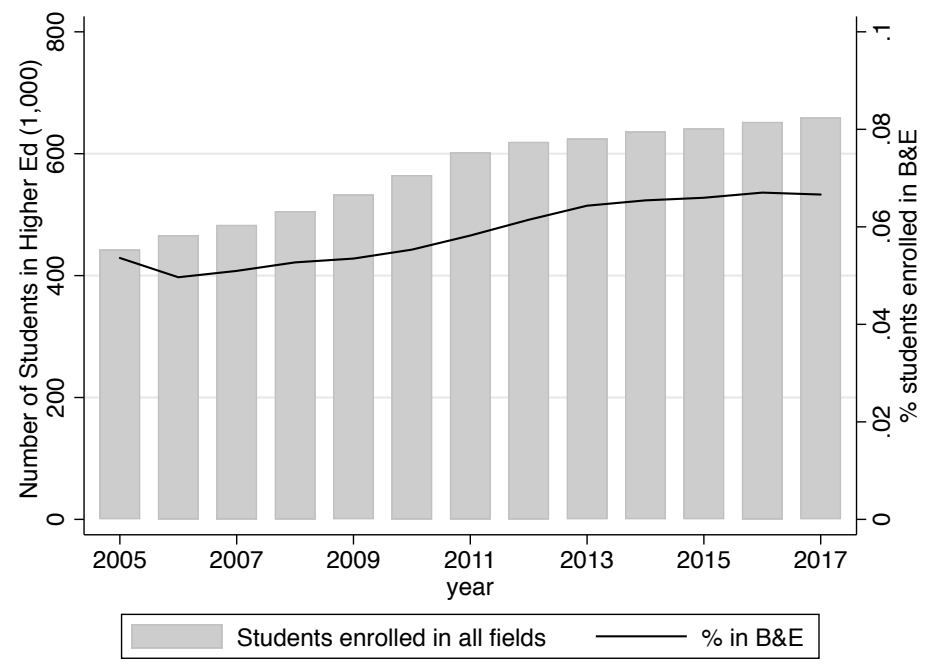

Figure 3: Number of students and percentage of female students in Business and Economics

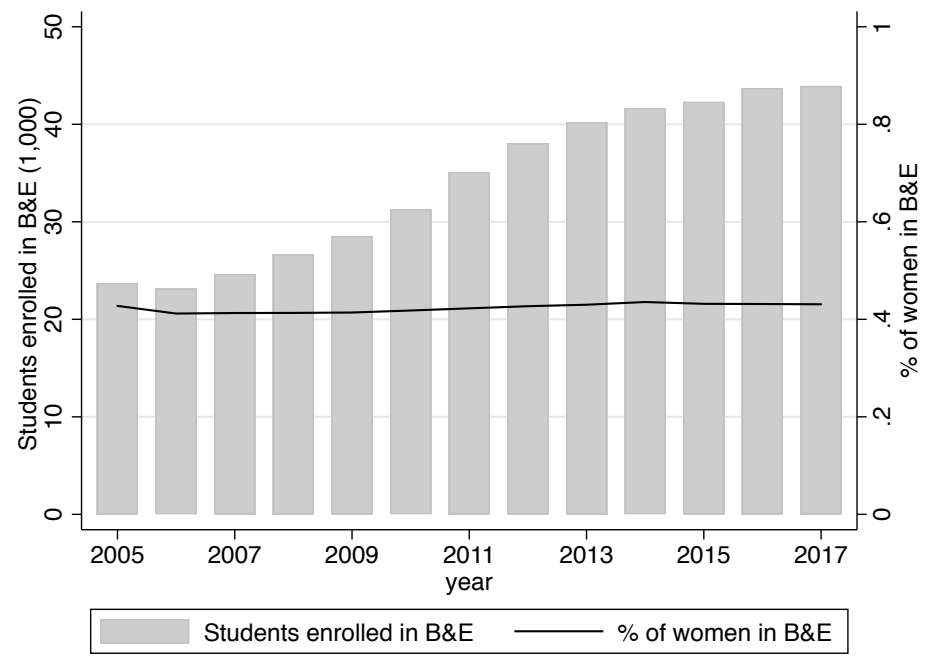


Figure 4: Survey timeline

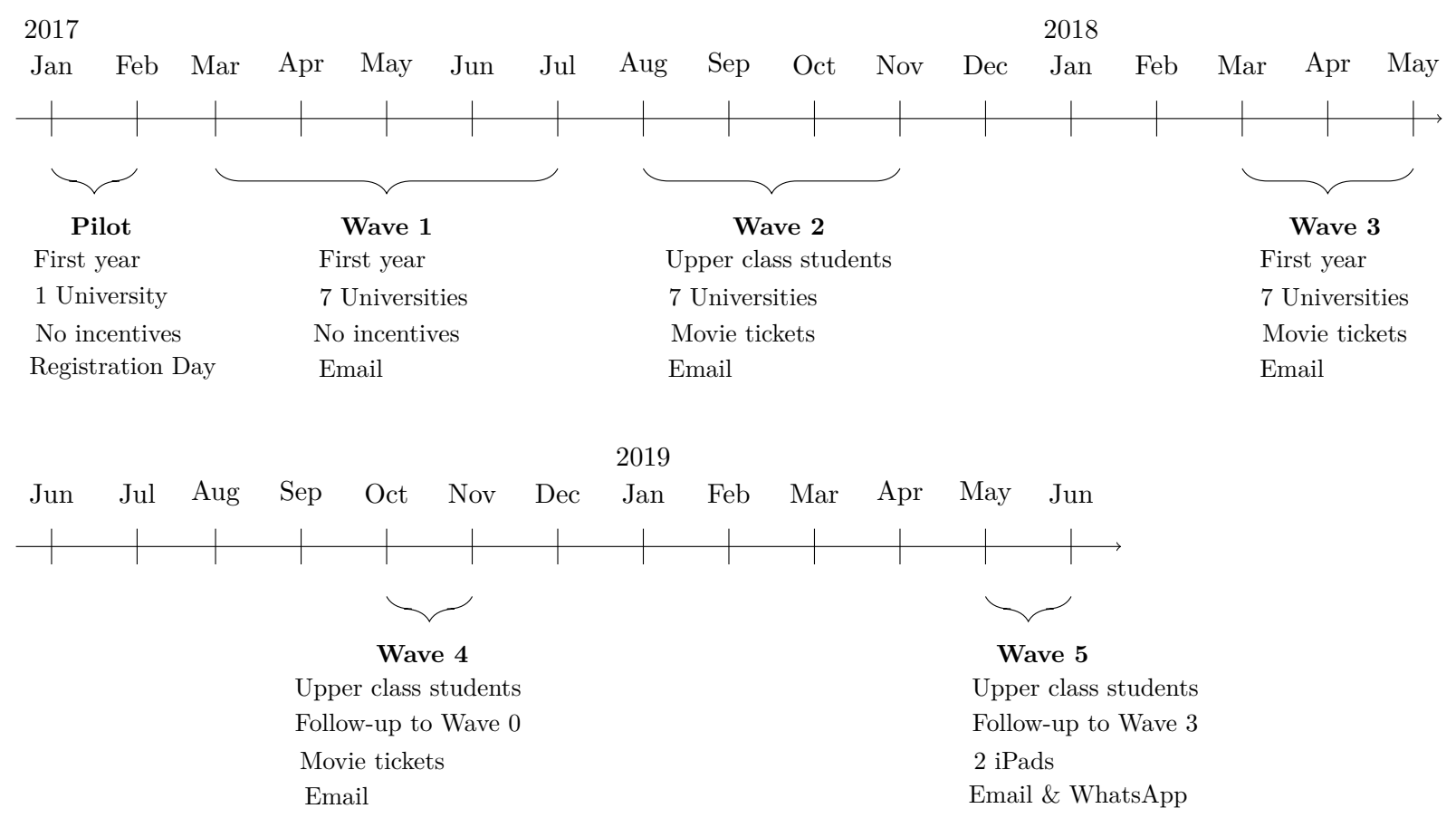

Figure 5: Trends in Score (principal component)

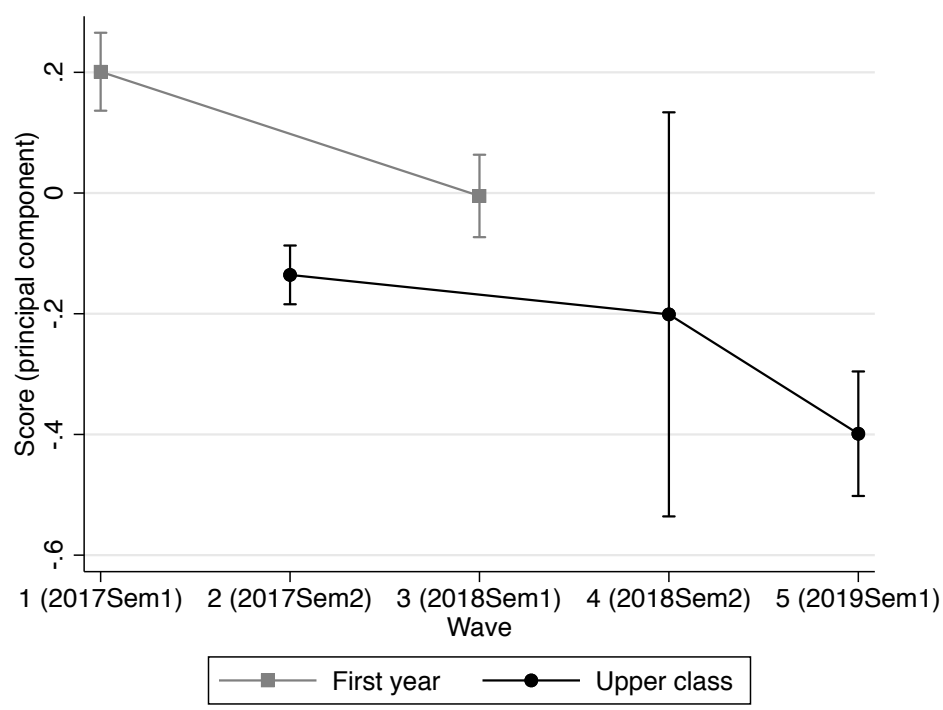


Figure 6: Trends in Hostile Sexism

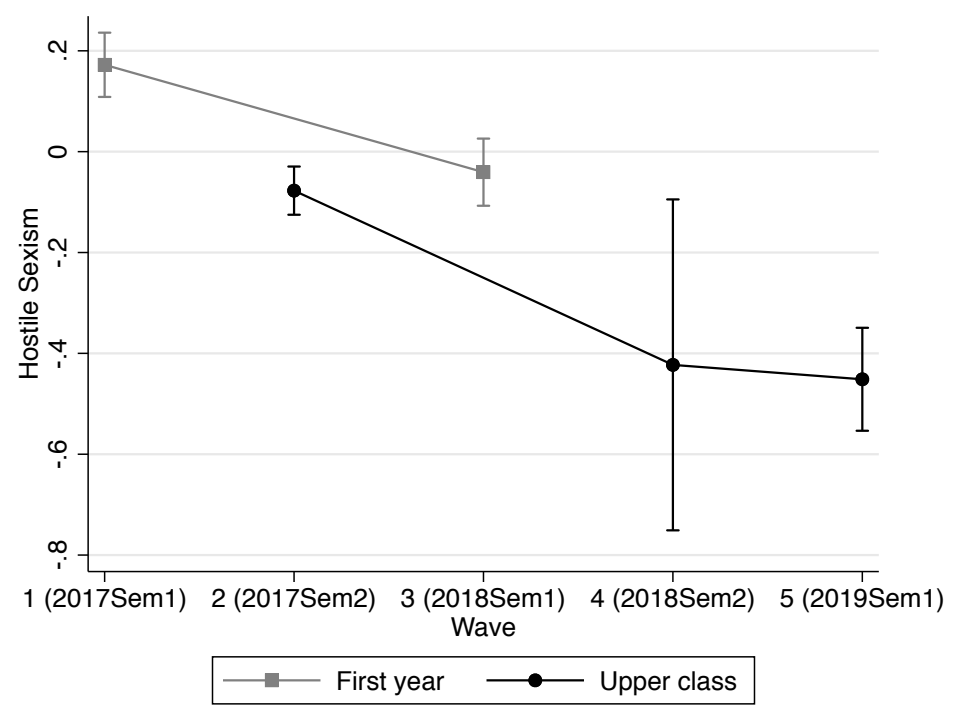

Figure 7: Trends in Gender and Science IAT

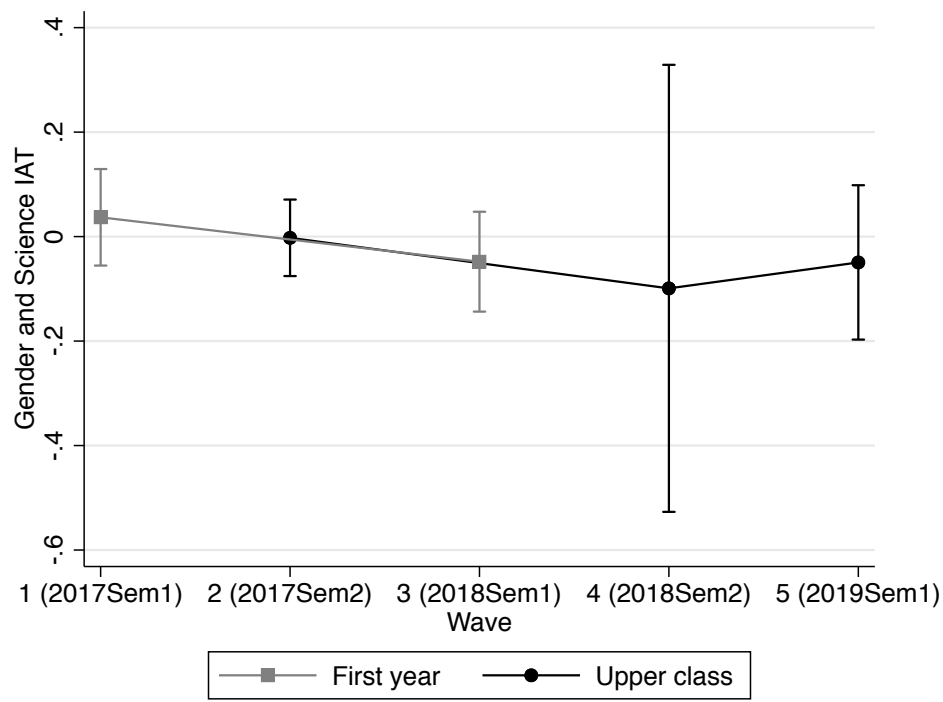




\section{Tables}

Table 1: Number of Students and Fraction B\&E by University

\begin{tabular}{lcccccc}
\hline Wave: & $0-1$ & 2 & 3 & 4 & 5 & Total \\
Date: & Jan-Jul & Aug-Nov & Mar-May & Oct-Nov & May-Jun & \\
& 2017 & 2017 & 2018 & 2018 & 2019 & \\
First year/Upperclass: & First year & Upperclass & First year & Upperclass & Upperclass \\
Follow up: & - & - & - & 0 & 3 & \\
& $(1)$ & $(2)$ & $(3)$ & $(4)$ & $(5)$ & $(6)$ \\
\hline University 1 & 453 & 670 & 443 & 34 & 201 & 1,801 \\
& {$[26.05]$} & {$[23.28]$} & {$[19.86]$} & {$[58.82]$} & {$[17.41]$} & {$[23.15]$} \\
University 2 & 97 & 200 & 45 & & 17 & 359 \\
& {$[39.18]$} & {$[56.00]$} & {$[2.22]$} & & {$[5.88]$} & {$[42.34]$} \\
University 3 & 86 & 182 & 26 & & 11 & 305 \\
& {$[9.30]$} & {$[18.68]$} & {$[53.85]$} & & {$[45.45]$} & {$[20.00]$} \\
University 4 & 102 & 175 & 131 & & 47 & 455 \\
& {$[30.39]$} & {$[23.43]$} & {$[32.82]$} & & {$[38.30]$} & {$[29.23]$} \\
University 5 & 45 & 31 & 11 & & 1 & 88 \\
& {$[15.56]$} & {$[38.71]$} & {$[0.00]$} & & {$[0.00]$} & {$[21.59]$} \\
University 6 & 86 & 145 & 97 & & 28 & 356 \\
& {$[18.60]$} & {$[8.97]$} & {$[16.49]$} & & {$[7.14]$} & {$[13.20]$} \\
University 7 & 47 & 107 & 93 & & 27 & 274 \\
& {$[48.94]$} & {$[36.45]$} & {$[31.18]$} & & {$[22.22]$} & {$[35.40]$} \\
Other universities & 49 & 18 & 5 & & 13 & 85 \\
& {$[63.27]$} & {$[38.89]$} & {$[0.00]$} & & {$[7.69]$} & {$[45.88]$} \\
\hline Total & 965 & 1,528 & 851 & 34 & 345 & 3.723 \\
& {$[28.19]$} & {$[27.09]$} & {$[22.44]$} & {$[58.82]$} & {$[19.71]$} & {$[25.92]$} \\
\hline
\end{tabular}

Notes: First year includes students enrolled in first year, while Upperclass includes students enrolled in years 2 to 6 . Wave 4 corresponds to a follow-up to students surveyed in wave 0 and wave 5 corresponds to a follow-up to students surveyed in wave 3. The percentage of students in Business \& Economics is presented in square brackets. 
Table 2: Number and Percentage of Students by Field of Study

\begin{tabular}{lcccccc}
\hline Wave: & $0-1$ & 2 & 3 & 4 & 5 & Total \\
Date: & Jan-Jul & Aug-Nov & Mar-May & Oct-Nov & May-Jun & \\
& 2017 & 2017 & 2018 & 2018 & 2019 & \\
First year/Upperclass: & First year & Upperclass & First year & Upperclass & Upperclass & \\
Follow up: & - & - & - & 0 & 3 & \\
& $(1)$ & $(2)$ & $(3)$ & $(4)$ & $(5)$ & $(6)$ \\
\hline Accounting & 131 & 137 & 125 & 13 & 37 & 443 \\
& {$[13.58]$} & {$[8.97]$} & {$[14.69]$} & {$[38.24]$} & {$[10.72]$} & {$[11.9]$} \\
Economics & 272 & 414 & 191 & 20 & 68 & 965 \\
& {$[28.19]$} & {$[27.09]$} & {$[22.44]$} & {$[58.82]$} & {$[19.71]$} & {$[25.92]$} \\
Engineering & 207 & 482 & 190 & 1 & 93 & 973 \\
& {$[21.45]$} & {$[31.54]$} & {$[22.33]$} & {$[2.94]$} & {$[26.96]$} & {$[26.13]$} \\
Law & 85 & 172 & 108 & 0 & 53 & 418 \\
& {$[8.81]$} & {$[11.26]$} & {$[12.69]$} & {$[0.00]$} & {$[15.36]$} & {$[11.23]$} \\
Other & 180 & 163 & 143 & 0 & 62 & 548 \\
& {$[18.65]$} & {$[10.67]$} & {$[16.80]$} & {$[0.00]$} & {$[17.97]$} & {$[14.72]$} \\
Psychology & 34 & 69 & 18 & 0 & 9 & 130 \\
Sciences & {$[3.52]$} & {$[4.52]$} & {$[2.12]$} & {$[0.00]$} & {$[2.61]$} & {$[3.49]$} \\
& 56 & 91 & 76 & 0 & 23 & 246 \\
& {$[5.80]$} & {$[5.96]$} & {$[8.93]$} & {$[0.00]$} & {$[6.67]$} & {$[6.61]$} \\
\hline \multirow{5}{*}{ Total } & & & & & & \\
& 965 & 1,528 & 851 & 34 & 345 & 3,723 \\
& {$[100.00]$} & {$[100.00]$} & {$[100.00]$} & {$[100.00]$} & {$[100.00]$} & {$[100.00]$} \\
\hline
\end{tabular}

Notes: First year includes students enrolled in first year, while Upperclass includes students enrolled in years 2 to 6 . Wave 4 corresponds to a follow-up to students surveyed in wave 0 and wave 5 corresponds to a follow-up to students surveyed in wave 3 . The percentage of students in each field of study is presented in square brackets. 
Table 3: Correlation matrix

\begin{tabular}{|c|c|c|c|c|c|c|c|c|c|}
\hline & $\begin{array}{c}(1) \\
\text { Gender and } \\
\text { science IAT }\end{array}$ & $\begin{array}{c}(2) \\
\text { Gender and } \\
\text { career IAT }\end{array}$ & $\begin{array}{c}(3) \\
\text { Hostile } \\
\text { Sexism }\end{array}$ & $\begin{array}{c}(4) \\
\text { Benevolent } \\
\text { Sexism }\end{array}$ & $\begin{array}{c}(5) \\
\text { Gender roles } \\
\text { traditional } \\
\end{array}$ & $\begin{array}{c}(6) \\
\text { Gender roles } \\
\text { proactive } \\
\end{array}$ & $\begin{array}{c}(7) \\
\text { Gender differences } \\
\text { in math }\end{array}$ & $\begin{array}{c}(8) \\
\text { Gender pay gap due } \\
\text { to discrimination }\end{array}$ & $\begin{array}{c}\text { (9) } \\
\text { Gender pay gap due } \\
\text { to skills and preferences }\end{array}$ \\
\hline $\begin{array}{l}\text { Gender and science } \\
\text { IAT }\end{array}$ & 1 & & & & & & & & \\
\hline $\begin{array}{l}\text { Gender and career } \\
\text { IAT }\end{array}$ & - & 1 & & & & & & & \\
\hline Hostile Sexism & $0.0659^{* *}$ & $0.118^{* * *}$ & 1 & & & & & & \\
\hline Benevolent Sexism & 0.0414 & $0.0887^{* * *}$ & $0.609^{* * *}$ & 1 & & & & & \\
\hline $\begin{array}{l}\text { Gender roles, } \\
\text { traditional }\end{array}$ & 0.0382 & $0.0904^{* * *}$ & $0.567^{* * *}$ & $0.542^{* * *}$ & 1 & & & & \\
\hline $\begin{array}{l}\text { Gender roles, } \\
\text { proactive }\end{array}$ & $0.0609^{*}$ & $0.0754^{* *}$ & $0.367^{* * *}$ & $0.293^{* * *}$ & $0.361^{* * *}$ & 1 & & & \\
\hline $\begin{array}{l}\text { Gender differences } \\
\text { in math }\end{array}$ & $0.0902^{* * *}$ & $0.0699^{* *}$ & $0.444^{* * *}$ & $0.359^{* * *}$ & $0.424^{* * *}$ & $0.254^{* * *}$ & 1 & & \\
\hline $\begin{array}{l}\text { Gender pay gap due } \\
\text { to discrimination }\end{array}$ & 0.0412 & $0.0681^{* *}$ & $0.287^{* * *}$ & $0.194^{* * *}$ & $0.279^{* * *}$ & $0.426^{* * *}$ & $0.186^{* * *}$ & 1 & \\
\hline $\begin{array}{l}\text { Gender pay gap due } \\
\text { to skills and preferences }\end{array}$ & 0.0207 & 0.0235 & $0.277^{* * *}$ & $0.194^{* * *}$ & $0.206^{* * *}$ & $0.0791^{* * *}$ & $0.166^{* * *}$ & $-0.0557^{* * *}$ & 1 \\
\hline Score & $0.142^{* * *}$ & $0.194^{* * *}$ & $0.764^{* * *}$ & $0.690^{* * *}$ & $0.796^{* * *}$ & $0.656^{* * *}$ & $0.653^{* * *}$ & $0.547^{* * *}$ & $0.337^{* * *}$ \\
\hline
\end{tabular}

${ }^{*} p<0.05,{ }^{* *} p<0.01,{ }^{* * *} p<0.001$ 
Table 4: Difference between male and female students

\begin{tabular}{lcccc}
\hline Sample: & Female students & Male Students & \multicolumn{2}{c}{ Difference } \\
& $(1)$ & $(2)$ & $(3)$ & $(4)$ \\
\hline IATscience & -0.115 & 0.128 & $0.243^{*}$ & 0.199 \\
& & & $(0.130)$ & $(0.163)$ \\
IATcareer & -0.016 & 0.019 & 0.035 & 0.055 \\
& & & $(0.045)$ & $(0.047)$ \\
Hostile & -0.286 & 0.298 & $0.584^{* * *}$ & $0.586^{* * *}$ \\
& & & $(0.038)$ & $(0.045)$ \\
Benevolent & -0.254 & 0.265 & $0.518^{* * *}$ & $0.522^{* * *}$ \\
& & & $(0.033)$ & $(0.031)$ \\
Roles: traditional & -0.246 & 0.246 & $0.493^{* * *}$ & $0.466^{* * *}$ \\
& & & $(0.050)$ & $(0.040)$ \\
Roles: normative & -0.212 & 0.212 & $0.424^{* * *}$ & $0.390^{* * *}$ \\
& & & $(0.032)$ & $(0.047)$ \\
Math & -0.240 & 0.253 & $0.493^{* * *}$ & $0.495^{* * *}$ \\
& & & $(0.040)$ & $(0.038)$ \\
Discrimination & -0.230 & 0.244 & $0.475^{* * *}$ & $0.473^{* * *}$ \\
& & & $(0.033)$ & $(0.046)$ \\
Skill and preferences & 0.002 & -0.013 & -0.015 & 0.023 \\
& & & $(0.039)$ & $(0.037)$ \\
Score & -0.330 & 0.343 & $0.673^{* * *}$ & $0.670^{* * *}$ \\
& & & $(0.039)$ & $(0.039)$ \\
\hline Observations Score & 1,729 & 1,678 & 3,407 & 3,358 \\
Controls & & & no & yes \\
\hline
\end{tabular}

Notes: The sample includes students enrolled in first year in years 2017 and 2018 and students enrolled in years 2 to 6 who were surveyed in 2017, 2018 and 2019. Column 1 shows the mean of each dependent variable for female students and Column 2 shows the mean for male students. In columns 3-4, each coefficient comes from a separate regression of the dependent variable on a dummy for male students. Controls are dummies for mother's education, working mother, school type (private, public, voucher), education type (mixed, single-sex school, single-sex classroom), highschool GPA, college admission test scores (PSU) and university dummies. Standard errors, clustered at the university/major level, are presented in parentheses. $* * *, * *$ and $*$ indicate statistical significance at the $99 \%, 95 \%$ and $90 \%$, respectively. 
Table 5: Are economic students more sexist than other students?

\begin{tabular}{|c|c|c|c|c|c|c|}
\hline \multirow[t]{2}{*}{ Sample: } & \multirow{2}{*}{$\begin{array}{c}\text { B\&E students } \\
\text { (1) }\end{array}$} & \multirow{2}{*}{$\begin{array}{c}\text { Other Students } \\
(2) \\
\end{array}$} & \multicolumn{4}{|c|}{ Difference } \\
\hline & & & \multicolumn{2}{|c|}{ All students } & $\begin{array}{c}\text { Male } \\
(5)\end{array}$ & $\begin{array}{c}\text { Female } \\
(6)\end{array}$ \\
\hline IATscience & 0.090 & -0.036 & $\begin{array}{l}0.127^{* *} \\
(0.063)\end{array}$ & $\begin{array}{c}0.050 \\
(0.048)\end{array}$ & $\begin{array}{l}-0.046 \\
(0.074)\end{array}$ & $\begin{array}{l}0.184^{*} \\
(0.107)\end{array}$ \\
\hline IATcareer & 0.126 & -0.044 & $\begin{array}{c}0.170^{* * *} \\
(0.041)\end{array}$ & $\begin{array}{c}0.145^{* * *} \\
(0.037)\end{array}$ & $\begin{array}{c}0.231^{* * *} \\
(0.056)\end{array}$ & $\begin{array}{l}0.054 \\
(0.049)\end{array}$ \\
\hline Hostile & 0.128 & -0.041 & $\begin{array}{c}0.169 \\
(0.116)\end{array}$ & $\begin{array}{c}0.147^{* * *} \\
(0.054)\end{array}$ & $\begin{array}{c}0.157^{* *} \\
(0.061)\end{array}$ & $\begin{array}{c}0.146^{* *} \\
(0.062)\end{array}$ \\
\hline Benevolent & 0.146 & -0.049 & $\begin{array}{l}0.194^{* *} \\
(0.091)\end{array}$ & $\begin{array}{c}0.152^{* * *} \\
(0.052)\end{array}$ & $\begin{array}{c}0.153^{* *} \\
(0.070)\end{array}$ & $\begin{array}{c}0.157^{* * *} \\
(0.056)\end{array}$ \\
\hline Roles: traditional & 0.067 & -0.022 & $\begin{array}{c}0.089 \\
(0.086)\end{array}$ & $\begin{array}{c}0.057 \\
(0.049)\end{array}$ & $\begin{array}{c}0.074 \\
(0.052)\end{array}$ & $\begin{array}{c}0.063 \\
(0.061)\end{array}$ \\
\hline Roles: normative & 0.135 & -0.046 & $\begin{array}{l}0.181^{* *} \\
(0.072)\end{array}$ & $\begin{array}{l}0.110^{* *} \\
(0.041)\end{array}$ & $\begin{array}{l}0.119^{* *} \\
(0.055)\end{array}$ & $\begin{array}{c}0.114^{* *} \\
(0.052)\end{array}$ \\
\hline Math & 0.114 & -0.038 & $\begin{array}{l}0.152^{* *} \\
(0.062)\end{array}$ & $\begin{array}{l}0.102 \\
(0.062)\end{array}$ & $\begin{array}{l}0.168^{* *} \\
(0.079)\end{array}$ & $\begin{array}{c}0.075 \\
(0.046)\end{array}$ \\
\hline Discrimination & 0.009 & -0.003 & $\begin{array}{c}0.012 \\
(0.066)\end{array}$ & $\begin{array}{l}-0.012 \\
(0.044)\end{array}$ & $\begin{array}{l}-0.012 \\
(0.067)\end{array}$ & $\begin{array}{l}-0.015 \\
(0.039)\end{array}$ \\
\hline Skill and preferences & 0.074 & -0.028 & $\begin{array}{c}0.102 \\
(0.067)\end{array}$ & $\begin{array}{l}0.105^{* *} \\
(0.047)\end{array}$ & $\begin{array}{l}0.089^{*} \\
(0.049)\end{array}$ & $\begin{array}{c}0.114 \\
(0.076)\end{array}$ \\
\hline Score & 0.153 & -0.050 & $\begin{array}{l}0.203^{*} \\
(0.107)\end{array}$ & $\begin{array}{c}0.144^{* *} \\
(0.063)\end{array}$ & $\begin{array}{l}0.169^{* *} \\
(0.070)\end{array}$ & $\begin{array}{l}0.145^{* *} \\
(0.071)\end{array}$ \\
\hline $\begin{array}{l}\text { Observations Score } \\
\text { Controls }\end{array}$ & 874 & 2,554 & $\begin{array}{c}3,428 \\
\text { no }\end{array}$ & $\begin{array}{c}3,358 \\
\text { yes }\end{array}$ & $\begin{array}{c}1,651 \\
\text { yes }\end{array}$ & $\begin{array}{c}1,707 \\
\text { yes }\end{array}$ \\
\hline
\end{tabular}

Notes: The sample includes students enrolled in first year in years 2017 and 2018 and students enrolled in years 2 to 6 who were surveyed in 2017, 2018 and 2019. Column 1 shows the mean of each dependent variable for B\&E students students and Column 2 shows the mean for students in other fields. In columns 3-6, each coefficient comes from a separate regression of the dependent variable on a dummy for whether the student is enrolled in B\&E. Controls are female, dummies for mother's education, working mother, school type (private, public, voucher), education type (mixed, single-sex school, single-sex classroom), highschool GPA, college admission test scores (PSU) and university dummies. Standard errors, clustered at the university/major level, are presented in parentheses. ${ }^{* * *},{ }^{* *}$ and $*$ indicate statistical significance at the $99 \%, 95 \%$ and $90 \%$, respectively. 
Table 6: Are there differences in background characteristics between economic and non economic students?

\begin{tabular}{|c|c|c|c|}
\hline Sample: & $\begin{array}{c}\text { First year } \\
\text { (1) }\end{array}$ & $\begin{array}{c}\text { Upperclass } \\
(2)\end{array}$ & $\begin{array}{c}\text { Dif-in-Dif } \\
(3)\end{array}$ \\
\hline Female student & $\begin{array}{l}-0.051 \\
(0.059)\end{array}$ & $\begin{array}{l}-0.042 \\
(0.052)\end{array}$ & $\begin{array}{c}0.008 \\
(0.035)\end{array}$ \\
\hline Mother years of schooling & $\begin{array}{c}0.262 \\
(0.587)\end{array}$ & $\begin{array}{c}0.475 \\
(0.499)\end{array}$ & $\begin{array}{c}0.213 \\
(0.379)\end{array}$ \\
\hline Working mother & $\begin{array}{l}-0.027 \\
(0.033)\end{array}$ & $\begin{array}{l}-0.010 \\
(0.028)\end{array}$ & $\begin{array}{c}0.016 \\
(0.026)\end{array}$ \\
\hline Single-sex school & $\begin{array}{c}0.039 \\
(0.044)\end{array}$ & $\begin{array}{c}0.013 \\
(0.039)\end{array}$ & $\begin{array}{l}-0.026 \\
(0.030)\end{array}$ \\
\hline Single-sex classroom & $\begin{array}{c}0.012 \\
(0.010)\end{array}$ & $\begin{array}{c}0.002 \\
(0.003)\end{array}$ & $\begin{array}{l}-0.010 \\
(0.008)\end{array}$ \\
\hline Coeducational school & $\begin{array}{l}-0.056 \\
(0.053)\end{array}$ & $\begin{array}{c}-0.020 \\
(0.039)\end{array}$ & $\begin{array}{c}0.036 \\
(0.035)\end{array}$ \\
\hline Public & $\begin{array}{c}-0.077^{* *} \\
(0.038)\end{array}$ & $\begin{array}{c}-0.102^{* *} \\
(0.049)\end{array}$ & $\begin{array}{l}-0.025 \\
(0.052)\end{array}$ \\
\hline Private school & $\begin{array}{l}0.195^{*} \\
(0.107)\end{array}$ & $\begin{array}{l}0.188^{*} \\
(0.096)\end{array}$ & $\begin{array}{l}-0.007 \\
(0.079)\end{array}$ \\
\hline Voucher school & $\begin{array}{c}-0.120 \\
(0.080)\end{array}$ & $\begin{array}{c}-0.094 \\
(0.069)\end{array}$ & $\begin{array}{c}0.026 \\
(0.043)\end{array}$ \\
\hline PSU math & $\begin{array}{c}19.973 \\
(28.293)\end{array}$ & $\begin{array}{c}22.059 \\
(29.162)\end{array}$ & $\begin{array}{c}2.086 \\
(12.209)\end{array}$ \\
\hline High school gpa & $\begin{array}{c}-0.694 \\
(21.659)\end{array}$ & $\begin{array}{c}1.995 \\
(21.737)\end{array}$ & $\begin{array}{c}2.689 \\
(9.238)\end{array}$ \\
\hline Controls & no & no & no \\
\hline
\end{tabular}

Notes: First year includes students enrolled in first year in years 2017 and 2018, while Upperclass includes students enrolled in years 2 to 6 who were surveyed in 2017, 2018 and 2019. In columns 1 and 2, each coefficient comes from a separate regression of the dependent variable (specified in each row) on a dummy for whether the student is enrolled in Business \& Economics (B\&E). In column 3 each coefficient comes from a separate regression of the dependent variable on the interaction of B\&E and an indicator of Upperclass. Standard errors, clustered at the university/major level, are presented in parentheses. ${ }^{* * *},{ }^{* *}$ and ${ }^{*}$ indicate statistical significance at the $99 \%, 95 \%$ and $90 \%$, respectively. 
Table 7a: Economics and gender biases, selection or treatment effect? All students

\begin{tabular}{lccc}
\hline \multirow{3}{*}{ Sample: } & \multicolumn{3}{c}{ All students } \\
\cline { 2 - 4 } & First year & Upperclass & Dif-in-Dif \\
& $(1)$ & $(2)$ & $(3)$ \\
\hline IATscience & 0.037 & 0.065 & 0.028 \\
IATcareer & $(0.066)$ & $(0.055)$ & $(0.061)$ \\
& 0.081 & $0.193^{* * *}$ & 0.112 \\
Hostile & $(0.061)$ & $(0.046)$ & $(0.076)$ \\
Benevolent & $0.146^{* *}$ & $0.168^{* *}$ & 0.022 \\
& $(0.060)$ & $(0.071)$ & $(0.063)$ \\
Roles: traditional & $0.123^{*}$ & $0.192^{* * *}$ & 0.069 \\
& $(0.066)$ & $(0.054)$ & $(0.057)$ \\
Roles: normative & 0.061 & 0.070 & 0.009 \\
Math & $0.055)$ & $(0.062)$ & $(0.063)$ \\
& $0.115^{* * *}$ & $0.137^{*}$ & 0.022 \\
Discrimination & $(0.039)$ & $(0.071)$ & $(0.073)$ \\
Skill and preferences & $0.072^{* *}$ & 0.135 & 0.063 \\
& $(0.031)$ & $(0.095)$ & $(0.076)$ \\
Score & -0.030 & 0.014 & 0.044 \\
& $(0.049)$ & $(0.059)$ & $(0.064)$ \\
& $(0.069)$ & $0.116^{*}$ & -0.003 \\
Observations Score & $(0.064)$ & $(0.092)$ \\
Controls & $0.106^{*}$ & $0.199^{* *}$ & 0.092 \\
\hline & $(0.059)$ & $(0.089)$ & $(0.080)$ \\
\hline
\end{tabular}

Notes: First year includes students enrolled in first year in years 2017 and 2018, while Upperclass includes students enrolled in years 2 to 6 who were surveyed in 2017, 2018 and 2019. In columns 1, 2, 4, 5, 7 and 8, each coefficient comes from a separate regression of the dependent variable on a dummy for whether the student is enrolled in Business \& Economics (B\&E). In columns 3, 6 and 9 each coefficient comes from a separate regression of the dependent variable on the interaction of $\mathrm{B} \& \mathrm{E}$ and an indicator of Upperclass. Controls are female, dummies for mother's education, working mother, school type (private, public, voucher), education type (mixed, single-sex school, single-sex classroom), highschool GPA, college admission test scores (PSU) and university dummies. Standard errors, clustered at the university/major level, are presented in parentheses. ${ }^{* * *},{ }^{* *}$ and ${ }^{*}$ indicate statistical significance at the $99 \%, 95 \%$ and $90 \%$, respectively. 
Table 7b: Economics and gender biases, selection or treatment effect? Male and female students

\begin{tabular}{|c|c|c|c|c|c|c|}
\hline \multirow[b]{2}{*}{ Sample: } & \multicolumn{3}{|c|}{ Male students } & \multicolumn{3}{|c|}{ Female students } \\
\hline & $\begin{array}{c}\text { First year } \\
\text { (4) }\end{array}$ & $\begin{array}{c}\text { Upperclass } \\
(5)\end{array}$ & $\begin{array}{l}\text { Dif-in-Dif } \\
(6)\end{array}$ & $\begin{array}{c}\text { First year } \\
(7)\end{array}$ & $\begin{array}{c}\text { Upperclass } \\
(8)\end{array}$ & $\begin{array}{c}\text { Dif-in-Dif } \\
\quad(9)\end{array}$ \\
\hline IATscience & $\begin{array}{l}-0.055 \\
(0.133)\end{array}$ & $\begin{array}{c}-0.053 \\
(0.071)\end{array}$ & $\begin{array}{c}0.002 \\
(0.115)\end{array}$ & $\begin{array}{c}0.141 \\
(0.108)\end{array}$ & $\begin{array}{l}0.243^{*} \\
(0.141)\end{array}$ & $\begin{array}{c}0.102 \\
(0.134)\end{array}$ \\
\hline IATcareer & $\begin{array}{c}0.188 \\
(0.113)\end{array}$ & $\begin{array}{c}0.263^{* * *} \\
(0.076)\end{array}$ & $\begin{array}{l}0.075 \\
(0.157)\end{array}$ & $\begin{array}{l}-0.036 \\
(0.072)\end{array}$ & $\begin{array}{c}0.119 \\
(0.106)\end{array}$ & $\begin{array}{c}0.155 \\
(0.148)\end{array}$ \\
\hline Hostile & $\begin{array}{c}0.122 \\
(0.077)\end{array}$ & $\begin{array}{c}0.222^{* * * *} \\
(0.079)\end{array}$ & $\begin{array}{c}0.100 \\
(0.087)\end{array}$ & $\begin{array}{c}0.161^{* *} \\
(0.062)\end{array}$ & $\begin{array}{l}0.149^{*} \\
(0.085)\end{array}$ & $\begin{array}{l}-0.013 \\
(0.072)\end{array}$ \\
\hline Benevolent & $\begin{array}{c}0.066 \\
(0.079)\end{array}$ & $\begin{array}{c}0.263^{* * * *} \\
(0.078)\end{array}$ & $\begin{array}{c}0.197^{* *} \\
(0.078)\end{array}$ & $\begin{array}{c}0.178^{* *} \\
(0.068)\end{array}$ & $\begin{array}{l}0.145^{*} \\
(0.080)\end{array}$ & $\begin{array}{l}-0.034 \\
(0.092)\end{array}$ \\
\hline Roles: traditional & $\begin{array}{c}0.072 \\
(0.057)\end{array}$ & $\begin{array}{c}0.113 \\
(0.070)\end{array}$ & $\begin{array}{c}0.040 \\
(0.073)\end{array}$ & $\begin{array}{c}0.072 \\
(0.074)\end{array}$ & $\begin{array}{c}0.054 \\
(0.078)\end{array}$ & $\begin{array}{l}-0.018 \\
(0.091)\end{array}$ \\
\hline Roles: normative & $\begin{array}{l}0.089^{*} \\
(0.053)\end{array}$ & $\begin{array}{l}0.170^{*} \\
(0.086)\end{array}$ & $\begin{array}{c}0.081 \\
(0.086)\end{array}$ & $\begin{array}{c}0.152^{* *} \\
(0.061)\end{array}$ & $\begin{array}{c}0.124 \\
(0.078)\end{array}$ & $\begin{array}{l}-0.029 \\
(0.078)\end{array}$ \\
\hline Math & $\begin{array}{c}0.144^{* *} \\
(0.056)\end{array}$ & $\begin{array}{l}0.195^{*} \\
(0.114)\end{array}$ & $\begin{array}{c}0.052 \\
(0.078)\end{array}$ & $\begin{array}{c}0.019 \\
(0.062)\end{array}$ & $\begin{array}{c}0.126 \\
(0.084)\end{array}$ & $\begin{array}{c}0.107 \\
(0.120)\end{array}$ \\
\hline Discrimination & $\begin{array}{l}-0.094 \\
(0.060)\end{array}$ & $\begin{array}{c}0.069 \\
(0.093)\end{array}$ & $\begin{array}{l}0.164^{*} \\
(0.086)\end{array}$ & $\begin{array}{c}0.022 \\
(0.058)\end{array}$ & $\begin{array}{l}-0.023 \\
(0.067)\end{array}$ & $\begin{array}{l}-0.045 \\
(0.095)\end{array}$ \\
\hline Skill and preferences & $\begin{array}{c}0.124 \\
(0.080)\end{array}$ & $\begin{array}{c}0.066 \\
(0.069)\end{array}$ & $\begin{array}{l}-0.058 \\
(0.110)\end{array}$ & $\begin{array}{c}0.089 \\
(0.107)\end{array}$ & $\begin{array}{c}0.147 \\
(0.091)\end{array}$ & $\begin{array}{c}0.059 \\
(0.114)\end{array}$ \\
\hline Score & $\begin{array}{c}0.085 \\
(0.065)\end{array}$ & $\begin{array}{c}0.269^{* * *} \\
(0.092)\end{array}$ & $\begin{array}{c}0.183^{* *} \\
(0.074)\end{array}$ & $\begin{array}{l}0.137^{*} \\
(0.079)\end{array}$ & $\begin{array}{c}0.172 \\
(0.109)\end{array}$ & $\begin{array}{c}0.035 \\
(0.121)\end{array}$ \\
\hline $\begin{array}{l}\text { Observations Score } \\
\text { Controls }\end{array}$ & $\begin{array}{l}772 \\
\text { yes }\end{array}$ & $\begin{array}{l}879 \\
\text { yes }\end{array}$ & $\begin{array}{c}1651 \\
\text { yes }\end{array}$ & $\begin{array}{l}784 \\
\text { yes }\end{array}$ & $\begin{array}{l}923 \\
\text { yes }\end{array}$ & $\begin{array}{c}1707 \\
\text { yes }\end{array}$ \\
\hline
\end{tabular}

Notes: First year includes students enrolled in first year in years 2017 and 2018, while Upperclass includes students enrolled in years 2 to 6 who were surveyed in 2017, 2018 and 2019. In columns 1, 2, 4, 5, 7 and 8, each coefficient comes from a separate regression of the dependent variable on a dummy for whether the student is enrolled in Business \& Economics (B\&E). In columns 3, 6 and 9 each coefficient comes from a separate regression of the dependent variable on the interaction of $\mathrm{B} \& \mathrm{E}$ and an indicator of Upperclass. Controls are female, dummies for mother's education, working mother, school type (private, public, voucher), education type (mixed, single-sex school, single-sex classroom), highschool GPA, college admission test scores (PSU) and university dummies. Standard errors, clustered at the university/major level, are presented in parentheses. ${ }^{* * *},{ }^{* *}$ and ${ }^{*}$ indicate statistical significance at the $99 \%, 95 \%$ and $90 \%$, respectively. 
Table 8a: Gender Bias and Economics - Panel Data, all students

\begin{tabular}{lccccc}
\hline \multirow{4}{*}{ Sample: } & \multicolumn{5}{c}{ All } \\
\cline { 2 - 6 } & 1st year & 2nd Year & DiD & DiD-FD & Heckman \\
& $(1)$ & $(2)$ & $(3)$ & $(4)$ & $(5)$ \\
\hline IATscience & 0.032 & -0.022 & -0.054 & 0.004 & -0.052 \\
IATcareer & $(0.136)$ & $(0.170)$ & $(0.212)$ & $(0.212)$ & $(0.212)$ \\
& $0.298^{* * *}$ & 0.030 & $-0.268^{*}$ & 0.179 & -0.182 \\
Hostile & $(0.061)$ & $(0.128)$ & $(0.150)$ & $(0.182)$ & $(0.306)$ \\
& 0.011 & 0.078 & 0.067 & 0.043 & 0.183 \\
Benevolent & $(0.124)$ & $(0.093)$ & $(0.117)$ & $(0.118)$ & $(0.144)$ \\
& -0.009 & 0.143 & $0.153^{*}$ & 0.057 & 0.156 \\
Roles: traditional & $(0.080)$ & $(0.090)$ & $(0.083)$ & $(0.142)$ & $(0.112)$ \\
& -0.018 & -0.045 & -0.026 & $-0.134^{* *}$ & -0.051 \\
Roles: normative & $(0.064)$ & $(0.070)$ & $(0.073)$ & $(0.060)$ & $(0.074)$ \\
Math & 0.048 & 0.036 & -0.012 & -0.179 & -0.092 \\
& $(0.092)$ & $(0.072)$ & $(0.151)$ & $(0.194)$ & $(0.183)$ \\
Discrimination & 0.084 & $0.224^{* *}$ & $0.140^{*}$ & 0.130 & $0.204^{* * *}$ \\
Skill and preferences & $-0.060)$ & $(0.108)$ & $(0.074)$ & $(0.080)$ & $(0.071)$ \\
& $-0.208^{* *}$ & 0.083 & $0.291^{*}$ & $0.229^{* * *}$ & $0.318^{* * *}$ \\
Score & $(0.088)$ & $(0.123)$ & $(0.150)$ & $(0.075)$ & $(0.068)$ \\
& $(0.085)$ & 0.058 & 0.177 & $0.220^{* *}$ & $0.280^{* *}$ \\
& -0.071 & 0.089 & $(0.148)$ & $(0.107)$ & $(0.141)$ \\
Observations Score & $(0.065)$ & $(0.109)$ & $(0.160$ & 0.112 & $0.179^{* * *}$ \\
\hline Controls & 301 & 305 & 606 & $(0.086)$ & $(0.065)$ \\
Student FE & yes & yes & yes & no & no \\
\hline
\end{tabular}

Notes: First year includes students enrolled in first year in years 2017 and 2018, while Second year includes students enrolled in second year who were surveyed in 2018 and 2019. In columns 1 and 2, each coefficient comes from a separate regression of the dependent variable on a dummy for whether the student is enrolled in Business \& Economics (B\&E). In columns 3-9 each coefficient comes from a separate regression of the dependent variable on the interaction of $\mathrm{B} \& \mathrm{E}$ and an indicator of Upperclass. Columns 4, 6 and 8 are estimated in first differences. In columns 5, 7 and 9, we use a heckman selection model to correct for attrition bias in the model with student fixed effect. Variables included in the selection model are a dummy for whether the student is enrolled in Business \& Economics (B\&E), the score in either wave 0 or 3 , and a dummy for whether the student gave their contact phone in addition to their contact email. Controls are female, dummies for mother's education, working mother, school type (private, public, voucher), education type (mixed, single-sex school, single-sex classroom), highschool GPA, college admission test scores (PSU) and university dummies. Standard errors, clustered at the university/major level, are presented in parentheses. ${ }^{* * *},{ }^{* *}$ and $*$ indicate statistical significance at the $99 \%, 95 \%$ and $90 \%$, respectively. 
Table 8b: Gender Bias and Economics - Panel Data, male and female students

\begin{tabular}{|c|c|c|c|c|}
\hline \multirow[b]{2}{*}{ Sample: } & \multicolumn{2}{|c|}{ Male students } & \multicolumn{2}{|c|}{ Female students } \\
\hline & $\begin{array}{c}\text { DiD-FD } \\
(6)\end{array}$ & $\begin{array}{c}\text { Heckman } \\
(7)\end{array}$ & $\begin{array}{c}\text { DiD-FD } \\
(8)\end{array}$ & $\begin{array}{c}\text { Heckman } \\
\quad(9)\end{array}$ \\
\hline IATscience & $\begin{array}{c}0.016 \\
(0.317)\end{array}$ & $\begin{array}{l}-0.069 \\
(0.278)\end{array}$ & $\begin{array}{l}-0.108 \\
(0.246)\end{array}$ & $\begin{array}{l}-0.118 \\
(0.271)\end{array}$ \\
\hline IATcareer & $\begin{array}{c}0.042 \\
(0.236)\end{array}$ & $\begin{array}{c}0.103 \\
(0.252)\end{array}$ & $\begin{array}{c}0.296 \\
(0.208)\end{array}$ & $\begin{array}{c}0.106 \\
(0.332)\end{array}$ \\
\hline Hostile & $\begin{array}{c}0.094 \\
(0.124)\end{array}$ & $\begin{array}{c}0.204 \\
(0.157)\end{array}$ & $\begin{array}{l}-0.003 \\
(0.151)\end{array}$ & $\begin{array}{c}0.065 \\
(0.156)\end{array}$ \\
\hline Benevolent & $\begin{array}{c}0.244 \\
(0.214)\end{array}$ & $\begin{array}{c}0.328^{* *} \\
(0.153)\end{array}$ & $\begin{array}{l}-0.109 \\
(0.127)\end{array}$ & $\begin{array}{c}-0.072 \\
(0.132)\end{array}$ \\
\hline Roles: traditional & $\begin{array}{c}-0.199^{*} \\
(0.103)\end{array}$ & $\begin{array}{l}-0.097 \\
(0.132)\end{array}$ & $\begin{array}{l}-0.079 \\
(0.092)\end{array}$ & $\begin{array}{c}0.005 \\
(0.087)\end{array}$ \\
\hline Roles: normative & $\begin{array}{l}-0.053 \\
(0.164)\end{array}$ & $\begin{array}{l}-0.004 \\
(0.194)\end{array}$ & $\begin{array}{l}-0.295 \\
(0.212)\end{array}$ & $\begin{array}{l}-0.188 \\
(0.180)\end{array}$ \\
\hline Math & $\begin{array}{c}0.076 \\
(0.087)\end{array}$ & $\begin{array}{c}0.106 \\
(0.098)\end{array}$ & $\begin{array}{c}0.219 \\
(0.152)\end{array}$ & $\begin{array}{c}0.365^{* * *} \\
(0.125)\end{array}$ \\
\hline Discrimination & $\begin{array}{c}0.183 \\
(0.127)\end{array}$ & $\begin{array}{c}0.335^{* *} \\
(0.139)\end{array}$ & $\begin{array}{l}0.248^{*} \\
(0.124)\end{array}$ & $\begin{array}{c}0.294^{* *} \\
(0.128)\end{array}$ \\
\hline Skill and preferences & $\begin{array}{c}0.221^{* *} \\
(0.101)\end{array}$ & $\begin{array}{c}0.299^{* *} \\
(0.133)\end{array}$ & $\begin{array}{c}0.217 \\
(0.170)\end{array}$ & $\begin{array}{c}0.074 \\
(0.202)\end{array}$ \\
\hline Score & $\begin{array}{c}0.132 \\
(0.095)\end{array}$ & $\begin{array}{c}0.197^{* *} \\
(0.091)\end{array}$ & $\begin{array}{c}0.093 \\
(0.134)\end{array}$ & $\begin{array}{c}0.167 \\
(0.130)\end{array}$ \\
\hline Observations Score & 129 & 383 & 162 & 379 \\
\hline $\begin{array}{l}\text { Controls } \\
\text { Student FE }\end{array}$ & $\begin{array}{l}\text { no } \\
\text { yes }\end{array}$ & $\begin{array}{c}\text { no } \\
\text { yes }\end{array}$ & $\begin{array}{l}\text { no } \\
\text { yes }\end{array}$ & $\begin{array}{l}\text { no } \\
\text { yes }\end{array}$ \\
\hline
\end{tabular}

Notes: First year includes students enrolled in first year in years 2017 and 2018, while Second year includes students enrolled in second year who were surveyed in 2018 and 2019. In columns 1 and 2, each coefficient comes from a separate regression of the dependent variable on a dummy for whether the student is enrolled in Business \& Economics (B\&E). In columns 3-9 each coefficient comes from a separate regression of the dependent variable on the interaction of $\mathrm{B} \& \mathrm{E}$ and an indicator of Upperclass. Columns 4,6 and 8 are estimated in first differences. In columns 5,7 and 9 , we use a heckman selection model to correct for attrition bias in the model with student fixed effect. Variables included in the selection model are a dummy for whether the student is enrolled in Business \& Economics (B\&E), the score in either wave 0 or 3 , and a dummy for whether the student gave their contact phone in addition to their contact email. Controls are female, dummies for mother's education, working mother, school type (private, public, voucher), education type (mixed, single-sex school, single-sex classroom), highschool GPA, college admission test scores (PSU) and university dummies. Standard errors, clustered at the university/major level, are presented in parentheses. ${ }^{* * *},{ }^{* *}$ and $*$ indicate statistical significance at the $99 \%, 95 \%$ and $90 \%$, respectively. 
Table 9: Gender Bias and Economics - IV results

\begin{tabular}{|c|c|c|c|}
\hline & $\begin{array}{c}\text { First year } \\
\text { (1) }\end{array}$ & $\begin{array}{c}\text { Upperclass } \\
(2)\end{array}$ & $\begin{array}{c}\text { Dif-in-Dif } \\
(3)\end{array}$ \\
\hline \multirow{3}{*}{$\begin{array}{l}\text { Panel A: All students } \\
\text { Score }\end{array}$} & \multicolumn{3}{|c|}{ 2SLS } \\
\hline & $\begin{array}{c}-0.709 \\
(0.738)\end{array}$ & $\begin{array}{l}-0.052 \\
(0.272)\end{array}$ & $\begin{array}{c}0.657 \\
(0.738)\end{array}$ \\
\hline & \multicolumn{3}{|c|}{ First stage } \\
\hline Above cutoff score & $\begin{array}{c}0.345^{* * *} \\
(0.079)\end{array}$ & \multicolumn{2}{|l|}{$\begin{array}{c}0.413^{* * * *} \\
(0.067)\end{array}$} \\
\hline \multirow{2}{*}{$\begin{array}{l}\text { F-test } \\
\text { Observations }\end{array}$} & 18.968 & \multicolumn{2}{|l|}{38.504} \\
\hline & 439 & 601 & 1040 \\
\hline Panel B: Male students & \multicolumn{3}{|c|}{ 2SLS } \\
\hline \multirow[t]{2}{*}{ Score } & $\begin{array}{c}-0.541 \\
(0.896)\end{array}$ & $\begin{array}{c}0.417 \\
(0.538)\end{array}$ & $\begin{array}{c}0.958 \\
(0.969)\end{array}$ \\
\hline & \multicolumn{3}{|c|}{ First stage } \\
\hline Above cutoff score & $\begin{array}{c}0.423^{* *} \\
(0.176)\end{array}$ & \multicolumn{2}{|l|}{$\begin{array}{c}0.333^{* * *} \\
(0.111)\end{array}$} \\
\hline F-test & 5.742 & \multicolumn{2}{|l|}{8.985} \\
\hline Observations & 236 & 298 & 534 \\
\hline Panel C: Female students & \multicolumn{3}{|c|}{ 2SLS } \\
\hline \multirow[t]{2}{*}{ Score } & $\begin{array}{l}-0.866 \\
(0.887)\end{array}$ & $\begin{array}{l}-0.316 \\
(0.230)\end{array}$ & $\begin{array}{c}0.550 \\
(0.852)\end{array}$ \\
\hline & \multicolumn{3}{|c|}{ First stage } \\
\hline Above cutoff score & $\begin{array}{c}0.331^{* * * *} \\
(0.071)\end{array}$ & $\begin{array}{c}0.505^{* * *} \\
(0.078)\end{array}$ & \\
\hline F-test & 21.889 & 41.729 & \\
\hline Observations & 203 & 303 & 506 \\
\hline
\end{tabular}

Notes: The sample includes students enrolled in first year in years 2017 and 2018 and students enrolled in years 2 to 6 who were surveyed in 2017, 2018 and 2019 and that applied to Business and Economics. In columns 1 and 2 we show the coefficient of an instrumental variable regression of the score on a dummy for whether the student is enrolled in Business \& Economics (B\&E), where B\&E is instrumented by a dummy variable that indicates whether the PSU score is above the threshold for getting into B\&E. In column 3 we show the coefficient of an instrumental variable regression of the score on the interaction of $\mathrm{B} \& \mathrm{E}$ and an indicator of Upperclass. Controls are female, dummies for mother's education, working mother, school type (private, public, voucher), education type (mixed, single-sex school, single-sex classroom), highschool GPA, college admission test scores (PSU) and university dummies. Standard errors, clustered at the university/major level, are presented in parentheses. ${ }^{* * *},{ }^{* *}$ and ${ }^{*}$ indicate statistical significance at the $99 \%, 95 \%$ and $90 \%$, respectively. 
Table 10: Gender Bias and Economics - Controlling for political ideology and religiosity

\begin{tabular}{|c|c|c|c|c|c|c|c|c|c|}
\hline \multirow{2}{*}{$\begin{array}{l}\text { Dependent variable: Score } \\
\text { Control: } \\
\text { Sample: }\end{array}$} & \multirow[b]{2}{*}{$\begin{array}{c}\text { All students } \\
(1)\end{array}$} & \multirow[b]{2}{*}{$\begin{array}{c}\text { Men } \\
(2) \\
\end{array}$} & \multirow[b]{2}{*}{$\begin{array}{c}\text { Women } \\
(3)\end{array}$} & \multicolumn{3}{|c|}{ Political ideology } & \multicolumn{3}{|c|}{ Religiosity } \\
\hline & & & & $\begin{array}{c}\text { All students } \\
\text { (4) }\end{array}$ & $\begin{array}{c}\text { Men } \\
(5)\end{array}$ & $\begin{array}{l}\text { Women } \\
(6)\end{array}$ & $\begin{array}{l}\text { All students } \\
(7)\end{array}$ & $\begin{array}{c}\text { Men } \\
(8)\end{array}$ & $\begin{array}{l}\text { Women } \\
(9)\end{array}$ \\
\hline $\mathrm{B} \& \mathrm{E}$ & $\begin{array}{c}0.106^{*} \\
(0.059)\end{array}$ & $\begin{array}{c}0.085 \\
(0.065)\end{array}$ & $\begin{array}{l}0.137^{*} \\
(0.079)\end{array}$ & $\begin{array}{c}-0.046 \\
(0.038)\end{array}$ & $\begin{array}{l}-0.053 \\
(0.041)\end{array}$ & $\begin{array}{l}-0.010 \\
(0.065)\end{array}$ & $\begin{array}{c}0.066 \\
(0.053)\end{array}$ & $\begin{array}{c}0.039 \\
(0.066)\end{array}$ & $\begin{array}{c}0.107 \\
(0.077)\end{array}$ \\
\hline Upperclass & $\begin{array}{c}-0.631 \\
(0.639)\end{array}$ & $\begin{array}{l}-1.521 \\
(0.962)\end{array}$ & $\begin{array}{l}-0.376 \\
(0.639)\end{array}$ & $\begin{array}{l}-0.263 \\
(0.577)\end{array}$ & $\begin{array}{l}-0.459 \\
(0.884)\end{array}$ & $\begin{array}{l}-0.351 \\
(0.585)\end{array}$ & $\begin{array}{l}-0.518 \\
(0.596)\end{array}$ & $\begin{array}{l}-1.095 \\
(0.825)\end{array}$ & $\begin{array}{l}-0.158 \\
(0.622)\end{array}$ \\
\hline DiD & $\begin{array}{c}0.092 \\
(0.080)\end{array}$ & $\begin{array}{c}0.183^{* *} \\
(0.074)\end{array}$ & $\begin{array}{c}0.035 \\
(0.121)\end{array}$ & $\begin{array}{c}0.078 \\
(0.068)\end{array}$ & $\begin{array}{c}0.127^{* *} \\
(0.062)\end{array}$ & $\begin{array}{c}0.040 \\
(0.124)\end{array}$ & $\begin{array}{c}0.089 \\
(0.092)\end{array}$ & $\begin{array}{l}0.169^{*} \\
(0.085)\end{array}$ & $\begin{array}{c}0.034 \\
(0.146)\end{array}$ \\
\hline Control & & & & $\begin{array}{c}0.185^{* * *} \\
(0.012)\end{array}$ & $\begin{array}{c}0.238^{* * *} \\
(0.021)\end{array}$ & $\begin{array}{c}0.136^{* * *} \\
(0.010)\end{array}$ & $\begin{array}{c}0.253^{* * * *} \\
(0.030)\end{array}$ & $\begin{array}{c}0.312^{* * *} \\
(0.052)\end{array}$ & $\begin{array}{c}0.205^{* * *} \\
(0.018)\end{array}$ \\
\hline Upperclass*Control & & & & $\begin{array}{c}0.016 \\
(0.011) \\
\end{array}$ & $\begin{array}{c}0.016 \\
(0.021) \\
\end{array}$ & $\begin{array}{c}0.017 \\
(0.016) \\
\end{array}$ & $\begin{array}{l}-0.003 \\
(0.039) \\
\end{array}$ & $\begin{array}{l}-0.005 \\
(0.071) \\
\end{array}$ & $\begin{array}{c}0.010 \\
(0.042) \\
\end{array}$ \\
\hline Observations & 3358 & 1651 & 1707 & 3288 & 1621 & 1667 & 3274 & 1613 & 1661 \\
\hline
\end{tabular}

Notes: First year includes students enrolled in first year in years 2017 and 2018, while Upperclass includes students enrolled in years 2 to 6 who were surveyed in 2017, 2018 and 2019. B\&E is an indicator for whether the student is enrolled in Business \& Economics and DiD is the difference-in-difference coefficient. In columns 1-3, Control corresponds to self-reported political ideology on a 0 to 10 scale, where 0 corresponds to the left, and 10 corresponds to the right. In columns 4-6, Control corresponds to religiosity, on a scale from 1 to 4 , where 1 indicates not religious and 4 indicates strongly religious. All columns include dummies for mother's education, working mother, school type (private, public, voucher), education type (mixed, single-sex school, single-sex classroom), highschool GPA, college admission test scores (PSU) and university dummies. Columns 1 and 4 also include controls for female students. Standard errors, clustered at the university/major level, are presented in parentheses. ${ }^{* * *},{ }^{* *}$ and $*$ indicate statistical significance at the $99 \%, 95 \%$ and $90 \%$, respectively. 
Table 11: Heterogeneous effects by the share of female students

\begin{tabular}{lccc}
\hline $\begin{array}{l}\text { Dependent variable: Score } \\
\text { Sample: }\end{array}$ & $\begin{array}{c}\text { All students } \\
(1)\end{array}$ & $\begin{array}{c}\text { Men } \\
(2)\end{array}$ & $\begin{array}{c}\text { Women } \\
(3)\end{array}$ \\
\hline B\&E & 0.081 & 0.104 & -0.140 \\
& $(0.330)$ & $(0.356)$ & $(0.427)$ \\
Upperclass & -0.633 & -1.973 & -0.219 \\
& $(0.808)$ & $(1.177)$ & $(0.858)$ \\
DiD & $0.671^{* *}$ & 0.358 & $1.057^{* * *}$ \\
& $(0.263)$ & $(0.375)$ & $(0.332)$ \\
B\&E*Share female students & 0.003 & -0.085 & 0.585 \\
& $(0.752)$ & $(0.798)$ & $(1.009)$ \\
DiD*Share female students & $-1.360^{* *}$ & -0.318 & $-2.451^{* * *}$ \\
& $(0.602)$ & $(0.929)$ & $(0.746)$ \\
Share female students & -0.568 & $-1.424^{* *}$ & 0.064 \\
& $(0.365)$ & $(0.556)$ & $(0.332)$ \\
Upperclass*Share female students & $-0.636^{*}$ & -0.178 & $-0.872^{* *}$ \\
& $(0.352)$ & $(0.557)$ & $(0.386)$ \\
\hline Observations & 2900 & 1453 & 1447 \\
\hline
\end{tabular}

Notes: First year includes students enrolled in first year in years 2017 and 2018, while Upperclass includes students enrolled in years 2 to 6 who were surveyed in 2017, 2018 and 2019. B\&E is an indicator for whether the student is enrolled in Business \& Economics and DiD is the difference-in-difference coefficient. All columns include dummies for mother's education, working mother, school type (private, public, voucher), education type (mixed, single-sex school, single-sex classroom), highschool GPA, college admission test scores (PSU) and university dummies. Column 1 also include controls for female students. Standard errors, clustered at the university/major level, are presented in parentheses. ***, ** and * indicate statistical significance at the $99 \%, 95 \%$ and $90 \%$, respectively. 
Table 12: Heterogeneous effects by the share of female professors

\begin{tabular}{|c|c|c|c|c|c|c|}
\hline \multirow{2}{*}{$\begin{array}{l}\text { Dependent Variable: Score } \\
\text { Sample: } \\
\text { Model: }\end{array}$} & \multicolumn{2}{|c|}{ All } & \multicolumn{2}{|c|}{ Men } & \multicolumn{2}{|c|}{ Women } \\
\hline & $\begin{array}{l}\text { DiD-FD } \\
\text { (1) }\end{array}$ & $\begin{array}{c}\text { Heckman } \\
\quad(2)\end{array}$ & $\begin{array}{c}\text { DiD-FD } \\
(3)\end{array}$ & $\begin{array}{c}\text { Heckman } \\
\text { (4) }\end{array}$ & $\begin{array}{c}\text { DiD-FD } \\
(5)\end{array}$ & $\begin{array}{c}\text { Heckman } \\
\quad(6)\end{array}$ \\
\hline less than $10 \%$ female professors & $\begin{array}{c}0.198 \\
(0.132)\end{array}$ & $\begin{array}{c}0.211^{* *} \\
(0.105)\end{array}$ & $\begin{array}{l}-0.020 \\
(0.275)\end{array}$ & $\begin{array}{c}-0.023 \\
(0.206)\end{array}$ & $\begin{array}{c}0.399^{* * *} \\
(0.124)\end{array}$ & $\begin{array}{c}0.428^{* * *} \\
(0.121)\end{array}$ \\
\hline between $10 \%$ and $30 \%$ female professors & $\begin{array}{l}0.133^{*} \\
(0.074)\end{array}$ & $\begin{array}{c}0.148^{* *} \\
(0.069)\end{array}$ & $\begin{array}{c}0.135^{* *} \\
(0.060)\end{array}$ & $\begin{array}{l}0.133^{*} \\
(0.070)\end{array}$ & $\begin{array}{c}0.137 \\
(0.143)\end{array}$ & $\begin{array}{c}0.173 \\
(0.124)\end{array}$ \\
\hline more than $30 \%$ female professors & $\begin{array}{l}-0.103 \\
(0.063)\end{array}$ & $\begin{array}{l}-0.054 \\
(0.053)\end{array}$ & $\begin{array}{c}0.110 \\
(0.092)\end{array}$ & $\begin{array}{c}0.152 \\
(0.100)\end{array}$ & $\begin{array}{l}-0.314 \\
(0.206)\end{array}$ & $\begin{array}{l}-0.260 \\
(0.228)\end{array}$ \\
\hline Observations & 283 & 873 & 123 & 441 & 160 & 422 \\
\hline $\begin{array}{l}\text { Controls } \\
\text { Student FE }\end{array}$ & $\begin{array}{l}\text { no } \\
\text { yes }\end{array}$ & $\begin{array}{c}\text { no } \\
\text { yes }\end{array}$ & $\begin{array}{l}\text { no } \\
\text { yes }\end{array}$ & $\begin{array}{l}\text { no } \\
\text { yes }\end{array}$ & $\begin{array}{l}\text { no } \\
\text { yes }\end{array}$ & $\begin{array}{l}\text { no } \\
\text { yes }\end{array}$ \\
\hline
\end{tabular}

Notes: Each column presents the difference-in-difference coefficient interacted with an indicator variable that takes the value of 1 if students had less than $10 \%$ female professors, an indicator variable that takes the value of 1 if students had between $10 \%$ and $30 \%$ female professors, and an indicator variable that takes the value of 1 if students had more than $30 \%$ female professors. All columns are estimated in first differences. In columns 5, 7 and 9, we use a heckman selection model to correct for attrition bias in the model with student fixed effect. Variables included in the selection model are a dummy for whether the student is enrolled in Business \& Economics (B\&E), the score in either wave 0 or 3, and a dummy for whether the student gave their contact phone in addition to their contact email. Standard errors, clustered at the student level, are presented in parentheses. ${ }^{* * *},{ }^{* *}$ and ${ }^{*}$ indicate statistical significance at the $99 \%$, $95 \%$ and $90 \%$, respectively. 


\section{Appendix}

\section{Survey Questions}

- Hostile Sexism: simple average of answer to following questions: (6 point scale, from strongly disagree to strongly agree)

1. Women are easily offended.

2. Women try to gain power by controlling men.

3. Women exaggerate the problems they have at work.

4. Once a woman gets a man to commit to her, she usually tries to control him tightly.

5. When women are beaten or outperformed by men in a fair competition, they generally argue they have been discriminated against.

- Benevolent Sexism: simple average of answer to following questions: (6 point scale, from strongly disagree to strongly agree)

1. Even when a man accomplishes many goals in his life, he can never feel truly complete unless he has the love of a woman.

2. People cannot be truly happy in their lives unless they have a partner of the opposite gender.

3. Every man must have a woman to love.

4. Men are incomplete without a woman.

5. Men should be willing to sacrifice their own well-being in order to provide economic stability to women.

- Gender Roles: Traditional. Simple average of responses to following questions (5 point scale, from strongly agree to strongly disagree; reversed if appropriate)

1. A working mother can establish a relationship as warm and solid with their children as a non-working mother.

2. A preschool kid is likely to suffer if his or her mother works. 
3. Overall, after considering everything good and bad, family life is likely to be negatively affected if the female works full time.

4. Most women are not interested in having important jobs

5. Most women are happier staying at home to take care of their children

6. It is more important for a woman to help her husband than having a career

7. When it comes to getting a job, men should be prioritized over women for most jobs because they have the responsibility of generating an income for their families

8. Both men and women must contribute to generating income for the family

9. Men's job is to make money, whereas women's responsibility is to take care of the domestic work and the family.

- Gender Roles: Proactive. Simple average of responses to following questions (5 point scale, from strongly agree to strongly disagree)

1. Men should assume a greater degree of responsibility in domestic work than they currently do.

2. Men should assume a greater degree of responsibility in the care of their children than they currently do

3. Young men should be incentivized to take jobs that are usually done by women (nurses, secretaries, etc.)

4. School counselors should incentivize women to prepare for jobs that are now usually done by men.

5. Schools teach women to aim for less important jobs.

- Gender Differences in Math. Simple average of responses to following questions (5 point scale, from strongly agree to strongly disagree)

1. It is possible that men are currently more skilled in maths than women.

2. In general, men are better than women in maths. 
- Gender Pay Gap Due to Skills and Preferences. Respondents asked to evaluate how important differences in skills/preferences are for explaining gender gap. Simple average of responses to following questions ( 5 point scale, from strongly agree to strongly disagree, reversed if appropriate)

1. Women tend to work in low-wage occupations, in order to have more time to spend on other activities.

2. On average, women tend to be less productive than men in the same task or job.

3. Women earn lower wages because, on average, they have accumulated fewer years of schooling and work experience.

4. Women do not like to compete for jobs or promotions.

5. Women prefer jobs with low but safe wages than jobs with higher but more uncertain wages.

6. Women prefer not to work in high-paying jobs because they fear that it will be hard for them to find and keep a stable relationship.

7. Women accept the first wage they are being offered, whereas men tend to negotiate their wages.

- Gender Pay Gap Due to Discrimination. Simple average of responses to following questions ( 5 point scale, from strongly agree to strongly disagree, reversed if appropriate)

1. Many qualified women cannot get good jobs; for men with the same qualifications it is easier to get them.

2. How important are the following factors in explaining the gender pay gap? [list of factors] On average, either consciously or not, men are favored in negotiations for new jobs or promotions. 
Additional Tables 
Table A-1: Sample vs. enrolled students

\begin{tabular}{|c|c|c|c|c|c|c|c|c|c|c|c|c|}
\hline & \multicolumn{4}{|c|}{ All Students } & \multicolumn{4}{|c|}{ B\&E Students } & \multicolumn{4}{|c|}{ Students in Other Disciplines } \\
\hline & $\begin{array}{l}\text { Enrolled } \\
\text { (1) }\end{array}$ & $\begin{array}{l}\text { Sample } \\
(2)\end{array}$ & $\begin{array}{l}\text { Diff. } \\
(3)\end{array}$ & $\begin{array}{l}\text { Diff. } \\
(4)\end{array}$ & $\begin{array}{l}\text { Enrolled } \\
(5)\end{array}$ & $\begin{array}{l}\text { Sample } \\
(6)\end{array}$ & $\begin{array}{l}\text { Diff. } \\
(7)\end{array}$ & $\begin{array}{l}\text { Diff. } \\
(8)\end{array}$ & $\begin{array}{l}\text { Enrolled } \\
\quad(9)\end{array}$ & $\begin{array}{l}\text { Sample } \\
(10)\end{array}$ & $\begin{array}{l}\text { Diff. } \\
(11)\end{array}$ & $\begin{array}{l}\text { Diff. } \\
(12)\end{array}$ \\
\hline \multirow[t]{2}{*}{ Pecentage female } & 0.414 & 0.505 & $\begin{array}{c}0.091 * * * \\
(0.010)\end{array}$ & $\begin{array}{c}0.090^{* * *} \\
(0.010)\end{array}$ & 0.439 & 0.477 & $\begin{array}{l}0.038^{* *} \\
(0.019)\end{array}$ & $\begin{array}{c}0.058^{* * *} \\
(0.019)\end{array}$ & 0.405 & 0.515 & $\begin{array}{c}0.111^{* * * *} \\
(0.012)\end{array}$ & $\begin{array}{c}0.106^{* * * *} \\
(0.011)\end{array}$ \\
\hline & {$[40,166]$} & {$[2,632]$} & {$[42,798]$} & {$[42,798]$} & {$[10,421]$} & {$[708]$} & {$[11,129]$} & {$[11,129]$} & {$[29,745]$} & {$[1,924]$} & {$[31,669]$} & {$[31,669]$} \\
\hline \multirow[t]{2}{*}{$\begin{array}{l}\text { Mother studied college } \\
\text { or more }\end{array}$} & & 0.566 & $\begin{array}{c}0.052^{* * *} \\
(0.011)\end{array}$ & $\begin{array}{l}0.008 \\
(0.010)\end{array}$ & & 0.623 & $\begin{array}{c}0.063^{* * *} \\
(0.020)\end{array}$ & $\begin{array}{l}-0.031^{*} \\
(0.018)\end{array}$ & 0.499 & 0.546 & $\begin{array}{c}0.047^{* * *} \\
(0.012)\end{array}$ & $\begin{array}{l}0.015 \\
(0.012)\end{array}$ \\
\hline & {$[36,323]$} & {$[2,377]$} & {$[38,700]$} & {$[38,700]$} & {$[9,261]$} & {$[626]$} & {$[9,887]$} & {$[9,887]$} & {$[27,062]$} & {$[1,751]$} & {$[28,813]$} & {$[28,813]$} \\
\hline \multirow{2}{*}{$\begin{array}{l}\text { Father studied college } \\
\text { or more }\end{array}$} & 0.559 & 0.627 & $0.068^{* * *}$ & $0.024^{* *}$ & 0.610 & 0.688 & $0.078^{* * *}$ & -0.006 & 0.542 & 0.604 & $0.063^{* * *}$ & $0.029^{* *}$ \\
\hline & {$[32,621]$} & {$[2,145]$} & & & {$[8,465]$} & {$[583]$} & & & {$[24,156]$} & {$[1,562]$} & & \\
\hline \multirow[t]{2}{*}{ Working mother } & & 0.539 & $\begin{array}{c}0.040^{* * *} \\
(0.013)\end{array}$ & $\begin{array}{l}0.025^{*} \\
(0.013)\end{array}$ & 0.497 & 0.550 & $\begin{array}{l}0.053^{* *} \\
(0.025)\end{array}$ & $\begin{array}{l}0.023 \\
(0.025)\end{array}$ & 0.500 & 0.535 & $\begin{array}{l}0.035^{* *} \\
(0.015)\end{array}$ & $\begin{array}{l}0.024 \\
(0.015)\end{array}$ \\
\hline & {$[27,580]$} & {$[1,610]$} & {$[29,190]$} & {$[29,190]$} & {$[7,388]$} & {$[431]$} & {$[7,819]$} & {$[7,819]$} & {$[20,192]$} & {$[1,179]$} & {$[21,371]$} & {$[21,371]$} \\
\hline \multirow[t]{2}{*}{ Public school } & 0.243 & 0.251 & $\begin{array}{l}0.007 \\
(0.009)\end{array}$ & $\begin{array}{l}0.016^{*} \\
(0.009)\end{array}$ & 0.187 & 0.187 & $\begin{array}{l}0.000 \\
(0.015)\end{array}$ & $\begin{array}{c}0.039^{* * *} \\
(0.015)\end{array}$ & 0.263 & 0.274 & $\begin{array}{l}0.011 \\
(0.010)\end{array}$ & $\begin{array}{c}0.014 \\
(0.010)\end{array}$ \\
\hline & {$[40,166]$} & {$[2,598]$} & {$[42,764]$} & {$[42,764]$} & {$[10,421]$} & [694] & {$[11,115]$} & {$[11,115]$} & {$[29,745]$} & {$[1,904]$} & {$[31,649]$} & {$[31,649]$} \\
\hline \multirow[t]{2}{*}{ Voucher school } & & 0.413 & $\begin{array}{c}-0.043^{* * *} \\
(0.010)\end{array}$ & $\begin{array}{l}-0.013 \\
(0.010)\end{array}$ & 0.392 & 0.334 & $\begin{array}{c}-0.058^{* * *} \\
(0.019)\end{array}$ & $\begin{array}{c}0.015 \\
(0.018)\end{array}$ & 0.478 & 0.441 & $\begin{array}{c}-0.037^{* * *} \\
(0.012)\end{array}$ & $\begin{array}{l}-0.013 \\
(0.012)\end{array}$ \\
\hline & {$[40$} & {$[2,598]$} & {$[42,764]$} & {$[42,764]$} & {$[10,421]$} & [694] & {$[11,115]$} & {$[11,115]$} & {$[29,745]$} & {$[1,904]$} & {$[31,649]$} & {$[31,649]$} \\
\hline \multirow[t]{2}{*}{ Private school } & 0.281 & 0.334 & $\begin{array}{c}0.053^{* * *} \\
(0.009)\end{array}$ & $\begin{array}{l}0.011 \\
(0.008)\end{array}$ & 0.401 & 0.474 & $\begin{array}{c}0.073^{* * *} \\
(0.019)\end{array}$ & $\begin{array}{c}-0.043^{* * *} \\
(0.015)\end{array}$ & 0.239 & 0.283 & $\begin{array}{c}0.044^{* * *} \\
(0.010)\end{array}$ & $\begin{array}{l}0.014 \\
(0.010)\end{array}$ \\
\hline & {$[40,166]$} & {$[2,598]$} & {$[42,764]$} & {$[42,764]$} & {$[10,421]$} & [694] & {$[11,115]$} & {$[11,115]$} & {$[29,745]$} & {$[1,904]$} & {$[31,649]$} & {$[31,649]$} \\
\hline \multirow[t]{2}{*}{ PSU math } & 659.17 & 680.13 & $\begin{array}{c}20.96^{* * *} \\
(1.580)\end{array}$ & $\begin{array}{l}7.38^{* * *} \\
(1.259)\end{array}$ & 662.52 & 694.61 & $\begin{array}{c}32.09^{* * *} \\
(3.047)\end{array}$ & $\begin{array}{c}3.11^{*} \\
(1.836)\end{array}$ & 657.99 & 674.80 & $\begin{array}{c}16.81^{* * *} \\
(1.846)\end{array}$ & $\begin{array}{l}7.18^{* * *} \\
(1.524)\end{array}$ \\
\hline & {$[40,166]$} & {$[2,632]$} & {$[42,798]$} & {$[42,798]$} & {$[10,421]$} & {$[708]$} & {$[11,129]$} & {$[11,129]$} & {$[29,745]$} & & {$[31,669]$} & {$[31,669]$} \\
\hline \multirow[t]{2}{*}{ High school gpa } & 665.00 & 682.50 & $\begin{array}{c}17.50^{* * *} \\
(1.537)\end{array}$ & $\begin{array}{c}6.45^{* * *} \\
(1.273)\end{array}$ & 662.21 & 684.59 & $\begin{array}{c}22.38^{* * * *} \\
(3.046)\end{array}$ & $\begin{array}{l}-0.93 \\
(2.143)\end{array}$ & 665.98 & 681.72 & $\begin{array}{c}15.75^{* * *} \\
(1.779)\end{array}$ & $\begin{array}{c}8.42^{* * *} \\
(1.531)\end{array}$ \\
\hline & {$[40,166]$} & {$[2,632]$} & {$[42,798]$} & {$[42,798]$} & {$[10,421]$} & [708] & {$[11,129]$} & {$[11,129]$} & {$[29,745]$} & {$[1,924]$} & {$[31,669]$} & {$[31,669]$} \\
\hline
\end{tabular}

Notes: Column 1 includes all students enrolled in university-major pairs contacted for this study, including students who answered the survey. Column 2 includes students who answered our survey. Columns 3 and 4 show the difference between the previous columns. Columns 5-8 shows all students enrolled in Business and Economics contacted for this study, students in Business and Economics who answered our survey and the difference between the previous samples. Columns 9-12 shows all students enrolled in majors other than B\&E contacted for this study, students in majors other than B\&E who answered our survey and the difference between the previous samples. Standard errors are presented in parentheses. Square brackets indicate the number of observations. ${ }^{* *},{ }^{* *}$ and $*$ indicate statistical significance at the $99 \%$, $95 \%$ and $90 \%$, respectively. 
Table A-2: Descriptive Statistics - Dependent Variables by Wave

\begin{tabular}{|c|c|c|c|c|c|c|}
\hline & \multicolumn{5}{|c|}{ Sample of students } & \multirow{3}{*}{$\begin{array}{c}\text { Difference between samples } \\
\text { First year } \\
\text { vs Upperclass } \\
(6)\end{array}$} \\
\hline & \multicolumn{2}{|c|}{ First year } & \multicolumn{3}{|c|}{ Upperclass } & \\
\hline & $\begin{array}{c}2017 \\
(1)\end{array}$ & $\begin{array}{c}2018 \\
(2)\end{array}$ & $\begin{array}{c}2017 \\
(3)\end{array}$ & $\begin{array}{c}2018 \\
(4)\end{array}$ & $\begin{array}{c}2019 \\
(5)\end{array}$ & \\
\hline \multirow[t]{3}{*}{ Gender and Science IAT } & 0.033 & -0.065 & 0.028 & -0.083 & -0.060 & 0.023 \\
\hline & $(0.998)$ & $(1.055)$ & $(0.994)$ & $(0.985)$ & $(0.908)$ & $(0.047)$ \\
\hline & {$[448]$} & {$[421]$} & {$[718]$} & {$[21]$} & {$[177]$} & {$[1,785]$} \\
\hline \multirow[t]{3}{*}{ Gender and Career IAT } & 0.125 & -0.024 & -0.069 & -0.244 & 0.025 & $-0.112^{* *}$ \\
\hline & $(0.967)$ & $(1.025)$ & $(1.014)$ & $(0.945)$ & $(0.952)$ & $(0.046)$ \\
\hline & {$[490]$} & [413] & {$[796]$} & [13] & {$[167]$} & {$[1,879]$} \\
\hline \multirow[t]{3}{*}{ Hostile Sexism } & 0.230 & -0.001 & -0.013 & -0.378 & -0.468 & $-0.219 * * *$ \\
\hline & $(0.967)$ & $(0.992)$ & $(1.024)$ & $(0.899)$ & $(0.808)$ & $(0.034)$ \\
\hline & {$[858]$} & {$[782]$} & {$[1,515]$} & {$[32]$} & [333] & {$[3,520]$} \\
\hline \multirow[t]{3}{*}{ Benevolent Sexims } & 0.223 & 0.018 & -0.053 & -0.188 & -0.343 & $-0.232^{* * *}$ \\
\hline & $(1.051)$ & $(1.018)$ & $(0.970)$ & $(1.013)$ & $(0.819)$ & $(0.034)$ \\
\hline & {$[859]$} & {$[782]$} & {$[1,516]$} & {$[32]$} & [333] & {$[3,522]$} \\
\hline \multirow[t]{3}{*}{ Gender roles, traditional } & 0.213 & 0.028 & -0.088 & -0.172 & -0.223 & $-0.240 * * *$ \\
\hline & $(1.012)$ & $(1.016)$ & $(0.980)$ & $(0.839)$ & $(0.926)$ & $(0.033)$ \\
\hline & [931] & [837] & {$[1,528]$} & [34] & [344] & {$[3,674]$} \\
\hline \multirow[t]{3}{*}{ Gender Roles Proactive } & 0.283 & 0.055 & -0.126 & 0.129 & -0.338 & $-0.335^{* * *}$ \\
\hline & $(0.924)$ & $(0.992)$ & $(1.004)$ & $(1.248)$ & $(0.979)$ & $(0.033)$ \\
\hline & [930] & {$[836]$} & {$[1,528]$} & {$[34]$} & {$[344]$} & {$[3,672]$} \\
\hline \multirow[t]{3}{*}{ Gender differences in math } & 0.066 & -0.109 & 0.089 & 0.031 & -0.295 & 0.035 \\
\hline & $(0.982)$ & $(0.964)$ & $(1.041)$ & $(0.939)$ & $(0.886)$ & $(0.033)$ \\
\hline & {$[930]$} & [834] & {$[1,513]$} & {$[34]$} & {$[344]$} & {$[3,655]$} \\
\hline \multirow[t]{3}{*}{ Gender pay gap due to discrimination } & 0.076 & 0.044 & -0.016 & -0.156 & -0.219 & $-0.116 * * *$ \\
\hline & $(0.979)$ & $(1.013)$ & $(1.006)$ & $(0.872)$ & $(0.980)$ & $(0.033)$ \\
\hline & [927] & [826] & {$[1,528]$} & {$[33]$} & {$[344]$} & {$[3,658]$} \\
\hline \multirow[t]{3}{*}{ Gender pay gap due to skills and preferences } & 0.112 & -0.036 & -0.049 & -0.108 & 0.007 & $-0.082^{* *}$ \\
\hline & $(0.998)$ & $(1.059)$ & $(0.962)$ & $(0.940)$ & $(1.026)$ & $(0.034)$ \\
\hline & {$[878]$} & {$[785]$} & {$[1,510]$} & {$[32]$} & {$[340]$} & {$[3,545]$} \\
\hline \multirow[t]{3}{*}{ Score } & 0.261 & 0.018 & -0.058 & -0.122 & -0.421 & $-0.271^{* * *}$ \\
\hline & $(0.959)$ & $(0.991)$ & (1.006) & $(1.050)$ & $(0.913)$ & $(0.034)$ \\
\hline & {$[842]$} & {$[750]$} & {$[1,475]$} & {$[31]$} & [330] & {$[3,428]$} \\
\hline
\end{tabular}

Notes: First year students includes students enrolled in first year in years 2017 and 2018, while Upperclass includes students enrolled in years 2 to 6 who were surveyed in 2017, 2018 and 2019. Columns 1-5 show the mean, standard deviation (in parentheses) and number of observations (in square brackets) of each dependent variable. Column 6 shows the differences between samples, standard error (in parenthesis) and number of observations (in square brackets). ${ }^{* * *},{ }^{* *}$ and $*$ indicate statistical significance at the $99 \%, 95 \%$ and $90 \%$, respectively. 
Table A-3: Descriptive Statistics - Control Variables by Wave

\begin{tabular}{|c|c|c|c|c|c|c|}
\hline & \multicolumn{5}{|c|}{ Sample of students } & \multirow{3}{*}{$\begin{array}{c}\text { Difference between samples } \\
\text { First year } \\
\text { vs Upperclass } \\
(6)\end{array}$} \\
\hline & \multicolumn{2}{|c|}{ First year } & \multicolumn{3}{|c|}{ Upperclass } & \\
\hline & $\begin{array}{c}2017 \\
(1)\end{array}$ & $\begin{array}{c}2018 \\
(2)\end{array}$ & $\begin{array}{c}2017 \\
(3)\end{array}$ & $\begin{array}{c}2018 \\
(4)\end{array}$ & $\begin{array}{c}2019 \\
(5)\end{array}$ & \\
\hline \multirow[t]{3}{*}{ Academic year } & 1.000 & 1.000 & 3.636 & 2.000 & 2.000 & $2.311^{* * *}$ \\
\hline & $(0.000)$ & $(0.000)$ & $(1.329)$ & $(0.000)$ & $(0.000)$ & $(0.032)$ \\
\hline & {$[965]$} & {$[851]$} & {$[1,528]$} & {$[34]$} & {$[345]$} & {$[3,723]$} \\
\hline \multirow[t]{3}{*}{ Percentage female } & 0.505 & 0.498 & 0.505 & 0.471 & 0.554 & 0.011 \\
\hline & $(0.500)$ & $(0.500)$ & $(0.500)$ & $(0.507)$ & $(0.498)$ & $(0.017)$ \\
\hline & {$[925]$} & [831] & {$[1,525]$} & {$[34]$} & {$[341]$} & {$[3,656]$} \\
\hline \multirow[t]{3}{*}{ Mother education } & 13.932 & 13.715 & 14.122 & 13.882 & 13.472 & 0.171 \\
\hline & $(3.224)$ & $(3.221)$ & $(3.105)$ & $(3.102)$ & $(3.405)$ & $(0.106)$ \\
\hline & {$[915]$} & {$[821]$} & {$[1,520]$} & {$[34]$} & {$[343]$} & {$[3,633]$} \\
\hline \multirow[t]{3}{*}{ Working mother } & 0.756 & 0.779 & 0.775 & 0.742 & 0.782 & 0.008 \\
\hline & $(0.430)$ & $(0.415)$ & $(0.418)$ & $(0.445)$ & $(0.413)$ & $(0.015)$ \\
\hline & {$[721]$} & {$[743]$} & {$[1,500]$} & {$[31]$} & [340] & {$[3,335]$} \\
\hline \multirow[t]{3}{*}{ Single sex school } & 0.172 & 0.187 & 0.239 & 0.353 & 0.215 & $0.057 * * *$ \\
\hline & $(0.378)$ & $(0.390)$ & $(0.426)$ & $(0.485)$ & $(0.411)$ & $(0.013)$ \\
\hline & {$[923]$} & [829] & {$[1,522]$} & {$[34]$} & {$[321]$} & {$[3,629]$} \\
\hline \multirow[t]{3}{*}{ Single sex classroom } & 0.012 & 0.001 & 0.005 & 0.029 & 0.000 & -0.003 \\
\hline & $(0.109)$ & $(0.035)$ & $(0.068)$ & $(0.171)$ & $(0.000)$ & $(0.002)$ \\
\hline & {$[923]$} & [829] & {$[1,522]$} & {$[34]$} & {$[321]$} & {$[3,629]$} \\
\hline \multirow[t]{3}{*}{ Coeducational school } & 0.820 & 0.814 & 0.762 & 0.618 & 0.791 & $-0.053^{* * *}$ \\
\hline & $(0.384)$ & $(0.389)$ & $(0.426)$ & $(0.493)$ & $(0.407)$ & $(0.014)$ \\
\hline & [923] & {$[829]$} & {$[1,522]$} & {$[34]$} & {$[321]$} & {$[3,629]$} \\
\hline \multirow[t]{3}{*}{ Public school } & 0.240 & 0.295 & 0.256 & 0.235 & 0.357 & 0.007 \\
\hline & $(0.427)$ & $(0.456)$ & $(0.437)$ & $(0.431)$ & $(0.480)$ & $(0.015)$ \\
\hline & {$[920]$} & {$[834]$} & {$[1,524]$} & {$[34]$} & {$[322]$} & {$[3,634]$} \\
\hline \multirow[t]{3}{*}{ Voucher school } & 0.405 & 0.438 & 0.404 & 0.294 & 0.373 & -0.024 \\
\hline & $(0.491)$ & $(0.496)$ & $(0.491)$ & $(0.462)$ & $(0.484)$ & $(0.016)$ \\
\hline & {$[920]$} & {$[834]$} & {$[1,524]$} & {$[34]$} & {$[322]$} & {$[3,634]$} \\
\hline \multirow[t]{3}{*}{ Private school } & 0.362 & 0.285 & 0.350 & 0.471 & 0.276 & 0.014 \\
\hline & $(0.481)$ & $(0.452)$ & $(0.477)$ & $(0.507)$ & $(0.448)$ & $(0.016)$ \\
\hline & [920] & [834] & {$[1,524]$} & {$[34]$} & [322] & {$[3,634]$} \\
\hline \multirow[t]{3}{*}{ PSU math } & 674.900 & 662.046 & 685.328 & 716.647 & 671.612 & $14.984^{* * *}$ \\
\hline & $(74.111)$ & $(77.075)$ & $(77.324)$ & $(49.735)$ & $(79.506)$ & $(2.746)$ \\
\hline & {$[733]$} & {$[736]$} & {$[1,329]$} & {$[34]$} & [307] & {$[3,139]$} \\
\hline \multirow[t]{3}{*}{ High school gpa } & 679.450 & 670.590 & 682.052 & 695.294 & 678.296 & $6.620 * *$ \\
\hline & $(70.555)$ & $(75.398)$ & $(71.506)$ & $(49.095)$ & $(74.612)$ & $(2.589)$ \\
\hline & [733] & {$[736]$} & {$[1,329]$} & {$[34]$} & [307] & {$[3,139]$} \\
\hline
\end{tabular}

Notes: First year students includes students enrolled in first year in years 2017 and 2018, while Upperclass includes students enrolled in years 2 to 6 who were surveyed in 2017, 2018 and 2019. Columns 1-5 show the mean, standard deviation (in parentheses) and number of observations (in square brackets) of each control variable. Column 6 shows the differences between samples, standard error (in parenthesis) and number of observations (in square brackets). ${ }^{* * *},{ }^{* *}$ and ${ }^{*}$ indicate statistical significance at the $99 \%, 95 \%$ and $90 \%$, respectively. 
Table A-4: Testing for Selective Attrition

\begin{tabular}{lc}
\hline Dependent Variable: & Prob Follow-up \\
& \\
\hline Economics & $-0.091^{* *}$ \\
& $(0.037)$ \\
Score & $-0.072^{* *}$ \\
& $(0.033)$ \\
Economics $\times$ Score & 0.008 \\
& $(0.035)$ \\
Constant & $0.370^{* *}$ \\
& $(0.034)$ \\
\hline Observations & 893 \\
\hline
\end{tabular}

Notes: The sample includes students enrolled in first year in 2017 and 2018 that were surveyed in waves 0 and 3 . The dependent variable is the probability of observing student $i$ in the follow-up survey (waves 4 or 5). Standard errors, clustered at the university/major level, are presented in parentheses. $* * *, * *$ and * indicate statistical significance at the $99 \%, 95 \%$ and $90 \%$, respectively. 
Table A-5: Are economic students more sexist than other students? - All controls

\begin{tabular}{|c|c|c|c|c|c|c|}
\hline Sample: & $\begin{array}{c}\text { All students } \\
\text { (1) }\end{array}$ & $\begin{array}{l}\text { Male } \\
(2)\end{array}$ & $\begin{array}{c}\text { Female } \\
(3)\end{array}$ & $\begin{array}{c}\text { All students } \\
(4)\end{array}$ & $\begin{array}{c}\text { Male } \\
(5)\end{array}$ & $\begin{array}{c}\text { Female } \\
(6)\end{array}$ \\
\hline $\mathrm{B} \& \mathrm{E}$ & $\begin{array}{c}0.144^{* *} \\
(0.063)\end{array}$ & $\begin{array}{c}0.169^{* *} \\
(0.070)\end{array}$ & $\begin{array}{c}0.145^{* *} \\
(0.071)\end{array}$ & $\begin{array}{l}0.106^{*} \\
(0.059)\end{array}$ & $\begin{array}{c}0.085 \\
(0.065)\end{array}$ & $\begin{array}{l}0.137^{*} \\
(0.079)\end{array}$ \\
\hline Female student & $\begin{array}{c}-0.667^{* * *} \\
(0.040)\end{array}$ & & & $\begin{array}{c}-0.643^{* * *} \\
(0.046)\end{array}$ & & \\
\hline Mother education & $\begin{array}{l}-0.011^{*} \\
(0.006)\end{array}$ & $\begin{array}{l}-0.003 \\
(0.011)\end{array}$ & $\begin{array}{c}-0.020^{* * *} \\
(0.007)\end{array}$ & $\begin{array}{c}-0.018^{* *} \\
(0.008)\end{array}$ & $\begin{array}{l}-0.006 \\
(0.014)\end{array}$ & $\begin{array}{c}-0.033^{* * *} \\
(0.009)\end{array}$ \\
\hline Working mother & $\begin{array}{c}-0.259^{* * *} \\
(0.030)\end{array}$ & $\begin{array}{c}-0.304^{* * *} \\
(0.051)\end{array}$ & $\begin{array}{c}-0.209^{* * *} \\
(0.053)\end{array}$ & $\begin{array}{c}-0.248^{* * *} \\
(0.045)\end{array}$ & $\begin{array}{c}-0.281^{\text {*** }} \\
(0.091)\end{array}$ & $\begin{array}{c}-0.200^{* *} \\
(0.078)\end{array}$ \\
\hline Working mother status missing & $\begin{array}{c}0.161^{* *} \\
(0.074)\end{array}$ & $\begin{array}{l}0.152^{*} \\
(0.084)\end{array}$ & $\begin{array}{c}0.141 \\
(0.108)\end{array}$ & $\begin{array}{c}0.073 \\
(0.066)\end{array}$ & $\begin{array}{c}0.026 \\
(0.112)\end{array}$ & $\begin{array}{c}0.072 \\
(0.106)\end{array}$ \\
\hline Private school & $\begin{array}{c}0.125 \\
(0.104)\end{array}$ & $\begin{array}{c}0.152 \\
(0.130)\end{array}$ & $\begin{array}{c}0.084 \\
(0.095)\end{array}$ & $\begin{array}{l}0.174 \\
(0.153)\end{array}$ & $\begin{array}{c}0.273 \\
(0.182)\end{array}$ & $\begin{array}{c}0.058 \\
(0.154)\end{array}$ \\
\hline Voucher school & $\begin{array}{c}0.049 \\
(0.048)\end{array}$ & $\begin{array}{c}0.042 \\
(0.081)\end{array}$ & $\begin{array}{c}0.064 \\
(0.043)\end{array}$ & $\begin{array}{l}0.075 \\
(0.060)\end{array}$ & $\begin{array}{c}0.081 \\
(0.097)\end{array}$ & $\begin{array}{c}0.064 \\
(0.071)\end{array}$ \\
\hline Only-boys school & $\begin{array}{l}-0.219 \\
(0.219)\end{array}$ & $\begin{array}{l}-0.225 \\
(0.363)\end{array}$ & $\begin{array}{c}0.249 \\
(0.620)\end{array}$ & $\begin{array}{l}0.025 \\
(0.261)\end{array}$ & $\begin{array}{c}0.131 \\
(0.642)\end{array}$ & $\begin{array}{c}0.951^{* * *} \\
(0.250)\end{array}$ \\
\hline Only-girls school & $\begin{array}{l}-0.187 \\
(0.207)\end{array}$ & $\begin{array}{l}-0.704 \\
(0.520)\end{array}$ & $\begin{array}{l}-0.204 \\
(0.137)\end{array}$ & $\begin{array}{l}-0.023 \\
(0.248)\end{array}$ & $\begin{array}{l}-0.699 \\
(0.898)\end{array}$ & $\begin{array}{l}-0.137 \\
(0.164)\end{array}$ \\
\hline Coeducational school & $\begin{array}{l}-0.185 \\
(0.220)\end{array}$ & $\begin{array}{l}-0.190 \\
(0.366)\end{array}$ & $\begin{array}{l}-0.200 \\
(0.145)\end{array}$ & $\begin{array}{l}-0.027 \\
(0.276)\end{array}$ & $\begin{array}{l}0.078 \\
(0.677)\end{array}$ & $\begin{array}{l}-0.152 \\
(0.166)\end{array}$ \\
\hline PSU math & $\begin{array}{l}-0.000 \\
(0.001)\end{array}$ & $\begin{array}{l}-0.000 \\
(0.001)\end{array}$ & $\begin{array}{l}-0.000 \\
(0.000)\end{array}$ & $\begin{array}{l}-0.001 \\
(0.001)\end{array}$ & $\begin{array}{l}-0.001 \\
(0.001)\end{array}$ & $\begin{array}{l}-0.000 \\
(0.001)\end{array}$ \\
\hline High school GPA & $\begin{array}{l}-0.000 \\
(0.000)\end{array}$ & $\begin{array}{l}-0.001 \\
(0.001)\end{array}$ & $\begin{array}{l}-0.000 \\
(0.000)\end{array}$ & $\begin{array}{l}-0.000 \\
(0.001)\end{array}$ & $\begin{array}{l}-0.001 \\
(0.001)\end{array}$ & $\begin{array}{c}0.000 \\
(0.001)\end{array}$ \\
\hline B\&E $\times$ Upperclass & & & & $\begin{array}{c}0.092 \\
(0.080)\end{array}$ & $\begin{array}{c}0.183^{* *} \\
(0.074)\end{array}$ & $\begin{array}{c}0.035 \\
(0.121)\end{array}$ \\
\hline Upperclass students & & & & $\begin{array}{l}-0.631 \\
(0.639)\end{array}$ & $\begin{array}{l}-1.521 \\
(0.962)\end{array}$ & $\begin{array}{l}-0.376 \\
(0.639)\end{array}$ \\
\hline Missing PSU and High school GPA & & & & $\begin{array}{l}-0.363 \\
(0.526)\end{array}$ & $\begin{array}{l}-0.899 \\
(0.756)\end{array}$ & $\begin{array}{c}0.210 \\
(0.492)\end{array}$ \\
\hline Upperclass $\times$ Working mother & & & & $\begin{array}{c}-0.021 \\
(0.065)\end{array}$ & $\begin{array}{l}-0.037 \\
(0.126)\end{array}$ & $\begin{array}{c}-0.026 \\
(0.108)\end{array}$ \\
\hline Upperclass $\times$ Working mother status missing & & & & $\begin{array}{c}-0.314^{* *} \\
(0.133)\end{array}$ & $\begin{array}{l}-0.055 \\
(0.262)\end{array}$ & $\begin{array}{c}-0.483^{* * *} \\
(0.170)\end{array}$ \\
\hline Upperclass $\times$ Mother education & & & & $\begin{array}{l}0.015^{*} \\
(0.009)\end{array}$ & $\begin{array}{c}0.003 \\
(0.016)\end{array}$ & $\begin{array}{c}0.029^{* *} \\
(0.012)\end{array}$ \\
\hline Upperclass $\times$ Private school & & & & $\begin{array}{l}-0.104 \\
(0.117)\end{array}$ & $\begin{array}{l}-0.208 \\
(0.176)\end{array}$ & $\begin{array}{c}0.025 \\
(0.144)\end{array}$ \\
\hline Upperclass $\times$ Voucher school & & & & $\begin{array}{l}-0.060 \\
(0.064)\end{array}$ & $\begin{array}{l}-0.078 \\
(0.122)\end{array}$ & $\begin{array}{l}-0.008 \\
(0.091)\end{array}$ \\
\hline Upperclass $\times$ Only-boys school & & & & $\begin{array}{l}-0.486 \\
(0.457)\end{array}$ & $\begin{array}{l}-0.527 \\
(0.765)\end{array}$ & $\begin{array}{c}-1.326^{* * *} \\
(0.361)\end{array}$ \\
\hline Upperclass $\times$ Only-girls school & & & & $\begin{array}{l}-0.331 \\
(0.405)\end{array}$ & $\begin{array}{c}0.177 \\
(1.005)\end{array}$ & $\begin{array}{l}-0.001 \\
(0.294)\end{array}$ \\
\hline Upperclass $\times$ Coeducational school & & & & $\begin{array}{l}-0.351 \\
(0.428)\end{array}$ & $\begin{array}{c}-0.390 \\
(0.746)\end{array}$ & $\begin{array}{c}0.000 \\
(0.288)\end{array}$ \\
\hline Upperclass $\times$ PSU math & & & & $\begin{array}{l}0.001^{*} \\
(0.000)\end{array}$ & $\begin{array}{c}0.002^{* *} \\
(0.001)\end{array}$ & $\begin{array}{c}0.000 \\
(0.001)\end{array}$ \\
\hline Upperclass $\times$ High school GPA & & & & $\begin{array}{l}-0.000 \\
(0.001)\end{array}$ & $\begin{array}{c}0.000 \\
(0.001)\end{array}$ & $\begin{array}{l}-0.001 \\
(0.001)\end{array}$ \\
\hline Upperclass $\times$ Missing PSU and High school GPA & & & & $\begin{array}{c}0.523 \\
(0.523) \\
\end{array}$ & $\begin{array}{c}1.633^{* *} \\
(0.798)\end{array}$ & $\begin{array}{l}-0.306 \\
(0.564) \\
\end{array}$ \\
\hline Observations & 3358 & 1651 & 1707 & 3358 & 1651 & 1707 \\
\hline
\end{tabular}

Notes: The sample includes students enrolled in first year in years 2017 and 2018 and students enrolled in years 2 to 6 who were surveyed in 2017, 2018 and 2019. All columns include university dummies. Standard errors, clustered at the university/major level, are pr $\$ 2$ ented in parentheses. ${ }^{* * *},{ }^{* *}$ and $*$ indicate statistical significance at the $99 \%, 95 \%$ and $90 \%$, respectively. 
Table A-6: Are economic students more sexist than other students? - Adjusting for multiple hypotheses testing

\begin{tabular}{|c|c|c|c|c|}
\hline \multirow[t]{2}{*}{ Sample: } & \multicolumn{2}{|c|}{ All students } & \multirow{2}{*}{$\begin{array}{c}\text { Male } \\
(3)\end{array}$} & \multirow{2}{*}{$\begin{array}{c}\text { Female } \\
(4)\end{array}$} \\
\hline & $(1)$ & $(2)$ & & \\
\hline \multirow[t]{2}{*}{ IATscience } & 0.127 & 0.050 & -0.046 & 0.184 \\
\hline & {$[0.201]$} & {$[0.551]$} & {$[0.792]$} & {$[0.405]$} \\
\hline \multirow[t]{2}{*}{ IATcareer } & 0.170 & 0.145 & 0.231 & 0.054 \\
\hline & {$[0.000]$} & {$[0.000]$} & {$[0.000]$} & [0.608] \\
\hline \multirow[t]{2}{*}{ Hostile } & 0.169 & 0.147 & 0.157 & 0.146 \\
\hline & [0.402] & {$[0.047]$} & {$[0.068]$} & [0.129] \\
\hline \multirow[t]{2}{*}{ Benevolent } & 0.194 & 0.152 & 0.153 & 0.157 \\
\hline & {$[0.180]$} & {$[0.026]$} & [0.169] & {$[0.041]$} \\
\hline \multirow[t]{2}{*}{ Roles: traditional } & 0.089 & 0.057 & 0.074 & 0.063 \\
\hline & {$[0.505]$} & {$[0.551]$} & [0.392] & [0.608] \\
\hline \multirow[t]{2}{*}{ Roles: normative } & 0.181 & 0.110 & 0.119 & 0.114 \\
\hline & {$[0.086]$} & {$[0.049]$} & [0.169] & {$[0.179]$} \\
\hline \multirow[t]{2}{*}{ Math } & 0.152 & 0.102 & 0.168 & 0.075 \\
\hline & [0.093] & {$[0.335]$} & [0.169] & {$[0.424]$} \\
\hline \multirow[t]{2}{*}{ Discrimination } & 0.012 & -0.012 & -0.012 & -0.015 \\
\hline & {$[0.853]$} & {$[0.794]$} & {$[0.856]$} & {$[0.714]$} \\
\hline \multirow[t]{2}{*}{ Skill and preferences } & 0.102 & 0.105 & 0.089 & 0.114 \\
\hline & {$[0.402]$} & {$[0.137]$} & {$[0.244]$} & {$[0.424]$} \\
\hline \multirow{2}{*}{$\begin{array}{l}\text { Observations Score } \\
\text { Controls }\end{array}$} & 3,428 & 3,358 & 1,651 & 1,707 \\
\hline & no & yes & yes & yes \\
\hline
\end{tabular}

Notes: The sample includes students enrolled in first year in years 2017 and 2018 and students enrolled in years 2 to 6 who were surveyed in 2017, 2018 and 2019. Column 1 shows the mean of each dependent variable for B\&E students students and Column 2 shows the mean for students in other fields. In columns 3-6, each coefficient comes from a separate regression of the dependent variable on a dummy for whether the student is enrolled in B\&E. Controls are female, dummies for mother's education, working mother, school type (private, public, voucher), education type (mixed, single-sex school, single-sex classroom), highschool GPA, college admission test scores (PSU) and university dummies. Standard errors, clustered at the university/major level, are presented in parentheses. ${ }^{* * *}, * *$ and $*$ indicate statistical significance at the $99 \%, 95 \%$ and $90 \%$, respectively. 
Table A-7: Economics and gender biases, selection or treatment effect? - Adjusting for multiple hypotheses testing

\begin{tabular}{|c|c|c|c|c|c|c|c|c|c|}
\hline \multirow[b]{2}{*}{ Sample: } & \multicolumn{3}{|c|}{ All students } & \multicolumn{3}{|c|}{ Male students } & \multicolumn{3}{|c|}{ Female students } \\
\hline & $\begin{array}{l}\text { First year } \\
\text { (1) }\end{array}$ & $\begin{array}{l}\text { Upperclass } \\
(2)\end{array}$ & $\begin{array}{l}\text { Dif-in-Dif } \\
\text { (3) }\end{array}$ & $\begin{array}{c}\text { First year } \\
\text { (4) }\end{array}$ & $\begin{array}{c}\text { Upperclass } \\
(5)\end{array}$ & $\begin{array}{l}\text { Dif-in-Dif } \\
\quad(6)\end{array}$ & $\begin{array}{l}\text { First year } \\
\text { (7) }\end{array}$ & $\begin{array}{l}\text { Upperclass } \\
\text { (8) }\end{array}$ & $\begin{array}{l}\text { Dif-in-Dif } \\
(9)\end{array}$ \\
\hline \multirow[t]{2}{*}{ IATscience } & 0.037 & 0.065 & 0.028 & -0.055 & -0.053 & 0.002 & 0.141 & 0.243 & 0.102 \\
\hline & {$[0.778]$} & {$[0.546]$} & {$[0.996]$} & {$[0.686]$} & {$[0.715]$} & {$[0.981]$} & {$[0.711]$} & {$[0.463]$} & {$[0.979]$} \\
\hline \multirow{2}{*}{ IATcareer } & 0.081 & 0.193 & 0.112 & 0.188 & 0.263 & 0.075 & -0.036 & 0.119 & 0.155 \\
\hline & {$[0.546]$} & {$[0.000]$} & {$[0.716]$} & {$[0.487]$} & {$[0.004]$} & {$[0.970]$} & {$[0.941]$} & {$[0.603]$} & {$[0.946]$} \\
\hline \multirow[t]{2}{*}{ Hostile } & 0.146 & 0.168 & 0.022 & 0.122 & 0.222 & 0.100 & 0.161 & 0.149 & -0.013 \\
\hline & [0.103] & {$[0.101]$} & [0.997] & {$[0.487]$} & {$[0.030]$} & {$[0.849]$} & {$[0.074]$} & {$[0.463]$} & {$[0.996]$} \\
\hline \multirow[t]{2}{*}{ Benevolent } & 0.123 & 0.192 & 0.069 & 0.066 & 0.263 & 0.197 & 0.178 & 0.145 & -0.034 \\
\hline & {$[0.324]$} & {$[0.002]$} & {$[0.838]$} & {$[0.643]$} & {$[0.004]$} & {$[0.097]$} & {$[0.073]$} & {$[0.433]$} & {$[0.996]$} \\
\hline \multirow[t]{2}{*}{ Roles: traditional } & 0.061 & 0.070 & 0.009 & 0.072 & 0.113 & 0.040 & 0.072 & 0.054 & -0.018 \\
\hline & {$[0.614]$} & {$[0.546]$} & [0.997] & {$[0.487]$} & {$[0.365]$} & {$[0.970]$} & [0.859] & {$[0.742]$} & {$[0.996]$} \\
\hline \multirow[t]{2}{*}{ Roles: normative } & 0.115 & 0.137 & 0.022 & 0.089 & 0.170 & 0.081 & 0.152 & 0.124 & -0.029 \\
\hline & {$[0.022]$} & {$[0.285]$} & [0.997] & {$[0.487]$} & {$[0.244]$} & {$[0.919]$} & {$[0.076]$} & {$[0.475]$} & {$[0.996]$} \\
\hline \multirow[t]{2}{*}{ Math } & 0.072 & 0.135 & 0.063 & 0.144 & 0.195 & 0.052 & 0.019 & 0.126 & 0.107 \\
\hline & {$[0.138]$} & {$[0.484]$} & {$[0.970]$} & {$[0.088]$} & {$[0.346]$} & {$[0.967]$} & {$[0.941]$} & {$[0.475]$} & {$[0.968]$} \\
\hline \multirow{2}{*}{ Discrimination } & -0.030 & 0.014 & 0.044 & -0.094 & 0.069 & 0.164 & 0.022 & -0.023 & -0.045 \\
\hline & {$[0.778]$} & {$[0.811]$} & {$[0.980]$} & {$[0.487]$} & {$[0.715]$} & {$[0.350]$} & [0.941] & {$[0.742]$} & {$[0.996]$} \\
\hline \multirow[t]{2}{*}{ Skill and preferences } & 0.119 & 0.116 & -0.003 & 0.124 & 0.066 & -0.058 & 0.089 & 0.147 & 0.059 \\
\hline & {$[0.360]$} & {$[0.305]$} & {$[0.997]$} & {$[0.487]$} & {$[0.715]$} & {$[0.970]$} & {$[0.867]$} & {$[0.475]$} & {$[0.996]$} \\
\hline \multirow{2}{*}{$\begin{array}{l}\text { Observations Score } \\
\text { Controls }\end{array}$} & 1556 & 1802 & 3358 & 772 & 879 & 1651 & 784 & 923 & 1707 \\
\hline & yes & yes & yes & yes & yes & yes & yes & yes & yes \\
\hline
\end{tabular}

Notes: First year includes students enrolled in first year in years 2017 and 2018, while Upperclass includes students enrolled in years 2 to 6 who were surveyed in 2017, 2018 and 2019. In columns 1, 2, 4, 5, 7 and 8, each coefficient comes from a separate regression of the dependent variable on a dummy for whether the student is enrolled in Business \& Economics (B\&E). In columns 3, 6 and 9 each coefficient comes from a separate regression of the dependent variable on the interaction of B\&E and an indicator of Upperclass. Controls are female, dummies for mother's education, working mother, school type (private, public, voucher), education type (mixed, single-sex school, single-sex classroom), highschool GPA, college admission test scores (PSU) and university dummies. Standard errors, clustered at the university/major level, are presented in parentheses. ${ }^{* * *},{ }^{* *}$ and $*$ indicate statistical significance at the $99 \%, 95 \%$ and $90 \%$, respectively. 
Table A-8: Gender Bias and Economics - Panel Data - Adjusting for multiple hypotheses testing

\begin{tabular}{|c|c|c|c|c|c|c|c|c|c|}
\hline \multirow[b]{2}{*}{ Sample: } & \multicolumn{5}{|c|}{ All } & \multicolumn{2}{|c|}{ Men } & \multicolumn{2}{|c|}{ Women } \\
\hline & $\begin{array}{c}\text { 1st year } \\
\text { (1) }\end{array}$ & $\begin{array}{l}\text { 2nd Year } \\
(2)\end{array}$ & $\begin{array}{c}\mathrm{DiD} \\
(3)\end{array}$ & $\begin{array}{c}\text { DiD-FD } \\
(4)\end{array}$ & $\begin{array}{c}\text { Heckman } \\
(5)\end{array}$ & $\begin{array}{c}\text { DiD-FD } \\
(6)\end{array}$ & $\begin{array}{c}\text { Heckman } \\
(7)\end{array}$ & $\begin{array}{c}\text { DiD-FD } \\
(8)\end{array}$ & $\begin{array}{c}\text { Heckman } \\
(9)\end{array}$ \\
\hline \multirow[t]{2}{*}{ IATscience } & 0.032 & -0.022 & -0.054 & 0.004 & -0.052 & 0.016 & -0.069 & -0.108 & -0.118 \\
\hline & {$[0.944]$} & {$[0.968]$} & {$[0.969]$} & {$[0.986]$} & {$[0.747]$} & {$[0.972]$} & {$[0.949]$} & {$[0.881]$} & {$[0.982]$} \\
\hline \multirow[t]{2}{*}{ IATcareer } & 0.298 & 0.030 & -0.268 & 0.179 & -0.182 & 0.042 & 0.103 & 0.296 & 0.106 \\
\hline & {$[0.022]$} & {$[0.968]$} & {$[0.195]$} & {$[0.714]$} & {$[0.717]$} & {$[0.972]$} & {$[0.929]$} & {$[0.515]$} & {$[0.982]$} \\
\hline \multirow[t]{2}{*}{ Hostile } & 0.011 & 0.078 & 0.067 & 0.043 & 0.183 & 0.094 & 0.204 & -0.003 & 0.065 \\
\hline & {$[0.964]$} & {$[0.712]$} & {$[0.820]$} & {$[0.956]$} & {$[0.336]$} & {$[0.776]$} & {$[0.426]$} & {$[0.988]$} & {$[0.982]$} \\
\hline \multirow[t]{2}{*}{ Benevolent } & -0.009 & 0.143 & 0.153 & 0.057 & 0.156 & 0.244 & 0.328 & -0.109 & -0.072 \\
\hline & {$[0.964]$} & {$[0.302]$} & {$[0.195]$} & {$[0.956]$} & {$[0.279]$} & {$[0.518]$} & {$[0.183]$} & {$[0.768]$} & {$[0.973]$} \\
\hline \multirow[t]{2}{*}{ Roles: traditional } & -0.018 & -0.045 & -0.026 & -0.134 & -0.051 & -0.199 & -0.097 & -0.079 & 0.005 \\
\hline & {$[0.936]$} & {$[0.844]$} & {$[0.948]$} & {$[0.124]$} & {$[0.657]$} & {$[0.226]$} & {$[0.770]$} & {$[0.768]$} & {$[0.982]$} \\
\hline \multirow[t]{2}{*}{ Roles: normative } & 0.048 & 0.036 & -0.012 & -0.179 & -0.092 & -0.053 & -0.004 & -0.295 & -0.188 \\
\hline & {$[0.904]$} & {$[0.915]$} & [0.969] & {$[0.724]$} & {$[0.717]$} & {$[0.972]$} & {$[0.976]$} & {$[0.515]$} & {$[0.785]$} \\
\hline \multirow[t]{2}{*}{ Math } & 0.084 & 0.224 & 0.140 & 0.130 & 0.204 & 0.076 & 0.106 & 0.219 & 0.365 \\
\hline & {$[0.312]$} & {$[0.158]$} & [0.195] & {$[0.278]$} & {$[0.021]$} & {$[0.709]$} & {$[0.534]$} & {$[0.515]$} & {$[0.075]$} \\
\hline \multirow[t]{2}{*}{ Discrimination } & -0.208 & 0.083 & 0.291 & 0.229 & 0.318 & 0.183 & 0.335 & 0.248 & 0.294 \\
\hline & {$[0.127]$} & {$[0.832]$} & {$[0.195]$} & {$[0.066]$} & {$[0.000]$} & {$[0.383]$} & {$[0.161]$} & {$[0.205]$} & {$[0.145]$} \\
\hline \multirow[t]{2}{*}{ Skill and preferences } & -0.119 & 0.058 & 0.177 & 0.220 & 0.280 & 0.221 & 0.299 & 0.217 & 0.074 \\
\hline & {$[0.312]$} & {$[0.915]$} & {$[0.326]$} & {$[0.151]$} & {$[0.110]$} & {$[0.181]$} & {$[0.181]$} & {$[0.515]$} & {$[0.982]$} \\
\hline Controls & yes & yes & yes & no & no & no & no & no & no \\
\hline Student FE & no & no & no & yes & yes & yes & yes & yes & yes \\
\hline
\end{tabular}

Notes: First year includes students enrolled in first year in years 2017 and 2018, while Second year includes students enrolled in second year who were surveyed in 2018 and 2019. In columns 1 and 2, each coefficient comes from a separate regression of the dependent variable on a dummy for whether the student is enrolled in Business \& Economics (B\&E). In columns 3-9 each coefficient comes from a separate regression of the dependent variable on the interaction of B\&E and an indicator of Upperclass. Columns 4, 6 and 8 are estimated in first differences. In columns 5, 7 and 9, we use a heckman selection model to correct for attrition bias in the model with student fixed effect. Variables included in the selection model are a dummy for whether the student is enrolled in Business \& Economics (B\&E), the score in either wave 0 or 3 , and a dummy for whether the student gave their contact phone in addition to their contact email. Controls are female, dummies for mother's education, working mother, school type (private, public, voucher), education type (mixed, single-sex school, single-sex classroom), highschool GPA, college admission test scores (PSU) and university dummies. Standard errors, clustered at the university/major level, are presented in parentheses. $* * *, * *$ and $*$ indicate statistical significance at the $99 \%, 95 \%$ and $90 \%$, respectively. 


\section{Additional Figures}

Figure A-1

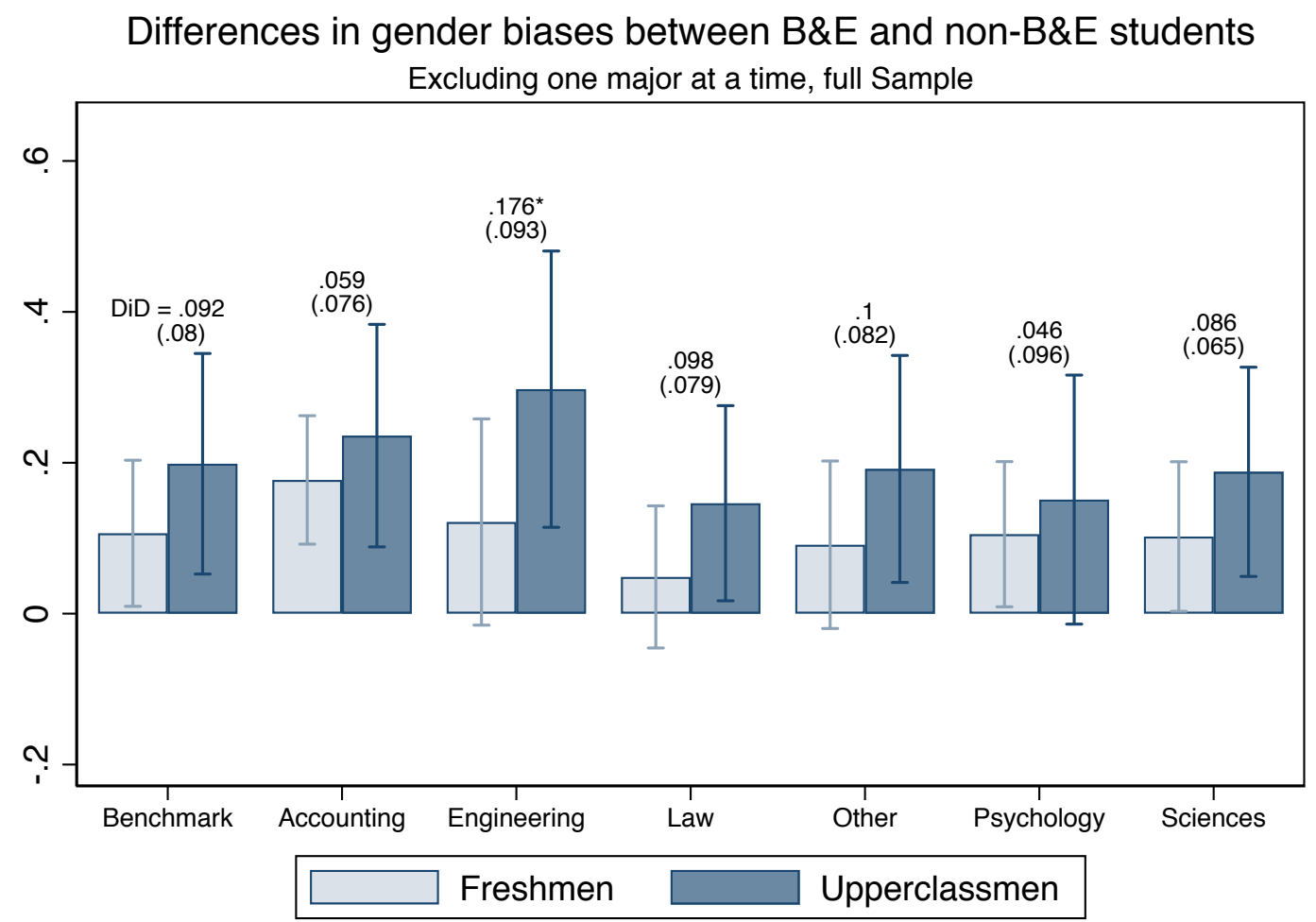

Notes: The figure shows estimates of studying B\&E on the aggregate sexism score, for first years (left bar), upperclassmen (right bar), and the interaction of studying B\&E and upperclass (indicated as DiD). Standard errors, clustered at the university/major level, are presented in parentheses. Benchmark corresponds to results where all other majors in the sample are included as controls, as in Table 7a. The other bars show results where one major is excluded from the control group. ${ }^{* * *},{ }^{* *}$ and $*$ indicate statistical significance at the $99 \%, 95 \%$ and $90 \%$, respectively. 


\section{Figure A-2}

\section{Differences in gender biases between B\&E and non-B\&E students}

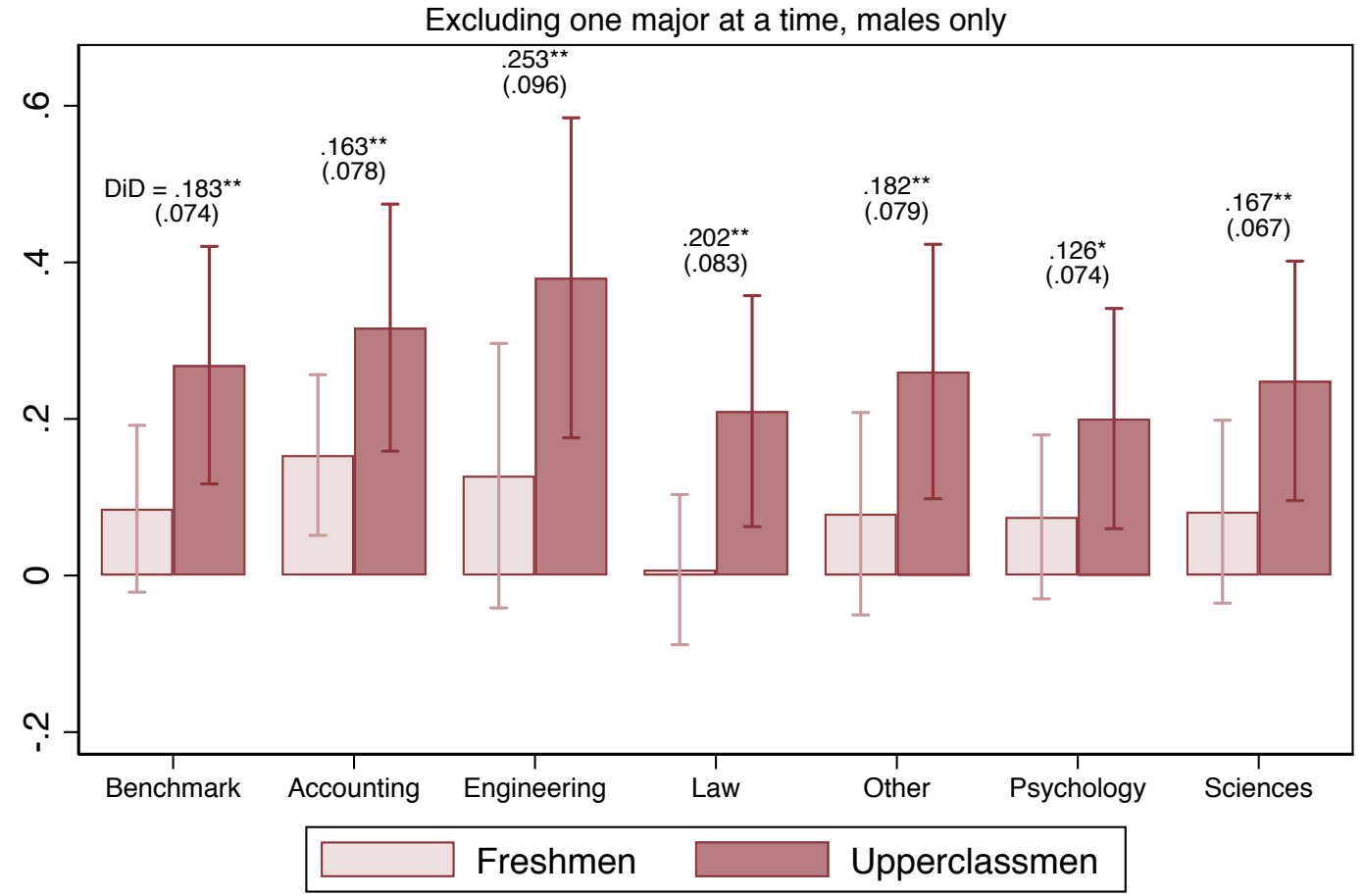

Notes: The figure shows estimates of studying B\&E on the aggregate sexism score, for first years (left bar), upperclassmen (right bar), and the interaction of studying B\&E and upperclass (indicated as DiD). Standard errors, clustered at the university/major level, are presented in parentheses. Benchmark corresponds to results where all other majors in the sample are included as controls, as in Table 7a. The other bars show results where one major is excluded from the control group. ${ }^{* * *},{ }^{* *}$ and ${ }^{*}$ indicate statistical significance at the $99 \%, 95 \%$ and $90 \%$, respectively. 


\section{Figure A-3}

\section{Differences in gender biases between B\&E and non-B\&E students}

\section{Excluding one major at a time, females only}

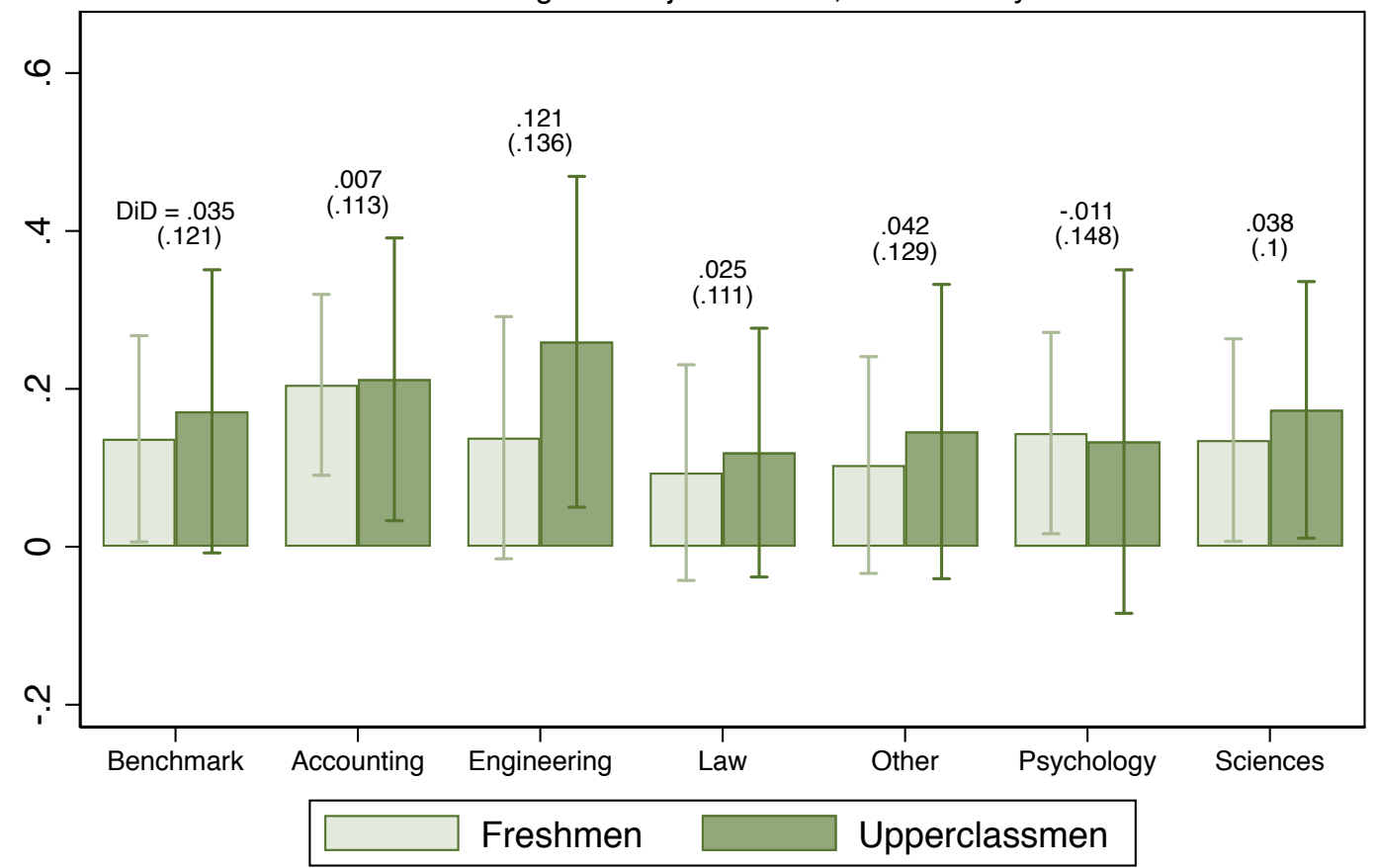

Notes: The figure shows estimates of studying B\&E on the aggregate sexism score, for first years (left bar), upperclassmen (right bar), and the interaction of studying B\&E and upperclass (indicated as DiD). Standard errors, clustered at the university/major level, are presented in parentheses. Benchmark corresponds to results where all other majors in the sample are included as controls, as in Table 7a. The other bars show results where one major is excluded from the control group. ${ }^{* * *},{ }^{* *}$ and ${ }^{*}$ indicate statistical significance at the $99 \%, 95 \%$ and $90 \%$, respectively. 